Florida International University FIU Digital Commons

\title{
Economic assessment of best management practices in the Mara River Basin : toward implementing payment for watershed services
}

George Atisa

Florida International University

DOI: $10.25148 /$ etd.FI14032367

Follow this and additional works at: https://digitalcommons.fiu.edu/etd

Part of the Environmental Sciences Commons

\section{Recommended Citation}

Atisa, George, "Economic assessment of best management practices in the Mara River Basin : toward implementing payment for watershed services" (2009). FIU Electronic Theses and Dissertations. 1333.

https://digitalcommons.fiu.edu/etd/1333 
FLORIDA INTERNATIONAL UNIVERSITY

Miami, Florida

ECONOMIC ASSESSMENT OF BEST MANAGEMENT PRACTICES IN THE

MARA RIVER BASIN: TOWARD IMPLEMENTING PAYMENT FOR WATERSHED

SERVICES

A thesis submitted in partial fulfillment of the

requirements for the degree of

MASTER OF SCIENCE

in

ENVIRONMENTAL STUDIES

by

George Atisa

2009 
To: Dean Kenneth Furton

College of Arts and Sciences

This thesis, written by George Atisa, and entitled Economic Assessment of Best Management Practices in the Mara River Basin: Toward Implementing Payment for Watershed Services, having been approved in respect to style and intellectual content, is referred to you for judgment.

We have read this thesis and recommend that it be approved.

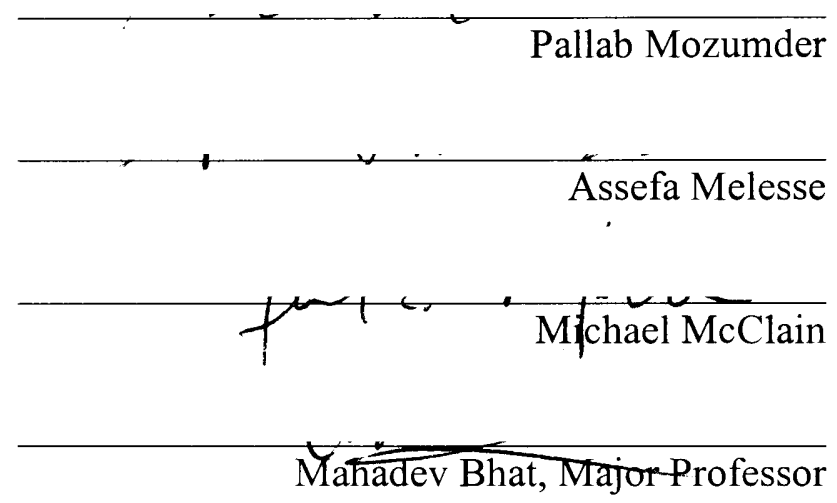

Date of Defense: May 8, 2009

The thesis of George Atisa is approved.

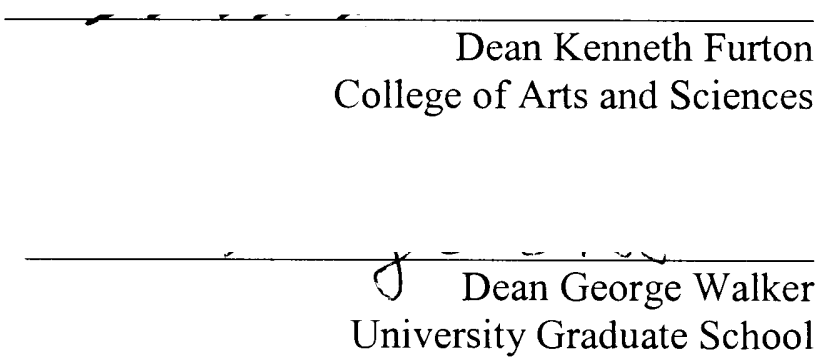

Florida International University, 2009 


\section{DEDICATION}

My wife Eucabeth Abuya and my children Andrew, Mathew and Linda Atisa. They have been my source of love, strength and inspiration. 


\section{ACKNOWLEDGMENTS}

I sincerely want to thank Dr. Mahadev Bhat for his professional guidance, advice and giving direction from the start of the survey to seeing me through this thesis. A special thank you to Dr. Michael McClain who in addition to serving in my committee, provided valuable support and funding through the Global Water for Sustainability (GLOWS) for my studies. Coming to Florida International University has tremendously

enriched my career. A sincere thank you to Dr. Assefa Melesse and Dr. Pallab Mozumder for agreeing to serve in my committee and helped me with valuable inputs throughout the time I was writing this thesis.

Thank you too to United States Agency for International Development through (GLOWS) for funding this research. My appreciation also to World Wildlife Fund (WWF) Eastern Africa Regional Programme Office, their field offices in Nakuru and Narok for their time and support while traveling in the Mara River Basin.

I would like to thank Mr. John Serut, the chair of the Mara River Basin stakeholders committee for all his support during the survey. Thank you to the farmers in the Mara River Basin for agreeing to fill out my very long and detailed questionnaires and for providing all the much needed background information.

Finally, thank you to my wife Eucabeth, my children Andrew, Mathew and Linda for all their support. I sincerely appreciate my parents for their prayers and all my friends who have been a source of inspiration throughout my stay at FIU. 


\author{
ABSTRACT OF THE THESIS \\ ECONOMIC ASSESSMENT OF BEST MANAGEMENT PRACTICES IN THE \\ MARA RIVER BASIN: TOWARD IMPLEMENTING PAYMENT FOR WATERSHED \\ SERVICES \\ by \\ George Atisa \\ Florida International University, 2009 \\ Miami, Florida \\ Professor Mahadev Bhat, Major Professor
}

The Mara River in East Africa is currently experiencing poor water quality and increased fluctuations in seasonal flow. This study investigated technically effective and economically viable Best Management Practices for adoption in the Mara River Basin of Kenya that can stop further water resources degradation.

A survey of 155 farmers was conducted in the upper catchment of the Kenyan side of the river basin. Farmers provided their assessment of BMPs that would best suit their farm in terms of water quality improvement, economic feasibility, and technical suitability. Cost data on different practices from farmers and published literature was collected. The results indicated that erosion control structures and runoff management practices were most suitable for adoption. The study estimated the total area that would be improved to restore water quality and reduce further water resources degradation. Farmers were found to incur losses from adopting new practices and would therefore require monetary support. 
1. INTRODUCTION .................................................... 1

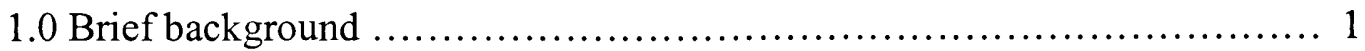

1.1 Statement of the problem ............................................. 3

1.2 Best Management Practices .............................................. 4

1.3 Payment for Watershed Services ........................................ 5

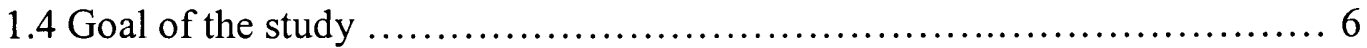

1.5 Research objectives ........................................................... 6

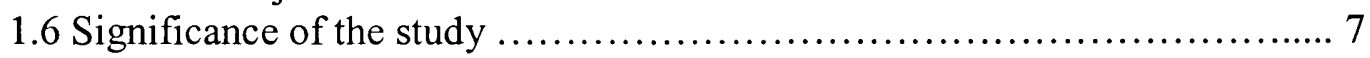

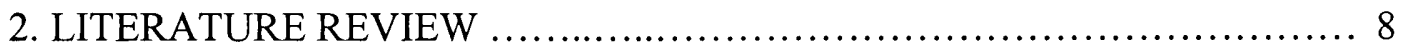

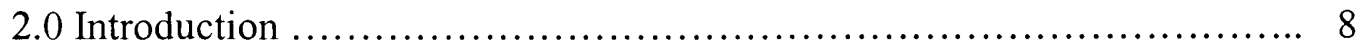

2.1 People and the economy in environmental context .................... 9

2.2 Constraints towards adoption of BMPs .............................. 11

2.3 Opportunity costs of BMPs Implementation .......................... 12

2.3.1 Land use, BMPs adoption and social opportunity costs ............... 13

2.3.2 Perception on expected returns and BMP attributes .................. 14

2.4 Estimation of the value of watershed services ........................ 14

2.5 Incentive based conservation practices ............................... 16

2.6 Key aspects of Payment for Watershed Services ...................... 17

2.7 Sustainable Water Resources Management ............................ 18

2.8 Water resources management policies in Kenya ....................... 20

2.9 Land use policies in Kenya ....................................... 21

2.10 Relationship between forest conservation and water resources .......... 23

3. SURVEY AND METHODOLOGY .................................. 24

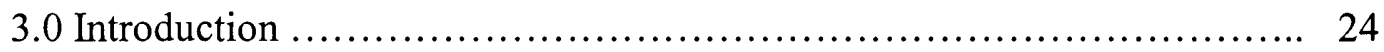

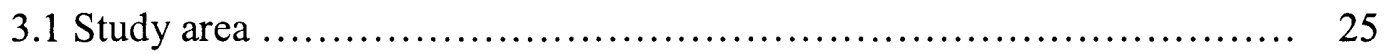

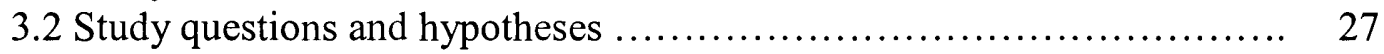

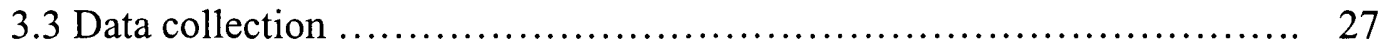

3.4 Perceptions and knowledge ...................................... 30

3.5 The description of Best Management Practices ....................... 30

3.6 Ranking of Best Management Practices ............................... 33

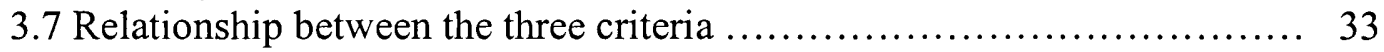

3.8 Opportunity cost of implementing Best Management Practices ............. 34

3.8.1 Opportunity costs estimation method .............................. 35

3.8.2 Estimation of the Net Present Value opportunity cost of BMPs adoption ....................................................... 36

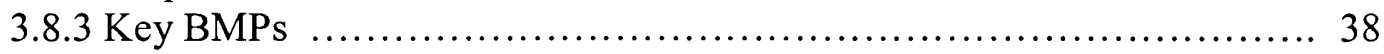

3.8.4 Implementation of erosion control practices ........................ 38

3.8.5 Implementation of crop nutrient management systems ................. 39

3.8.6 Implementation of Streamside Management Zones .................... 41 
3.8.7 Implementation of do-no-farming practices ....................... 42

3.8.8 Implementation of no-till farming practices ........................... 43

3.9 Sensitivity Analysis ................................................ 44

3.10 Estimation of land that need to be placed under BMPs ................. 46

3.11 Determining Payment for Watershed Services .......................... 48

3.12 Limitations of the methodology .................................... 49

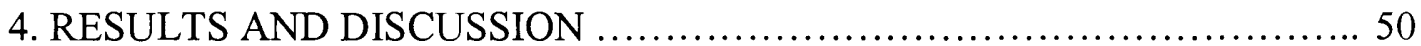

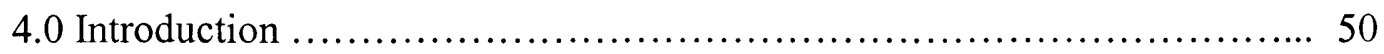

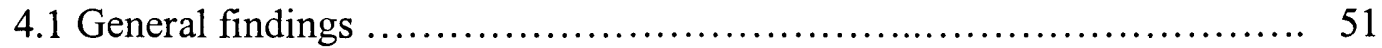

4.2 Sample characteristics ............................................. 52

4.2.1 Perceptions of farmers on status of water resources ..................... 53

4.2.2 Perception on methods for implementation of BMPs ................. 55

4.3 Ranking of BMPs across the three criterion .......................... 57

4.3.1 Highest and lowest ranked BMPs across all criteria $\ldots \ldots \ldots \ldots \ldots \ldots \ldots . \ldots 59$

4.3.2 Ranking of BMPs for water quality improvement .................... 59

4.3.3 Ranking of BMPs for economic feasibility ......................... 60

4.3.4 Ranking of BMPs for technical suitability ........................ 61

4.3.5 Relationship between the three criteria ........................... 61

4.5 Economics of implementing BMPs ................................ 62

4.6 Adoption of erosion control Best Management Practices ................. 63

4.6.1 Net Present Value opportunity costs of adoption of bench terraces ..... 63

4.6.2 Net Present Value opportunity costs of adoption of grass strips ......... 67

4.6.3 Net Present Value opportunity costs of adoption of crop nutrient management practices - Agro-forestry ............................. 69

4.6.4 Net Present Value opportunity costs of adoption of SMZ ............. 71

4.6.5 Net Present Value opportunity costs of adoption of do no farming ........... 73

4.6.6 Net Present Value opportunity costs of adoption of no till farming ....... 76

4.7 Sensitivity analysis ............................................... 79

4.8 Total amount of land to be placed under BMPs ....................... 84

4.9 Payment for Watershed Services ................................ 86

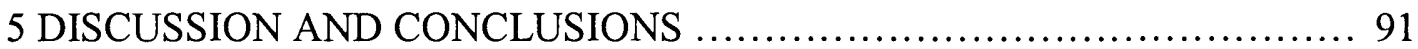

5.0 Introduction ..................................................... 91

5.1 Payment for Watershed Services ..................................... 92

5.2 Drivers of watershed degradation .................................... 92

5.2.2 Role of economic incentives ...................................... 94

5.2.3 Selection of BMPs for water quality improvement .................... 96

5.2.4 How the watershed can be better protected .......................... 96

5.3.0 Expected impacts of BMPs and PWS on the downstream communities ... 97

5.3.1 Opportunity costs of adoption of BMPs ............................ 98

5.3 .2 Sensitivity Analysis ............................................... 99

5.3.3 Total area to be placed under BMPs .............................. 100

5.3.4 Estimation of PWS ............................................ 102

5.4 Institutional Mechanisms for PWS .............................. 103 
5.5 Financing PWS 


\section{LIST OF TABLES}

TABLE

PAGE

1. Brief description of Best Management Practices .......................... 31

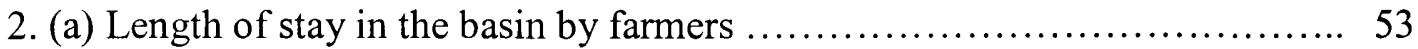

2. (b) Distribution of farm sizes and ownership .......................... 53

3. Perception of farmers on factors that affect water $\ldots \ldots \ldots \ldots \ldots \ldots \ldots \ldots \ldots \ldots \ldots \ldots$

4. Farmer's perception on methods of implementing BMPs ................. 57

5. Ranking of suitability of BMPs for the three criteria $\ldots \ldots \ldots \ldots \ldots \ldots \ldots \ldots . \ldots 58$

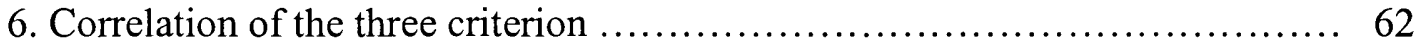

7. (a) Opportunity cost and Net Present Value of adoption of bench terraces ..... 66

7. (b) Opportunity cost and Net Present Value of adoption of grass strips ......... 68

8. Opportunity cost and Net Present Value of adoption of crop nutrient management practices - Agro-forestry ............................... 70

9. Opportunity cost and Net Present Value of adoption of Streamside Management Zones

10. Opportunity cost and Net Present Value of adoption of do no farming ........ 75

11. Opportunity cost and Net Present Value of adoption of no till farming ....... 78

12. Sensitivity Analysis of opportunity costs when costs vary but incomes are held constant

13. Sensitivity Analysis of opportunity costs when incomes vary but costs are held constant

14. Number of hectares that need to be placed under BMPs 86

15. Estimation of initial year Payment for Watershed Services using opportunity costs of the analyzed practices

16. (a) Opportunity costs per hectare at different cost values and constant incomes from farming 
16 (b) Opportunity costs per hectare at different income levels and constant farming and adoption costs 


\section{LIST OF FIGURES}

FIGURE

PAGE

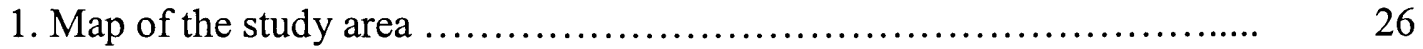

2. Ranking of BMPs on their effectiveness on water quality improvement .... 60

3. Ranking of BMPs on their economic feasibility ........................ 60

4. Ranking of BMPs on their technical suitability ........................ 61

5. Farmer's view on the most sustainable source of funding for PWS ....... 105 


\section{CHAPTER 1: INTRODUCTION}

\subsection{Brief Background}

Freshwater is often considered a free gift of nature to be used by humans, wild animals and birds. Watersheds are the main sources of freshwater supplies and provide other environmental services such as fertile agricultural lands, clean air, flood control and wildlife habitats. The demand for watershed services in many river basins worldwide far exceeds supply in terms of quantity and quality as a result of population growth and poverty. Watershed services are inherently public goods, do not require pay for access, and are therefore often undersupplied. The current trend of watershed deforestation and forest degradation worldwide, combined with the ever increasing demand for watershed services, requires that freshwater practices be re-evaluated, and payment policies implemented.

Payment for Watershed Services (PWS), also known as Payment for Environmental Services (PES), provides a structure to trade watershed services where upstream communities get paid by downstream communities for their provision. Payment for Watershed Services are essentially economic incentives used to compensate upstream communities for opportunity costs as they work to increase the quality and quantity of environmental services available to downstream communities. Opportunity costs arise as a result of change in land use practices from conventional towards environmentally sustainable practices. Use of PWS as an economic incentive allows upstream landowners to respond to the provision of watershed services in ways that benefit both the environment as well as the downstream communities.

Current farming practices in the upper and lower catchments in the Mara River 
Basin (MRB) of Kenya are primary factors contributing towards the reduction in quality and quantity of water in the basin (ENSDA, 2005). Existing water management approaches in Kenya have not been effectively applied in managing the cumulative effects of land uses and land management on water quality and quantity in watersheds.

Since 2000 , the Kenyan government has been working to decentralize water management responsibilities to local authorities (Water Act, 2000). However, the emerging institutions do not adequately address effects of land uses and land management on water quality and quantity in river basins, such as the Mara. The institutions lack financial resources, technical capacity and legal backing to enforce land use planning, regulate land developments, control water pollution and provide outreach and education to the farmers. Weak enforcement of mandatory conservation regulations and lack of respect for land use plans in the face of high levels of poverty give incentives to farmers to employ farming practices that are perceived to cost less and bring in maximum returns at the expense of the environment. The current practices directly benefit farmers to destroy watersheds through conversion of forest lands to farms, rather than to conserve natural resources. The need to devise approaches that are sustainable and can effectively reduce the negative impacts of farming on water resources, while at the same time allowing for adequate supply of watershed services, continue to grow, however, current policies and practices lack adequate institutional, structural and financial resources.

Despite the establishment of Water Users Associations and the ongoing strategies to create Catchment Management Advisory Committees in the MRB, no clear strategies exist from the stakeholders and the emerging institutions on how to address the negative 
agricultural impacts on water resources and the environment. In addition, the lack of structures exacerbate water problems in the MRB, as those that benefit from water resources can not directly invest in the management and protection of the watershed and water resources. A number of strategies that will allow farmers in the headwaters of the MRB to continue to use land resources without degrading the environment are available but would have to be negotiated and agreed to by all communities on how to implement them.

\subsection{Statement of the Problem}

The last decade has seen an upsurge in population migration to the basin comprised of mainly commercial and subsistence farmers and investors in the tourism sector (Gereta et al., 2002). This has come with increased demand for agricultural land, extraction of water for subsistence agriculture and domestic use, irrigation farming and the needs of the tourism sector. As a consequence, the watershed is experiencing very high deforestation rates leading to reduced amount of water flowing in the river during the dry season and severe negative impacts on water quality from sediments eroded from farms. The Mara river has its source in the Mau Forest Complex (MFC). Visual inspection conducted for this study in the MFC estimates natural vegetation cover to be approximately $30 \%$ of the area.

Past investigations have suggested that on-going deforestation on the watershed and increasing demand for water in the entire upper region of the basin have reduced the flows in the Mara River (Gereta et al., 2002). These developments, combined with the rapid population growth that now stands at over 3\% per year (ENSDA, 2005), points 
towards a situation where water demand will soon surpass the supply. Farmers upstream on the Mara River practice subsistence farming more than any other form of land-use (Mutie et al., 2006). In addition, a few large-scale farming operations use the basin, mainly for tea, dairy farming and wheat crops. Land leased by large-scale farmers increased from 18,000 hectares to 27,000 hectares in 1987 (Norton-Griffiths, 2002). Soil erosion from farming activities in the MRB is the greatest challenge to water quality problems (Mati et al., 2005). Studies done by World Wildlife Fund/Global Water for Sustainability (WWF/GLOWS) between 2005 and 2007 have found that the Mau Forest Complex (MFC) annually releases tons of sediments that contain nutrients into the Mara River.

Although many studies have examined the MRB, none have focused on the development and implementation of market principles and Best Management Practices (BMP) in the management of water resources. A void exists in the literature on the implementation of best management practices through market-based programs such as payment for watershed services. Land and water resources are still perceived to be relatively abundant in the upper part of the basin and therefore farming communities see little need to start employing BMPs on their farms. There is limited coordination and no mutually agreed beneficial resource use plans that address the current environmental and socio-economic needs for the communities that live in different parts of the basin.

\subsection{Best Management Practices}

Best Management Practices are management methods that provide for economic, environmental and agroeconomic efficiency in agriculture (Brown, 2003). They are 
effective, practical, structural or nonstructural methods that prevent or reduce soil erosion, watershed destruction, the movement of sediment, nutrients, pesticides and other pollutants from the land to surface or ground water, or which protect the quality of ecosystems from potential adverse effects of agricultural practices (Ching, 2001).

\subsection{Payment For Watershed Services}

A gradual shift from ineffective, mandatory or voluntary watershed management programs towards incentive-based policies in the protection of the environment has proven to be effective in many river basins worldwide (Wunder, 2005). Mechanisms such as the PWS offer alternative means of incomes to upstream farmers who would otherwise rely on agriculture alone for food and for family incomes. Under a PWS mechanism, either communities downstream in the basin, the government or other financial sources pay upstream farmers for the maintenance of land use that improves infiltration and reduces erosion and runoff of agrochemicals. Payment for Watershed Services provides a structure that enables beneficiaries of water resources to pay for their supply by creating financial resources that would go towards improvement of land resources in the upper section of the watershed.

Implementation of BMPs by all farmers in the upper part of the basin and payment by communities that live in the lower basin to invest towards such implementation of BMPs upstream is considered an innovative and sustainable way for water resource conservation (Moore, 2004). The Payment for Watershed Services creates incentives and raises revenues that motivate society into responsible use and conservation of water. Incentives improve relations and provide a sense of ownership and obligation between the upstream and downstream communities. Use of traditional command and 
control policies where there are no strong and clear enforcement mechanisms leaves resources vulnerable to abuse, misuse, and wasteful behavior by the society.

There is still much to be done for PWS to fulfill this role, and it is important to find the most acceptable, tangible and focused approach for the calculation of the payments. Many studies have attempted to value environmental services based on intangible variables that often are difficult to formulate within farmers' decision making processes. Farmers are more concerned with the opportunity cost of conservation, primarily what they can harvest from one hectare of land if it were cultivated (Moore, 2004). Implementation of BMPs provides the necessary tool upon which PWS can be designed (WWF, 2001). These payments are intended to reduce the burden of the supply of watershed services by upstream landowners so that conserving forests, reforestation and maintenance of land cover become more attractive than the agricultural alternatives such as clearing forests to plant maize, vegetables and potatoes (Nasi, Wunder \& Campos, 2002).

\subsection{Goal of the study}

The main goal of this study is to identify the most economical, acceptable and suitable Best Management Practices that would alleviate water problems in the Mara River Basin.

\subsection{Research objectives}

The primary objective of this study is to identify practices and costs, as well as find sustainable funding mechanisms for economically and technically suitable water and 
BMPs that are capable of restoring water flow and provide quality water in the Mara River Basin. Implementation of these practices may be achieved through adopting a PWS program under which those implementing BMPs would be appropriately compensated.

Specific objectives are:

I. Identify suitable sets of BMPs that ensure a sustained flow of Watershed Services in the MRB.

II. Analyze the costs of implementing BMPs for different farm systems in the MRB.

III. Identify sustainable, acceptable and cost effective funding mechanisms for the implementation of BMPs in the MRB.

\subsection{Significance of the study}

The declining water resources and quality degradation in East Africa has received growing attention. Identified during the survey are possible solutions that can be used to reverse the declining trends and improve the water quality. Implementation of BMPs with the aid of economic incentives as alternatives to command and control regulations is one of the solutions. Forces of economic development and rising poverty levels in most rural communities in Kenya tend to embrace worst agricultural practices that degrade environmental resources. Using economic incentives makes communities natural allies and partners in water resource conservation (Wunder, 2005). Implementing PWS schemes in the MRB will form a model of an incentive-based approach towards natural resources conservation in Kenya. 
Command and control regulations are viewed as denying communities opportunities for self determination to exploit natural resources for improving their socioeconomic wellbeing. The current study applies the concept of Payment for Environmental Services (PES) where upstream communities are compensated for implementing practices on their farms that help to improve water quality and quantity. Identifying the technical suitability and economical viability of the BMPs for improving both water quality and quantity is a specific research objective in this study. The identification of sustainable possible funding sources will help to instill confidence in those who expect to be paid as well as those who receive environmental benefits.

The outcomes of this study will be shared and made available to communities and conservation organizations in the MRB. This will assist in creating sustainable structures to be used in water resources management. While this study is confined to the MRB, it can provide important lessons for other river basins as well.

\section{CHAPTER 2: LITERATURE REVIEW}

\subsection{Introduction}

Before discussing identification, implementation and pricing of the different BMPs, this study has reviewed the literature on the effects of agricultural activities on the environment and also on human perceptions on conservation and the willingness to receive and to pay for watershed services. The reviewed literature helps identify constraints that have prevented farmers from adopting specific BMPs, as well as the gaps that exist in current scholarship. Literature on the need for BMPs and how these may be linked to the improvement of water quantity, quality and the general community 
wellbeing has also been reviewed.

\subsection{People and the economy in environmental context}

People's greater dependence on land based resources has led to different emerging external economic, political and social dynamics that have disrupted ecosystems in MRB. Population growth resulting in both poverty and the search for wealth in the form of additional agricultural land has exerted pressure on the water and forest resources thereby creating what is referred to as the tragedy of the commons (Hardin, 1998). There is increasing degradation of resources that are commonly held by communities as individuals try to maximize their gains partly because they bear no costs (Wunder, 2007). When communities migrate in search of land, the tenure security under the indigenous system is weakened thus the social taboos that regulate communal natural resources management ceases to exist (Spash et al., 2005).

Farmers living in the headwaters of the MRB are a good example of communities living upstream maximizing the use of common natural resources resulting in the degradation and reduction of these same resources for the downstream communities. There are currently no specific and well researched solutions recommended that would slow down the degradation of water resources in the upper watershed region of the MRB. The government has attempted to employ command and control practices that have failed to stop settlements and agricultural expansion into fragile and protected lands. At the same time, when trying to address the emerging water resource problems, the use of both command and control and economic value theories in general lack the strength on how to 
treat time, complexity, strong uncertainty, political systems, rights and social norms (Spash et al., 2005).

The Mara river waters are held commonly by numerous users at different levels within the basin who can be seen as internal and at the same time external depending on the tenure systems where they reside. The issue of water as common resource problem is treated differently by different groups of people residing in the basin. What happens to agriculture in the MFC complex determines what happens to water in terms of quantity and quality in the entire MRB. Economic considerations drive people in the direction where they build assumptions that are inconsistent with preservation of the environment for future needs (Spash et al., 2002).

Environmental quality and natural resources that are shared widely among different interest groups depend upon the efficient and sustainable management of the common water resources (Wunder, 2007). Water resource problems in the MRB and land use trends paint a picture where future water demand is anticipated to outstrip supply and create conflicts between the different users (Mati et al., 2005; Hoffman, 2007). There is increased pressure on water resources from a growing number of users that include loggers, subsistence farmers, irrigation farmers and the hotels and lodges that serve the tourism sector, leading to heightened levels of competition for the resource base (Hoffman, 2007).

Water resource supply is a land-resource-environment interaction (Hooper, 2003). There is often, however, no link between promotion of agricultural practices designed to protect water quality and the integration of the water quality protection programs into the decision making process of farmers (Kehrig, 2002). The economic prerequisite for water 
resource conservation therefore lies in incentives that enlist farmers in conservation practices (Wunder, 2008). Conserving land resources that improve watershed conditions must be made more attractive through the use of incentives. To do this, best land management must be translated into income and that this income be paid to upstream farmers as a reward for their conservation (Wunder, 2007).

\subsection{Constraints towards adoption of BMPs}

The perception about the role of BMPs in improving natural resources and reducing pollution from agriculture varies widely between different countries (Hilliard et al., 2002). While agricultural pollution problems are seen as very serious in some countries and some BMPs have found their way into legislative regulations governing farm practices (Hilliard et al., 2002), Kenya is still at its infant stage and many BMPs remain largely untested. Public attention remains more towards extractive agriculture and less to natural resource quality improvement and protection (Swinkels et al., 1996). Despite the common sense appeal that BMPs might have for farmers, their adoption rate remains low in Kenya (Swinkels et al., 1996).

When the cost of implementing a management practice is higher than the benefit that may accrue from that practice, then this may not be considered for adoption unless someone else pays for such costs (Coxe \& Hedrich, 2007). At the same time, if the cost is so low but the practice cannot meet the intended objective in a specific situation, adoption will not be necessary. There is, however, great potential in MRB of adoption of appropriate BMPs as there is already a greater willingness by downstream farmers to pay and a willingness by upstream communities to be compensated (Koji, 2008) 
Adoption of BMPs requires extra labor, land and capital and therefore often leads to reduced short-term profits for the farmers (FAO, 2005). In general, adoption of BMPs is a function of the characteristics of the type of BMP, perception of its economic advantages, as well as the availability and distribution of the factors of production (FAO, 2005). Rapid population growth in areas where farmers own an average of 2.4 hectares of land or less does not earn them extra revenues that can be used to invest in BMPs for waters resources improvement. In this kind of situation, farmers are increasingly under pressure to intensify and expand land use to try to meet their immediate basic needs (FAO, 2005). The economic benefits of adopting BMPs may not be apparent hence the tendency to hold onto conventional practices (Hilliard et al., 2002).

\subsection{Opportunity costs of BMPs Implementation}

Opportunity costs of land use changes and natural resources conservation in many places has not been given attention to match their economic importance in decision making (Panyotou, 1994). The use of economic incentives for conservation has therefore continued to be compromised as opportunity costs are not fully considered in the valuation of watershed services (Griffiths \& Southey, 1995). Net returns from agricultural incomes are used to estimate opportunity costs of change in land use (Griffiths \& Southey, 1995). These net returns are not strictly speaking net since they leave out the cost of land and show only returns to land rather than to capital (Griffiths \& Southey, 1995). Opportunity costs are a major influence on the net benefits of the farmers residing in the headwaters of the MRB. Increasing dependence on land due to limited employment opportunities and high rate of population growth exacerbates opportunity 
costs. Although the use of BMPs leads to increased profitability and production efficiency, most small scale farmers rarely view adoption of BMPs in these terms due to high opportunity costs (Bollinger et al, 2005).

A major objective of farmers is to maximize returns to labor and overall social and economic welfare (FAO, 2005). Even when financial incentives may appear attractive, consideration of non-financial factors to understand the actual potential of adoption should be explored (FAO, 2005). Adoption of some BMPs can easily change farm operations from labor intensive that is often readily available to use of technology that could be more expensive (Bollinger et al., 2005).

\subsubsection{Land use, BMPs adoption and social opportunity costs}

Several economic and social variables need to be considered before adopting new practices. Nature, quality of the land and the degree of poverty affects both the costs of removing land from its current uses and the potential improvement of water quantity and quality (Sohngen \& Nakao, 1999). Some of the new BMPs involve removing land from its current uses and therefore understanding the magnitude of opportunity cost is an important variable in decision making (Sohngen \& Nakao, 1999). Farmers in the MRB in both Kenya and Tanzania are willing to adopt BMPs to protect water resources (Koji, 2008). Best Management Practices are, however, much more needed at the source of the river than any other section of the basin as this is where land resources are being stretched beyond the bounds of what the catchment can provide.

According to studies conducted in Southern Africa by Bollinger et al. (2005), farming practices by small scale farmers, their needs and priorities are rarely transparent 
to outsiders and have to be viewed in a holistic context by going beyond purely financial incentives and technical criteria. In the estimation of opportunity cost and returns from land, the degree of poverty, risk adversity, gender roles for various tasks and institutional support are not often considered when attempting to adopt BMPs. Introduction of appropriate BMPs with due respect to bio-physical conditions of the area, climatic constraints on one hand and market opportunities and increased management needs on the other requires involvement by all stakeholders and should take full cognizance of indigenous skills and knowledge.

\subsubsection{Perception on expected returns and BMP attributes}

Farmer's perceptions on the attributes of BMPs and expected yields or incomes after implementation greatly influence the adoption potential (FAO, 2005). Some of the attributes that stand out in this respect according to FAO, include the comparative advantage of a specific BMP whereby consideration is not only on higher yields but also improved soils, economical in terms of adoption cost and improvement of the general environment (2005). Secondly, compatibility with previous and current practices is a major attribute as this requires more investments and land to turn around an old practice to a totally new one. Thirdly, a good BMP must be simple, should be easy to pre-test and its impact should be obvious and convincing. Finally, it should not pose any technical difficulties and misunderstanding to the farmers.

\subsection{Estimation of watershed services}

Estimation of the value of watershed services takes on two values; the existence 
and direct use values (Griffiths \& Southey, 1995). These two values also represent the preservation option to use the resource in the future, keep its existence regardless of personal use and the desire to pass the resource to descendants (Spash et al., 2005). The meaning of these values remains contentious and in order to address the increasingly evident notion that preferences are formed by different stakeholders and that they do not agree in methods of valuing environmental goods and services (Spash et al., 2005), more tangible methods such as compensation based on opportunity costs of conservation as has been used in this study would be more acceptable.

Spash et al. (2005), have described valuation methods intended to estimate the value of watershed services with an aim of selecting project options on the basis of their welfare impacts and environmental degradation. These valuations are more theoretical in nature and often face serious implementation challenges. The need to find alternative and more tangible methods such as use of costs and benefits that resource users incur to arrive at opportunity costs to be used as basis of determining the value of environmental services has been given more attention in this study. The use and implementation of BMPs is a more practical and tangible method of estimating opportunity costs of change from conventional to improved practices.

Poor communities tend to rely more on land for their livelihood due to lack of alternative livelihood options (Rietbergen et al., 2002). Economic development, water availability and rainfall amounts have been major determinants of settlement locations by farmers and land use intensity, (Orindi et al., 2005; Griffiths \& Southey, 1995). Rapid population growth in the headwaters of the MRB has not been matched by commensurate development of sustainable land use and agricultural practices due to poverty and lack of 
investment by resource users in conservation. Valuing watershed services can better secure external funding and build incentives for sustainable land use practices.

\subsection{Incentive based conservation practices}

The Kenyan government has continued to rely on command and control policies mainly in the form of evictions to protect the headwaters of the Mara River but this has not had any positive impact in stopping people from acquiring forest lands and converting them to farmlands (ENSDA, 2005). The watershed remains under intense pressure from illegal settlers, forest loggers and families who rely on the forest as a source of energy and firewood (Mutie et al., 2005). Incorporation of economic based approaches in the form of PWS facilitates the creation of market mechanisms that generates financial resources to be used as incentives for upstream communities to implement practices that will guarantee sustainable use of resources in the watershed. Incentives for the implementation of BMPs should be designed so that they go beyond the BMPs and help to maintain the practices when implemented (FAO, 2004).

Adoption of BMPs may affect farmer's incomes positively or negatively. Land is a limited resource that cannot easily be expanded. Best Management Practices that reduce this land or hinder farm operations cannot be adopted unless adequate incentives are provided (Haggblade \& Tembo, 2003). Human choices are found to be influenced in a predictable way by changes in economic incentives (Zhong, 2003). Chomba (2004) observes that good land management practices are likely to last only in places where the created incentives are accompanied by good general conditions such as improved marketing opportunities and increased non-agricultural employment opportunities. 
Farmers will do away with BMPs if this increases their costs or does not add value to their most preferred need.

Efforts to develop incentive based approaches to natural resources management are part of a global trend of institutional changes and partnership developments between communities in sustainable water resources management (FAO, 2004). Incentives would be used to reduce the operational costs of delivering water supplies and sanitation as well as the cost of conservation and poverty alleviation (FAO, 2004). The upper basin of the MRB is generally well supplied with water through rainfall, and as such is more vulnerable to population pressure. The lower basin receives scanty and unreliable rainfall and the shortfall is bridged by the Mara River. Adoption of BMPs at the upper basin is very crucial to sustain river flow, without which shortages occur downstream where huge amounts of water is required by large scale wheat farmers, pastoralists, small scale farmers, the wildlife and hotels and lodges that serve the tourism sector.

\subsection{Key aspects of Payment for Watershed Services}

The primary aspect is the willingness to pay (WTP) and the willingness to accept (WTA). According to Kahneman and Kversky (1979), people value gains and losses asymmetrically and therefore there is always a gap between WTP and WTA. Preferences are formed and often the value of watershed services has no consensus (Orindi \& Huggis, 2005). Managers of PWS need to understand the requirements of the providers of the services and those of the beneficiaries.

Payment for watershed services relies purely on economic incentives and can coexist with other forms of natural resource management schemes (Wunder, 2005). They 
integrate conservation and development concerns to achieve conservation by distraction, less poverty and less degradation effects (Wunder, 2005). They uphold a holistic approach that includes institutional capacity building and generate benefits to be used to buy local goodwill towards conservation. Under these schemes, local farmers need not be expelled and conservation buyers need not worry about enforcing land tenure an, important attribute for the MRB (Wunder, 2005).

According to Wunder (2005), local people convert forested lands to farmlands because it pays them to do so. When deciding on local land-use changes, an individual landowner has to make his or her own individual valuation exercise, to determine whether the net local benefits are superior to the best possible land-use alternative. However, unlike most farm and forest products, watershed service values are not paid for and therefore the economic value of services more often than not remains without a financial attachment such that those who own or control the flow of these services do not receive economic benefits that result from those services (Wunder, 2006). Owners of the land found upstream should be given incentives to be able to implement practices geared towards conservation generating benefits for downstream farmers (Wunder, 2006).

\subsection{Sustainable Water Resources Management}

Kenya is a water-scarce country with annual surface water potential estimated at only 19,590 million cubic meters and groundwater potential estimated at 619 million cubic meters (GoK, 2002). Over $80 \%$ of Kenya is arid and semi-arid and hence, the distribution of the available freshwater resources is limited in space and time (Water Act, 2002). With the increasing growth in national population and the subsequent socio- 
economic dynamics such as urbanization, tourism and agricultural activities, demand for water continues to rise. Current estimates indicate that only about $60 \%$ and $34 \%$ of the country's urban and rural populations, respectively, have access to safe drinking water (GoK, 2002).

The country is in its initial stages of identifying sustainable water resources management tools that can manipulate water producing systems to optimize long-term supply for both human and ecosystem needs (Hooper, 2003). Kenya lacks adequate financial resources to invest in this venture (Orindi \& Huggins, 2005). Water resources management have not moved towards the ecosystem approach where watersheds are seen as integrated ecological systems where human impacts on water are considered alongside other components that affect river basins (Wunder et al., 2007). This study has focused on the use of BMPs as these are components of land use that are known and understood by all stakeholders including social and environmental connections to land resources.

A combination of stakeholder participation, institutional development and inclusion of physical, biological and socio-economic dynamics in sustainable water resources management that forms the modern Integrated Water Resources Management (IWRM) needs to be brought down and adopted in the Mara. Integrated Water Resources Management (IWRM) takes into account cross sectoral coordinated approach to water resources management across time, space and river basin scale to find solutions to conflicts over use of the commonly shared resource, provide mechanisms for meeting top-down and bottom-up management. There is a missing link in the Integrated Water Resources Management in Kenya although there are ongoing developments towards the same and the different uses of water by both humans and ecosystem needs, and upstream- 
downstream relationships for efficient allocation of the resource (Hooper, 2003).

\subsection{Water resources management policies in Kenya}

Before the year 2000, the government of Kenya was directly involved in the provision and regulation of water supplies to all sectors. During this time, water management and supply service was wrought in corruption and inefficiencies. In 1999, a new water policy was launched where the government was to remain in the business of being a regulator and providing an enabling environment for water resources management (Water Act, 2000). The main actors in water resources management and development were to be the communities and the private sector only. The new policy call for the establishment of an efficient and effective framework for development and management of the water sector, development of sound and sustainable financial system, water supply and sanitation. Other policy developments required were the integrated approach to water resources management encouraging community participation and decentralized decision making to local levels (Water Act, 2000).

The policy changes that were being implemented in the year 2000 were aimed at strengthening local institutions, operationalization of the water Act, Number 8 of 2002 and to decentralize decision making from the central government to the local level where water is used (Water Act, 2000). The enactment of Act Number eight led to the establishment of the Water Resources Management Authority (WRMA), a body responsible for water management. The WRMA now has offices at local level where communities influence decisions on how water should be managed (WWF, 2009). There are also efforts to create Water Catchment Area Advisory Committees (WCAAC) to 
oversee the activities of Water Resources User Associations and Water Users Associations (WUAs) formed by local communities charged with the responsibility of deciding how water is used, apportionment of water rights and decision making through the District Water Boards (WWF, 2009). The significance of institutional factors in influencing the resource management decisions of farmers is that laws, policies and programs contribute to regulatory frameworks in which farmers make their decisions (Kehrig, 2002).

\subsection{Land use policies in Kenya}

Although issues of land use policies are outside the focus of this study, an overview of land use and land policies will help in the understanding of the origins of the current natural resource problems in the MRB. Policy is formed by the existing political structures but the Kenyan political system has not been transparent and respectful on land policy developments (Kimaru and Jama, 2005). Land has often been allocated and distributed on the basis of political loyalties rather than on human and environmental needs (Hermunen, 2004). Human and environmental needs have changed a great deal while land and land use policies have remained static for about 40 years now (Hermunen, 2004).

In the absence of strict and up to date land policies, land use gets determined by three independent forces. Individual farmers who will follow their own economic needs to maintain or alter the use of land to maximize their profits, public policies get misplaced to achieve objectives not related to best land use alternatives and land use policies are affected by ad hoc decisions usually designed to alter land use patterns 
towards certain given interests (Kimaru and Jama, 2005).

Land use is based on certain given rights of ownership or right of use. These rights are determined by societal regulation, government regulation or private agreements. Land use policies consider and determine ways land resources are used and managed placing issues of ownership at a secondary level (Hermonen, 2004). These policies can be broken down into three systems of control, monitoring and administrative. Control systems consist of different plans and conservation decisions. The issue of whether control plans are realized is handled within the monitoring system while the administrative system is responsible for producing and executing the land use plans (Hermonen, 2004).

Kimaru and Jama (2005) observed that there is a difference between land policy and land use policy. Land policy is a more broad concept that focuses on ownership and laws that govern land allocation and distribution in general. Land policy can be broken into environmental, spatial and tenure dimensions. These three dimensions together with land use policies form the content of land policy. Land use policies help to balance matters of human and natural environment. The importance of satisfying people's needs, equal rights and access to land and guaranteeing everyone equal possibilities to benefit from use of land is assured in a dynamic land policy although it is yet to be effected on the ground.

The decisions made with regard to land use in the MRB have had very little to do with natural resources protection. It is a battlefield of various interest groups and sectors against limited land and water resources. According to an assessment done by ENSDA (2005) the upper basin of the Mara lost 16000 acres between 2000 and 2003 through 
forest excisions authorized by the government. In an attempt to ensure adequate protection of land use policies by communities living next to forest reserves, the Kenya government enacted a new forest law, Forest Act 2005. This law came into effect in 2007, it needs to be understood and requires community participation in forests management. This law also aims to transform forest department into an autonomous authority that will have more policing power.

Effective natural resource use policies will help to strengthen the emerging conservation initiatives to allocate environmental services equally and enhance environmental quality (Kimaru \& Jama, 2005). Since there is continuous overexploitation of water and land resources, an examination of the use of BMPs towards helping in the improvement of land and water resources is necessary. How this will be implemented is a going to be debated such that some sort of land use zoning would need to done.

\subsection{Relationship between forest conservation and water resources}

Forests store and release water to streams, rivers and ground aquifers slowly. Ground cover is the chief determinant of soil erosion. Vegetation cover holds top soils together, reduces the impact of rain droplets on the soil thus reducing erosion and runoff (Cunningham, 2003). Loose soils are more susceptible to wind and water erosion releasing soil sediments and sediment-bound pollutants to water (Cunningham, 2003). Erosion rates are low in natural forests $(0.3 \mathrm{t} / \mathrm{ha} /$ year $)$ and in the fallow phase of swidden cultivation ( $0.2 \mathrm{t} / \mathrm{ha} /$ year $)$ and in plantations where weeds and leaf litter are retained $(0.6$ $\mathrm{t} / \mathrm{ha} /$ year). Erosion rates in swidden crop fields are ten times as high as in natural forest $(2.8 \mathrm{t} / \mathrm{ha} /$ year $)$ and in plantations where weeds and litter have been removed, erosion is 
more than a hundred times as great as in natural forests (53 t/ha/year) (Nasi et al., 2002).

When natural forested landscapes are denuded, rain can compact the surface and turn soil to mud, mud clogs surface cavities in the soil, reduces infiltration of water, increases runoff, and further enhances clogging (Nasi et al., 2002) and reduces water quality.

There is evidence from other places in the world that as soon as the land cover change goes beyond $50 \%$, there is likely to be a sharp increase in runoff and peak flows (Harris, 2001). Similarly, dry season flows might be reduced by up to $75 \%$ in volume once forest lands are converted to farmlands (Richmond-Coggan, 2006). When forests are removed, the absorption capacity of the soil is reduced, resulting in a reduction in water percolating into the subsurface. In turn, groundwater recharge is lowered, leading to low dry season flows (Brooks et al., 2003).

\section{CHAPTER 3. SURVEY AND METHODOLOGY}

\subsection{Introduction}

This chapter begins with an overview of the study area, size of the land that was covered by the survey and its location. The presentation of key methodologies, some of the key questions and hypothesis that were to help in determining the most appropriate BMPs for water quality improvement that are economical and technically feasible for adoption by the farmers in the headwaters of MRB are in all in this chapter. There are also sections on data collection, data analysis and the ranking of BMPs. Determining the opportunity cost of adoption of various BMPs, estimation of the number of hectares to be placed under BMPs and the actual payment for watershed services are the final sections dealt with in this chapter. 


\subsection{Study area}

Mara River Basin is found in East Africa and is shared between Kenya and Tanzania. The Mara river itself is formed by two main rivers, the Amala and Nyangores that have their source in the MFC in Kenya. The MFC is located approximately 3000 meters above sea level. The mean annual rainfall varies between $1000 \mathrm{~mm}$ and $1600 \mathrm{~mm}$ and is distributed tri-modally with highest precipitation in April and August with some rains also in November.

The major land uses in the watershed includes gazetted indigenous and plantation forests, wildlife reserve, large-scale irrigation farming, pastoralism, commercial dairy and tea farming and with majority of the people falling under small scale farming (Mati et al., 2005). The main crops grown here are; wheat, maize, sweet potatoes, beans, pyrethrum, vegetables and bananas. The MFC is one of the five water towers in Kenya forming the headwaters of many major rivers. These rivers include the Mara, Nzoia, Yala, Nyando, Sondu, Kerio, Molo, Ewasi Ngiro, Njoro, Nderit, Makalia and Naishi. The lower section of the Mara basin is devoted to wildlife conservation, large-scale wheat farming and pastoralism.

The MFC covers an area of about 260,000 hectares $\left(900 \mathrm{Km}^{2}\right)$ and is the largest forest block in East Africa (ENSDA, 2005). The whole of MFC is broadly divided to the South and Northern Mau. The Southern forests that form the MFC are the Transmara, Ol Posimoru, Maasai Mau, Mau Narok, South West Mau, Western Mau, Mt. Londian, Eburu, Molo and South Molo. The Northern part is comprised of Tinderet, Northern Tinderet, Timboroa, Nabkoi, Kilombe hill, Metkei, Maji Mazuri, Chemorogok and Lembus forest. 

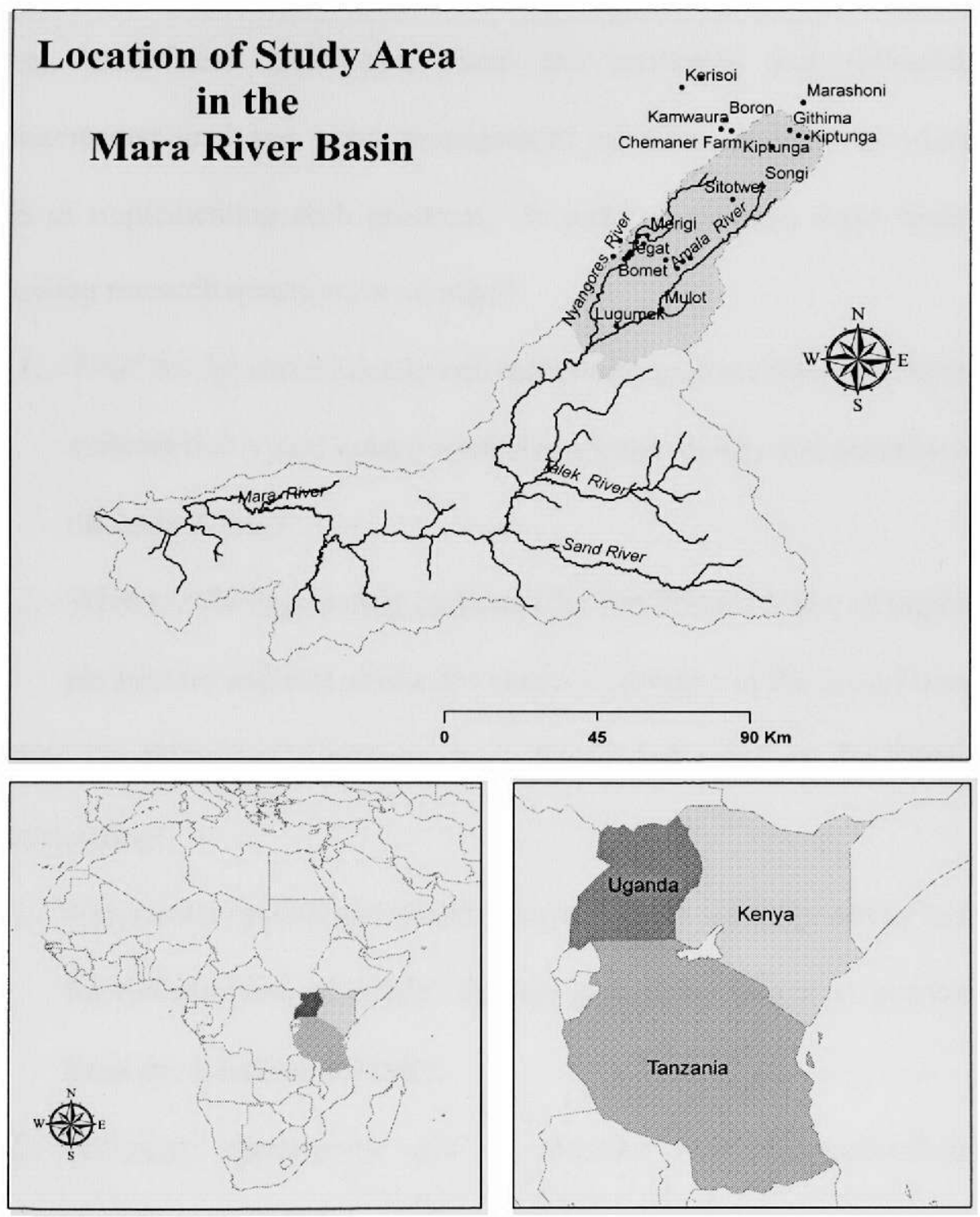

The current study concentrated on the part of the watershed that falls within the Mara River basin which includes some sections of the Maasai Mau, South West Mau and Molo. The study also covered the part of Bomet District that falls within the basin going south up to the confluence of River Nyangores and Amala. The total area covered was 245688 hectares. 


\subsection{Study questions and hypotheses}

As indicated in the first chapter, my research project had two major objectives: (a) to assess landowners' perception about the economic and technical feasibility of recommended land and water management practices, and (b) to determine farm-level costs of implementing such practices. In order to evaluate these study objectives, the following research questions were asked:

1. What are the economically and technically feasible BMPs for different farm systems that would ensure a sustained water quality and quantity improvement for the Mara River?

2. What are the opportunity costs and the Net Present Value of implementing BMPs per hectare and also across the entire headwaters of the Mara River basin?

Further, the following hypotheses were formulated based on the literature and current understanding:

1. While water quality and quantity improvement are supposed to be the main criteria for the selection of BMPs, farmers give more weight to economic criteria as a basis for selection of BMPs.

2. Economic opportunity cost of adopting best management practices is not significantly high across all the best ranked BMPs.

\subsection{Data collection}

My study was conducted using a structured interview of the farmers in the upper catchment of the MRB from Mau Forest Complex to the confluence of the Nyangores and Amala rivers. The questionnaire covered a wide range of social, economic, water 
resources, agricultural practices, forestry and natural resources management issues. Based on the literature and the outcome of the stakeholders' workshop conducted by the Global Water for Sustainability Program, particular attention was paid to the costing of Best Management Practices on lands, the perception of farmers concerning the economic feasibility and technical suitability of those practices, to different landscapes within the upper region of the basin. The study also made an assessment of how effectively these could be used towards the reduction of soil erosion problems in the watershed, water quality improvement and payment for watershed services.

Interviews were conducted at approximately $3 \mathrm{~km}$ intervals along the access roads. The roads followed were two running parallel to River Nyangores and Amala and also across the watershed at no specific intervals but where there was access by road. Small and less populated villages had only one farmer interviewed while large and more populated villages had as many as twenty people interviewed. Where there was a higher population concentration, access was also easy than where there was less concentration of people.

Farmers that were interviewed represented a wide range of age groups, and educational levels but gender was heavily skewed towards men. The interview was conducted during the summer of 2008 for 4 weeks and a total of 220 farmers were interviewed. Forty-four percent of the farmers interviewed came from Bomet district, 41 percent from Molo district, 8 percent from Nakuru district, 3 percent from Narok South and 4 percent from Narok North.

After completing the questionnaires, many farmers were very interested in the study and requested more time to understand and answer the questions. They asked me to 
return later to collect the questionnaires. Their perceptions on the quality of water in the Mara River, water resources management, population trends, land use changes, current agricultural practices and opinions on adoption of Best Management Practices were sought in my study. They were asked how they felt about the Payment for Watershed Services and how this could be made a more sustainable source of funding for implementation of practices that would ensure good quality and adequate water flows in the Mara River. At the end, 155 questionnaires were returned, which represented a $70 \%$ response rate.

Secondary data on sustainable water resources management obtained from literature of prior research in East Africa, constraints on the adoption of BMPs, opportunity costs of changing from conventional practices to agricultural best management practices, Payment for Environmental Services (PES) programs, agricultural land use changes and its effects on water, natural resources conservation and population changes was tabulated. I reviewed the literature on Payment for Watershed Services schemes and Best Management Practices already operational in other river basins in the world. The review included relevant reports and studies conducted by Hoffman (2007) and Koji (2008), World Wildlife Fund, Ewasi Ngiro South Development Authority, United Nations Environmental Program and the Food and Agricultural Organization of the United Nations in addition to published books and articles.

Complimentary interviews with protected area managers were conducted to obtain their expert opinion on the effectiveness and problems encountered with existing practices of natural resources conservation. The information gathered has formed a good basis of negotiations towards establishing realistic costs and methods that are likely to be 
more acceptable to those who will pay for implementation of BMPs and those who will implement them. The study identified the likely institutional challenges and infrastructure needs of administering the BMPs in the area. In the following sections, the key management practices and the data variables of the survey are explained.

\subsection{Perceptions and knowledge}

Farmers were first asked if they felt that there was a need to protect the watershed, if the quality of the waters in the Mara River was still good and whether they were direct beneficiaries of water from the Mara river. The question whether there were any farmers investing in the best land management practices towards the watershed protection was posed to the farmers to try to find their attitudes and awareness of the need to conserve water resources. The question on whether farmers think there has been a reduction in the quality and quantity of water in the Mara was also asked. They were then asked if they understood the meaning of best management practices.

\subsection{The description Best Management Practices}

Table 1 below provides a list and brief description of Best Management Practices that were presented for assessment by the study. Farmers were required to give their views on each in terms of water quality improvement, economic feasibility and technical suitability. Where there was some lack of understanding, farmers themselves asked questions and were able to know the practices well and how they can be applied. 


\begin{tabular}{|c|c|c|}
\hline & Best Management Practice & Brief description \\
\hline 1 & No till farming & $\begin{array}{l}\text { This requires farmers to do their farming with minimum } \\
\text { disturbance on the surface soil and vegetation cover }\end{array}$ \\
\hline 2 & Contour farming & $\begin{array}{l}\text { Developing ridges across a slope to change the direction of } \\
\text { runoff from directly flowing down the slope to around the } \\
\text { hill slope }\end{array}$ \\
\hline 3 & Contour strip cropping & $\begin{array}{l}\text { A systematic practice of growing crops alternating with } \\
\text { vegetation or grass cover. The strips are usually equal across } \\
\text { the field }\end{array}$ \\
\hline 4 & Strip cropping & $\begin{array}{l}\text { This is a practice where different crops are grown in } \\
\text { different strips across the field so that crops that hold the } \\
\text { soil together are alternated with those that do not }\end{array}$ \\
\hline 5 & Ecoagriculture & $\begin{array}{l}\text { These are land use systems that are designed to produce } \\
\text { food for communities and ecosystem services for } \\
\text { biodiversity without degrading the landscape }\end{array}$ \\
\hline 6 & Do no farming & $\begin{array}{l}\text { This is a practice where farmers are required to stop } \\
\text { completely from engaging in any form of active farming. }\end{array}$ \\
\hline 7 & $\begin{array}{l}\text { Construction of erosion } \\
\text { controls }\end{array}$ & $\begin{array}{l}\text { This is a situation where farmers in different locations use } \\
\text { the methods they are a aware of to control soil erosion }\end{array}$ \\
\hline 8 & $\begin{array}{l}\text { Streamside management } \\
\text { zones }\end{array}$ & $\begin{array}{l}\text { These are strips of land adjacent to rivers, streams or any } \\
\text { body of water that are maintained to help to protect water } \\
\text { quality and aquatic life by stopping soils from entering the } \\
\text { rivers. }\end{array}$ \\
\hline 9 & $\begin{array}{l}\text { Irrigation } \\
\text { management }\end{array}$ & $\begin{array}{l}\text { These are practices aimed at improving the efficient use of } \\
\text { water that goes to irrigated agriculture }\end{array}$ \\
\hline 10 & Mixed farming & $\begin{array}{l}\text { Growing different crops and animals in one farm thus } \\
\text { providing opportunities for recycling where wastes from one } \\
\text { type of farming can be used as inputs by another farming } \\
\text { practice. }\end{array}$ \\
\hline 11 & Crop nutrient management & $\begin{array}{l}\text { This is a practice where efficiency and reduced external } \\
\text { application of nutrient use is improved through good timing } \\
\text { and placement match of plant growth leading to reduced } \\
\text { nutrient losses. }\end{array}$ \\
\hline 12 & Conservation tillage & $\begin{array}{l}\text { This is a practice where crops are grown with minimum } \\
\text { disturbance to the soil. }\end{array}$ \\
\hline 13 & $\begin{array}{l}\text { Run-off } \\
\text { systems }\end{array}$ & $\begin{array}{l}\text { This practice helps to control excess runoff that often come } \\
\text { as a result of land use changes or land disturbances }\end{array}$ \\
\hline
\end{tabular}

All the 13 MBPs were presented to farmers and each was explained how it works.

Farmers were asked to identify those that were suitable to their farms under three criterion of water quality improvement, economic feasibility and technical suitability. The objectives of the three criterion were also explained. Using the five point Likert- 
scale, where 1 represented "I strongly disagree" and 5 "I strongly agree". The study then used the information gathered to rank the different practices based on the number of farmers who agreed that a certain practice were more or least applicable to their farms. Farmers were also asked to estimate what each BMP would cost to implement on their own farms and criteria for arriving at such costs. The reason for the need to specify the criteria was because some of the highly ranked practices for water quality may not necessarily entail low costs of implementation, rendering them economically less viable.

Practices that were seen as having soil erosion control as the basic function included contour farming, contour strip cropping, runoff management systems, streamside management zones, strip cropping and conservation tillage. The benefits of all these practices when implemented help to control erosion and improve soil fertility (Nyangena and Kohlin, 2008). The methods used in the implementation of erosion control practices included some of the practices presented as well as additional methods found from the literature.

Additional methods that farmers understood most included bench terraces, grass strips, fanya juu, cut-off drains, infiltration ditches and agroforestry. Fanya juu is a Kiswahili word for terraces that are made by digging a trench along the contour of the land throwing soil uphill to form embankments. The embankments are stabilized with fodder grasses or fast growing trees that may include fruit trees. The space between the embankments is cultivated and over time the fanya juu develops into bench terraces. In the analysis of costs of these practices, the different methods can apply across the different practices and their costs do not differ significantly. Eco-agriculture was not well understood and irrigation management practices were not being used. 


\subsection{Ranking of Best Management Practices}

According to Cunningham (2003), BMPs must meet three criteria to successfully stop natural resources degradation. First, they must be economically and socially beneficial in order for implementation to occur on any kind of broad basis. The economic situation of the farmers and their ability and willingness to implement and maintain the practices is an important aspect and also the designing of the BMP system. Also, BMPs must be easily acceptable and adoptable. Finally, practices chosen must be environmentally effective. Otherwise, even with compulsory implementation, water quality and quantity improvement will not be met. The credibility of BMP programs depend not only on compliance, but also effectiveness in meeting the set goals and objectives.

\subsection{Relationship between the three criteria}

Using the Spearman rank correlation, the three criteria of water quality improvement, economic feasibility and technical suitability were correlated to determine the strength of their relationships. The spearman coefficients range from -1.0 to +1.0 . A correlation coefficient of -1.0 indicates a perfect negative relationship, while +1.0 indicates a strong relationship. The closer the coefficient is to zero, the weaker the relationship.

A two tailed significance test was also done to determine how low or high the probability is and hence the difference between the relationships. A low probability $(\mathrm{P}<$ $0.01)$ is an indicator of statistically significant relationship while a high probability is an indicator of an insignificant relationship. 


\subsection{Opportunity cost of implementing Best Management Practices}

The PES literature identifies two bases for answering the PES question of how much the watershed service providers receive in implementing BMPs (Reis et al., 2007) (a) farm level opportunity costs of BMP adoption by upstream watershed service providers, and (b) willingness to pay of downstream service users. The first method is more popular and simpler than the second. The willingness to pay approach is more subjective and is harder to implement given the joint nature of various components of watershed services. Both PES administrators and upstream farmers who are expected to provide watershed services would find it easier to relate the costs of implementation of BMPs rather than to the complex "service outcomes" that will accrue to downstream multiple types of beneficiaries. The current study has focused on the opportunity cost of adoption.

Best Management Practices are perceived by farmers as taking on additional costs at the expense of immediate financial benefits from farming. Being able to establish an accurate opportunity cost of moving from a conventional practice to a watershed friendly practice is the first logical step to determining the amount of payment for watershed services. Most of the studies related to adoption of conservation practices have tended to use farm and farmer characteristic without taking into consideration financial incentives and how they affects farmer's decision on adoption of conservation practices (Chomba, 2004).

The cost of implementing BMPs from the farmer's perspective is a major concern. Implementing BMPs is a financial investment cost which although it may improve farm yields and incomes in the long-term, it does creates short-term uncertainty 
in the level of expected farm incomes or a reduction of the land available for farming. Farmers could incur the following types of opportunity costs when they adopt a particular land management practice:

a) New costs of making permanent change in the structure of land and other natural resources that include labor and cost of inputs

b) Increase in the annual costs of cultivation

c) Going from high value crops to low value crops

d) Reduction in crop yield

e) Complete loss of certain income-earning opportunities

Therefore, the "true" opportunity costs of making desirable land-use changes will be equal to a reduction in the net profits from farming, due to all the factors listed above. There can be exceptions to the above rule in that certain practices may result in increased crop yield and decreased costs.

\subsubsection{Opportunity costs estimation method}

The cost of farming and farm incomes before and after adoption of BMPs was estimated from the survey data. Costs and incomes were estimated as follows;

Cost of farming before BMPs adoption $=C(h)$, where $\mathrm{h}$ is the number of hectares that a farmer has put into cultivation. If the total land available for cultivation to a farmer is $h i$ hectares, when he adopts a BMP the land becomes $h j$, he loses land equivalent to $\Delta h$ because adoption of BMPs was found to take out some land from cultivation. This means therefore that;

$$
h i-h j=\Delta h
$$


The change in $\mathrm{h},(\Delta h)$ is that actual portion of the of the land taken up by MBPs. Also, expected income before adoption of BMPs was assumed to be $\pi(h)$, where $\pi$ is the income earned per hectare.

Expected income after adoption of BMPs was $\pi(h-\Delta h)$

Cost of farming after BMPs adoption was estimated to be $C(h-\Delta h)$

Incomes from farming after BMPs adoption $=\pi(h-\Delta h)$

Net income before BMPs adoption $=\pi(h)-C(h)=N I^{o}$

Net income after BMPs adoption $=\pi(h-\Delta h)-C(h-\Delta h)=N I^{I}$

Opportunity cost is the difference between incomes earned before BMPs adoption $\left(N I^{0}\right)$ and incomes after BMPs adoption $\left(N I^{l}\right)$.

Opportunity $=N I^{o}-N I^{I}$

If the outcome in equation (5) is negative, farmers gain when they implement BMPs and therefore may not require compensation unless the initial capital costs of implementation are beyond their reach. If equation (5) it is positive, they lose and therefore would require to be compensated. That is, there will be an opportunity cost of BMP adoption.

\subsubsection{Estimation of the Net Present Value opportunity cost (NPVOC) of BMPs adoption.}

Farmers were asked to give their estimates of direct annual costs of implementing selected practices as well as when using conventional land management practices. The information provided by farmers was supplemented with other costs such as area and yield losses with certain practices, in order to produce overall opportunity costs of 
various BMPs over a ten year period. The annual costs over time were discounted at $10 \%$. The $10 \%$ percent discount rate reflects the real opportunity costs of risk free investment and falls within the range where most rates are discounted in the developing countries (Pattanayak, 2004). The total costs over the ten year period were expressed in terms of total present value opportunity costs.

The study conducted a cash flow analysis to show opportunity cost borne by the farmers and established how the net present value opportunity costs (NPVOC) of costs vary over a ten year period. There were two distinct opportunity costs, the opportunity in the initial year of adoption that is very high and the subsequent opportunity costs in the subsequent years.

The present value (PV) in each year was calculated using the opportunity incurred in that year divided by the discount rate. Since the change in total land available to the farmer $h$ was $\Delta h$, and the annual incomes foregone was $\pi(h)$ per hectare, equation (5) above can be used in the estimation of Net Present Value (NPV) as follows;

$$
\mathrm{PV}=\frac{\left(N I^{0}-N I^{1}\right)}{(1+r)^{t}}
$$

The Net present Value opportunity costs is the total sum of all present values less costs of production from year 0 to year 10 . The value of $t$ in the equation 6 starts from 0 to 10 years.

$$
\mathrm{NPVOC}=\sum_{0}^{t} \frac{\left(N I_{t}^{0}-N I_{t}^{1}\right)}{(1+r)^{t}}
$$

Where, $\mathrm{t}=$ year under consideration 


\subsubsection{Key BMPs}

The study assessed 13 different BMPs and estimated the opportunity costs of implementing them. However, since some practices such as conservation tillage, contour strip cropping, strip cropping, mixed farming and runoff management systems were being regarded as methods in the implementation of other practices, an estimate of opportunity costs for 5 stand alone practices was done. Eco-agriculture and Irrigation water management practices were not familiar to the farmers living in the headwaters of the basin and therefore were not considered for adoption. Practices that were ranked highly and whose opportunity costs were estimated were erosion control systems, nutrient management practices, streamside management zones, do-no farming and no-till farming.

\subsubsection{Implementation of erosion control practices}

Erosion control practices work to reduce the impact as well as the surficial flow of water and thus increase infiltration. Implications of adopting erosion control practices are the reduction of land available for cultivation by between $5 \%$ to $42 \%$ depending on the slope and stability of soils (Tenge et al., 2005) and the method used for implementation. Unstable soils and steep slopes require closer spacing and firm methods resulting in more farmland being taken out of cultivation by BMPs and vice versa. My study has analyzed bench terraces and grass strips for erosion control measures. Adoption of bench terraces for a farm size of 3 hectares reduces land available for cultivation by between 0.5 to 1.17 hectares (Tenge et al, 2005). Establishing bench terraces leads to loss of cultivable land by between $5 \%$ to $42 \%$ while grass strips will lead to loss of between $1 \%-15 \%$ (Tenge et al., 2005). Average loss of land is therefore $24 \%$ and $8 \%$ for terraces and grass strips 
respectively. The study assumed that the average reduction of cultivable land in the bench terraces and grass strips is equivalent to reduction in incomes. My study also considered costs of adopting terraces and grass strips as these were the most popular erosion control measures with farmers. Fanya juu is very similar to bench terraces and cost differences between them are extremely small. Fanya juu is actually an immature bench terrace and therefore the study choose to analyze bench terraces.

Benefits that come directly from implementation of terraces total about KSh 315 per square meter (KSh $75=$ US\$ 1 ) and from grass strips is KSh 258 per square meter (Tenge et al, 2005), (Ekbon, 1995). It takes up to 2 years before farmers start to receive positive returns and therefore are likely to incur negative returns in the first year and about 50 percent of full earnings from the terraces and grass strips in the second year (Tenge et al, 2005).

In summary, the erosion control practices entailed the following costs and income changes:

- Reduction of land available for cultivation of traditional crops

- New income from grass or fast growing trees planted on terraces and strips

- Cost of establishing grass strips and terraces

\subsubsection{Implementation of crop nutrient management systems}

Crop nutrient management practices seek to minimize the use of external inputs and increase the reliance on internal resources from within the farm. Using internal resources enables farmers to be less dependent on chemical fertilizers that pollute water and degrade its quality. The survey data suggested that farmers are able to estimate the 
costs of adopting crop nutrient management systems based on adoption of vegetative contour strips on their farms. Using existing literature on studies done in Kenya for nutrient management practices, the study was able to estimate incomes and costs that go towards adoption of agro-forestry practices already tested for crop nutrient management. Agro-forestry was one method of soil conservation that the survey found most understood and popular to farmers. A specific method used for agro-forestry practices is alley farming where the growing of natural vegetative strips along contours on the farm is done in the form of hedgerows planted with perennial trees and fodder grass (Ekboir et al., 2002).

When trying to estimate opportunity cost in the adoption of crop nutrient practices, the study found that the amount of farmland lost due to adoption of alley farming would be about $30 \%$ per hectare. Incomes from farming were also assumed to decline by $30 \%$ per hectare in the first two years. After two years, farming costs were assumed to decline by about $15 \%$ because while there is a decline in the farmland, labour costs would reduce after the second year. Tamubula and Sinden (1999) found that the average income from conventional farming was KSh 66700 per hectare. Returns from improved farms with agro-forestry practices were KSh 60100 per hectare. This translates to about 10 percent decline in earnings. This study made the assumption that returns from farming after adoption of agro-forestry farming will reduce by about 10 percent in the third year onwards from improved farming.

In summary, the nutrient management practices entailed the following costs and income changes:

- Reduction of land available for cultivation 
- Reduction of input costs in the form of chemical fertilizers

- Additional incomes expected from planted perennial trees or fruit trees and fodder grass along contour lines

- Costs of establishing hedgegrows

\subsubsection{Implementation of Streamside Management Zones}

Streamside Management Zones are specific practices implemented in the riparian zones of rivers and streams to stop agricultural eroded soils and chemicals from reaching the rivers. Streamside Management Zones need to be of a certain width along the rivers depending on the slope of the farms. More gentle slopes require small zones and steep slopes require larger zones. However, there is no literature on the topographic conditions of all the farms that border rivers and streams in the upper section of the MRB. My study therefore took the minimum allowed width strip of 8 meters to determine the minimum costs of implementing a protection $\mathrm{SMZ}$ along the rivers and streams. According to $\mathrm{Li}$ et al. (2006), this reduces farm incomes by $3 \%$ per hectare. For those farmers who said their land borders a river, average incomes are KSh 69136 and their average costs of farming from plowing to harvest are KSh 60494.

In summary, the stream-side management practices entailed the following costs and income changes:

- Reduction of land available for farming

- Reduction in incomes as a result of reduced farmlands

- Incomes from grasses of trees planted on the streamside management zone (buffer). 
- Costs of establishing the streamside management zone when farmers may have to plant three cover of grasses

\subsubsection{Implementation of do-no-farming practices}

Given that part of the water quality and quantity reduction in the MRB has come about due to deforestation, it is expected that do no farming practices would be the most appropriate practice if it were affordable to return back as much land into forested state as possible. This practice would provide an opportunity for re-forestation of areas that were formally forested but are now under cultivation. It may not necessarily require that people move out of their land but farming communities would need to be adequately compensated for the lost farm incomes.

Once an area is re-forested, there are many benefits that are obtained from forests. In many forested areas in Kenya, it is expected that communities that live close to forests receive timber products, fruits, fuelwood, charcoal, fodder/grazing and thatch grass (Karin et al., 2008). Under this study, timber products, charcoal burning and fuelwood would not be encouraged if the Mara River watershed were to be reforested. This is because timber and fuelwood extraction have been and remain major causes of deforestation (ENSDA, 2005). Karin et al., (2008) conducted a study in Kakamega forest in Kenya and established that fodder grass, grazing and thatch grass would benefit communities up to an amount of money equivalent to US\$ 40 per hectare per year. This translates to KSh 3000 per hectare.

Based on a reforestation program in Kiambu in Kenya by Mark Nicholson of Restore the Earth Project (2001), one hectare of land would require KSh 74074 for 
reforestation. This money includes costs for tree nursery equipment, preparation and seedlings, planting equipment and labor, training and supervision. Adoption cost of do no farming in this study was also been assumed to be KSh 74074 in the Mara River Basin. Kiambu is 50 kilometers west of Nairobi and about 150 kilometers from the Mau Forest Complex. It has almost the same climatic conditions, altitude and majority of the farmers that have moved to the Mara River watershed come the community that live in Kiambu.

In summary, the do-no-farming practices entailed the following costs and income changes:

- Complete loss of farm incomes

- Reduced costs of farming

- Re-forestation costs

- Expected incomes from non-timber products

\subsubsection{Implementation of no-till farming practices}

Fowler and Rockstrom (2001) define no-till farming as a system of farming practices that helps soil management with an aim to conserve natural resources. A minimum of $30 \%$ soil surface cover by plant residues is required for conservation of soil and water with minimum soil disturbance. A study on the impact of no-till technologies in Ghana by Ekboir et al., (2002) established that no till farming would reduce farm incomes by as much as 50 percent in the first year. In the same study, farm incomes were found to have increased by $66 \%$ by the second year. In another study in Tanzania (Fowler and Rockstrom, 2001), maize yields were found to have increased by $12.7 \%$ but again cost reduction increased net income by $24 \%$. This study has assumed that gross income 
will increase by 16 percent in the second year from the conventional farming. Farming costs were estimated to reduce by $30 \%$ as a result of reduced labor and inputs as is the case in these two studies.

Adoption costs were assumed to be $25 \%$ of costs of farming under the conventional practices. These costs were based on herbicide costs, the No till farm equipments used for slashing weeds and sprayers. Farming costs were assumed to remain the same throughout while adoption costs were reduced by 50 percent as not many inputs will be required in the subsequent years.

In summary, the no-till farming practices entailed the following costs and income changes:

- Costs of establishing no-till practice

- Reduced costs of farming as a result of reduced labor requirements

- Reduced incomes in the year of adoption

- Modest increase in incomes from the second year onwards

\subsection{Sensitivity Analysis}

The determination of PWS requirement for the basin or any sub-basin is dependent upon the values of the known input factors used in the opportunity cost analysis. Final results may be different as a result of changes in the value of the known input factors that can arise out of unforeseen circumstances. To be able to take into consideration the possible changes that might occur and will affect the final results of PWS, sensitivity analysis on the starting values was conducted. The main factors that are likely to affect the adoption rate and opportunity costs of BMPs are the incomes earned 
and the costs of farming before and after implementation of BMPs. At the same time, the opportunity costs of changing from conventional to improved practices were assumed to be the basis upon which payment for watershed services will be made. One clear obstacle that limits the study from establishing the exact opportunity costs and incomes from farming after adoption of BMPs is the fact that MRB has no prior experience and no existing data. It was therefore expected that data from the survey and literature may not accurately determine the most viable PWS value. Sensitivity analysis was done to investigate how the final estimates of PWS and adoption of BMPs will change under the alternative costs and income assumptions.

The top ranked most suitable BMPs for adoption, one for each land condition were analyzed. For erosion control practices, bench terraces were analyzed, streamside management zones were analyzed for river protection, do no farming for that portion of the land occupied by farmers who are less than eight years in the basin. Do no till farming practice meets criterion of almost all land conditions.

Survey results were used as baseline data for sensitivity analysis. The resulting changes in the amount of opportunity costs were then estimated by varying incomes and costs through a margin of $25 \%$ less or above the baseline value. The baseline value was assumed to be at $100 \%$. Initially, incomes earned before and after BMPs adoption were held constant while costs were reduced by $25 \%$ from the baseline data and their net present opportunity costs estimated. Costs were again raised by $25 \%$ from the baseline data and the resulting opportunity estimated.

The second scenario is where costs were held constant and incomes were made to vary. First, incomes were reduced by $25 \%$ from the baseline results and net present value 
opportunity costs were estimated. Again, incomes were raised by 25 percent from the baseline incomes and opportunity costs and the TNPV estimated. The final estimation of PWS under the alternative costs and incomes were estimated.

\subsection{Estimation of land that need to be placed under BMPs}

Estimating the number of hectares to be placed on BMPs is the first step towards establishing the payment for watershed services scheme. The main challenge facing the MRB at this stage is not so much the water shortage but its quality and distribution. Although water quantity in most rivers that originate from the MFC has been on the decline in the last 10 years, what is being seen in the Mara river and its tributaries are large seasonal flow variations, high sedimentation and fertilizer runoff from the farms reducing the quality of water in the streams. The situation is worsening fast due to the growing demand, the unsustainable agricultural practices in the watershed and climate change effects (Mati et al., 2005). In response to these anticipated threats, implementation of BMPs to be financed through a payment for watershed service scheme is hoped will reverse or stop this trend.

Three different criteria were chosen for determining the extent of the land needed to be placed under BMPs. First, population in the Mara River basin has been steadily growing over the last 15 to 20 years and had attained a growth rate of $3.2 \%$ per year in 2005 (ENSDA, 2005). To estimate the number of hectares of land that need to be put under BMPs to maintain minimum seasonal river variations and best quality water in the river, all other things held constant, the study has taken into account population changes from the time the basin started to experience serious high seasonal river variations and 
reduced water quality. Based on population changes especially as a result of immigration, it was assumed that all the land that had recently been converted from forest to farmlands was the primary responsible factor for water problems in the basin. The land that is currently under cultivation by families who moved into the basin in the last eight years was considered an equivalent of the minimum size to be placed under BMPs. The percentage of sample farmers that fell under this category was applied to the total number of farms and the average farm size to arrive at the minimum potential size to be targeted for conservation measures.

Second, the farms that operate on steep slopes most likely experience soil erosion. The proportion of farms under cultivation in the areas that experience soil erosion should be considered for implementation of BMPs. The survey tried to find out the number of farmers whose farm experience soil erosion and this information has been extrapolated over the whole area of study. The survey excluded farmers who have been in the basin for fewer than eight years as they had been taken care of under the length of stay in the basin criteria.

Finally, the quality and vegetative cover of all the lands that border rivers and streams will also have a major influence on the river water quality (Rummer, 2004). This area was considered as a priority area for adopting suitable BMPs. The survey tried to establish the number of farmers whose land borders a river or stream. The number of farmers who said that their land bordered rivers or streams was assumed to represent the area to be placed under SMZ. The criteria also excluded those farmers who had been in the basin for less than eight years. It was established that not all the land that is settled is 
under cultivation. Only that portion of the land that is under cultivation has been considered as the area that requiring to be placed under BMPs.

\subsection{Determining Payment for Watershed Services}

Payment for Watershed Services depends on the opportunity costs of different BMPs implemented at different locations by farmers and the amount of compensation that downstream communities are willing to pay. The choice of BMPs in a particular land setting is determined by the physical and environmental conditions of the area. These include the terrain features, climate, type and status of soils (Freeman, 1999) and type of crops being grown. Hilly terrains will need different management practices from flat terrains.

The final total costs of BMPs on a farm depend on three main factors: (a) the type of BMP suitable to each land type, location and situation, subject to different technical feasibility and economic viability; (b) the area under each practice; and (c) the opportunity cost of each factor.

Since the objective of this study was to improve water quality and dry season quantity flows, the study has evaluated the opportunity costs of adopting the best ranked top 5 practices for water quality improvement, economic suitability and technical suitability. Here, the study was trying to show the actual opportunity costs of adopting specific practices under the three criteria. As indicated earlier, the minimum total number of hectares that were required to be placed under BMPs was estimated based on (a) the number of acres occupied by farmers who have been in the basin for less than eight years, (b) sample farmers who said that the proportion of their farms under 
cultivation was prone to soil erosion, and (c) the sample of farmers whose land borders rivers. The sum total of hectares under these criterion, the opportunity cost of change for each BMP, the willingness to pay by downstream communities and availability of initial funds to start off the scheme will help determine the value PWS.

\subsection{Limitations of the methodology}

It was not possible to estimate accurately the opportunity costs of adopting BMPs in the MRB, there is a lot of missing information because of lack of data for all land use types. Best Management Practices that were presented for consideration by the farmers were found lacking supportive data from the Mara Basin itself. Also, different farmers have different opportunity costs of inputs and time preferences. There was no prior experience on costs and incomes that could be used provide statistics as to how much yields are expected after a particular BMP has been implemented. A lot of assumptions on costs and incomes after adoption were made to be able to fit in the secondary information from the existing literature that may not be very accurate and relevant for the MRB situation.

When estimating costs of adopting various BMPs, farmers based their calculations on labor costs, cost of the land and some inputs that they thought would contribute towards implementation of the BMP. Farmers presented different costs under very similar conditions which otherwise would not have been so different. It is difficult to verify these costs without further research.

On the estimation of the land that needs to be placed under BMPs, information on the gradient of the land that borders rivers and streams is missing. The study has therefore 
taken the minimum recommended strip width of $8 \mathrm{~m} \mathrm{ft}$ to calculate opportunity cost. This may not give an accurate size of the land that must be placed under BMPs. Land use changes started as early as in the 1970s but since there are no data on the changes that have taken place over time, the study opted to use the land equivalent to that occupied by farmers less 8 years old in the basin. There is also no way to accurately determine the amount of land that is prone to soil erosion.

\section{CHAPTER 4. RESULTS AND DISCUSSION}

\subsection{Introduction}

The study was designed to aid in the establishment of the PWS scheme that would generate funds to be used to pay upstream farmers for costs incurred while implementing BMPs that would improve the quality and quantity of water resources. An analysis and determination of BMPs that should be implemented by farmers living upstream in the MRB was done and is discussed in this chapter. Through a ranking of various BMPs and opportunity cost calculations, the study was able to determine the most appropriate BMPs for further analysis. Using data on costs and incomes from the survey and the existing literature, opportunity costs were determined for all the technically suitable practices that would be implemented so as to reduce water resources degradation.

Findings from the survey, data analysis and interpretation of the results of the survey are presented in this chapter. The chapter begins with general findings, farmers perceptions on water resources management and best management practices. This is followed by the ranking of various BMPs where the number of farmers who preferred a particular BMP was the basis of the ranking. Opportunity costs and NPV calculation 
based on incomes and costs before and after BMPs adoption was also estimated for those practices that were highest ranked. Finally, PWS value is presented at the end of this chapter for practices that were ranked highly for water quality improvement, economic feasibility and technical suitability.

\subsection{General findings}

There was no evidence of any significant use of BMPs in the watershed during the survey. Clean cultivated fields extended everywhere across the landscape towards rivers and streams, on steep slopes that are highly erodible and towards existing forests that appeared greatly threatened by farmers who are eager to expand farmlands. The cursory observation of rivers and streams such as the Nyangores and Amala and the adjacent landscapes during my travel in the region found that they were full of suspended soil sediments and there were deep gullies on the high slopes, a clear indication of excessive soil erosion. There was recent forest clearance in some sections of the forests adjacent to settlements.

Land use changes and farming practices in recent years seem to support a much more intense and continuous cultivation. Use of fertilizers had been on the rise and was practiced by over $92 \%$ of the farmers interviewed. There had also been a dramatic increase of small scale subsistence farmers who stood at $45 \%$ and owned an average of between 0.4 and 1.2 hectares. About $24 \%$ of the farmers interviewed had been in the basin less than eight years.

Given the nature of land use practices currently being employed by farmers, it is expected that adoption of BMPs is likely to have a positive impact on the quality of water resources and landscape improvement. Through increased soil depths and water retention 
capacity, the wide gap in river flow seasonal variations will be reduced. Secondly, adoption of BMPs is expected to reduce soil erosion thus reducing both soil particles and chemical fertilizers that flow freely to streams and rivers.

\subsection{Sample characteristics}

The sampled farmers ranged in age from 18 to 76 years with a mean of 41 years. About $47 \%$ of the people interviewed have come from outside and purchased land in the MRB for settlement. About $35 \%$ were indigenous people while the remaining $18 \%$ have either leased land or are illegal settlers.

Table 2 (a) and (b) below present the length of tenure and farm size of the sample farmers. The majority of the farmers $(76 \%)$ interviewed have been practicing farming in the basin for more than eight years. Another $11.0 \%$ of the farmers had settled in the basin between five and eight years ago. Almost as many farmers $11.7 \%$ had come to the basin only in the last two and five years. A small portion of the farmer respondents $(1.3 \%)$ have been in the basin for less than 2 years.

A large proportion of farmers (43\%) owned 1 to 3 acres of land, followed by $31.5 \%$ who owned between 0.4 to 2.4 hectares of land. About $10 \%$ of the farmers owned more than 5 hectares. Further, $47 \%$ of the farmers interviewed practiced subsistence farming and owned less than 2 hectares. The other $53 \%$ were either small or large commercial farmers and all earn KSh 14800 or less per hectare per year. The main crops grown were maize, beans, potatoes, vegetables and tea.

Although about $97 \%$ of the farmers agreed that they will adopt BMPs at their own costs, farmers with small farms and earning very little income are not likely to adopt 
BMPs readily due to adoption cost constraints. Subsistence and poor farmers and those who are new to the basin may not have the incentive for, or understanding of the need for land use best management practices. The portion of subsistence farmers is rather significant, and a large number of them have stayed in the basin for more than five years.

Table 2 (a): Length of stay in the basin by farmers

\begin{tabular}{|l|r|}
\hline Characteristics & $\begin{array}{r}\text { Percent } \\
\mathrm{N}=154\end{array}$ \\
\hline Length of stay in the basin & 1.3 \\
\hline Less than 2 & 11.7 \\
\hline Between 2 -5 & 11.0 \\
\hline Between 5-8 & 76.0 \\
\hline Over 8 & \\
\hline
\end{tabular}

Table 2 (b): Distribution of farm sizes and ownership

\begin{tabular}{|l|r|}
\hline Distribution of farm size (hectares): & $\begin{array}{c}\text { Percent } \\
\mathrm{N}=146\end{array}$ \\
\hline$<0.4$ & 1.4 \\
\hline $0.4-1.2$ & 43.2 \\
\hline $1.2-2.4$ & 31.5 \\
\hline $2.4-3.6$ & 6.8 \\
\hline $3.6-5$ & 7.5 \\
\hline$>5$ & 9.6 \\
\hline Small scale commercial farmer & 53 \\
\hline Subsistence farmer & 47 \\
\hline
\end{tabular}

\subsubsection{Perceptions of farmers on status of water resources}

From the survey results, $90 \%$ of the farmers interviewed agreed that they were direct beneficiaries of water from the Mara River. At the same time, $92.8 \%$ said that the water quality in the Mara River had been deteriorating in recent years. About $78 \%$ agreed that farmers were not investing towards conservation, sustainable use and protection of 
water resources. When asked if their land was prone to soil erosion, $48 \%$ of the farmers said that their land was prone to soil erosion. At the same time, $55 \%$ of the farmers interviewed in the headwaters of the watershed have their land bordering a river or stream. Without BMPs, most soils and fertilizers from the farms find their way into the river and negatively effect water quality.

The findings from these perceptions confirm that farmers were aware that there was a need for adoption of BMPs. Farmers also understood that deforestation was a major cause of soil erosion that led to water quality problems in the basin. They were very much aware that very few of them were investing in soil and water conservation measures. Majority of the respondents did not support the idea that irrigation farming should be discouraged in the basin even though they also knew that it drew a large quantity of water from the rivers. Overall assessment was that majority of the sample farmers had a positive attitude towards adoption of BMPs and natural resources conservation.

Table 3 below gives the responses to statements by farmers on status and issues that affect water resources in the Mara based on the Likert-scale of points 1 to 5 . Point 1 represents "strongly disagree" with the statement while 5 represents "strongly agree" with the statement. More people agreed that population in the Mara River basin was growing rapidly and that deforested areas in the watershed must be reforested urgently. On a scale of 1 to 5 , people were in agreement at a mean level of 4.59 that measures should be taken to protect the MRB watershed. A mean agreement level of 4.41 was expressed with regard to the idea that that water in the Mara River had been deteriorating in recent years whereas a low mean agreement of 2.20 agreed with the statement that 
water in the Mara River was still good. Surprisingly, the mean agreement level of farmers using fartilizers was very high at 3.96 , meaning that soils are deteriorating at a very high rate.

Table 3: Perception of farmers on factors that affect water

\begin{tabular}{|l|r|r|r|}
\hline Statement & $\mathrm{N}$ & Mean & $\begin{array}{c}\text { Std. } \\
\text { Deviation }\end{array}$ \\
\hline Most farmers in the Mara river basin have migrated here from other places & 151 & 3.29 & 1.335 \\
\hline Human population in the Mara river basin is growing rapidly & 153 & 4.29 & .833 \\
\hline Areas of steep slopes should remain under forest cover and protected & 153 & 4.38 & .827 \\
\hline Deforested areas in the watershed must be reforested urgently & 154 & 4.44 & .840 \\
\hline $\begin{array}{l}\text { You are a direct beneficiary/user of the water from Mara river and/or its } \\
\text { tributaries }\end{array}$ & 153 & 4.19 & .916 \\
\hline Measures should be taken to protect the Mara River watershed & 153 & 4.59 & .807 \\
\hline $\begin{array}{l}\text { Commercial and mechanized agriculture should be restricted in the Mara } \\
\text { river basin }\end{array}$ & 153 & 3.24 & 1.391 \\
\hline Irrigation farmers should pay for water used from Mara river & 153 & 3.56 & 1.371 \\
\hline $\begin{array}{l}\text { Irrigation farming is drawing so much water and leaving very little in the } \\
\text { river to flow downstream }\end{array}$ & 152 & 3.49 & 1.282 \\
\hline Irrigation farming should not be encouraged in the Mara river basin & 153 & 2.89 & 1.374 \\
\hline Quality of water downstream the river has been deteriorating in recent years & 152 & 4.41 & .695 \\
\hline Farmers are not investing in water resources in the Mara river & 148 & 3.91 & 1.052 \\
\hline Quality of water in the Mara river is still good & 153 & 2.20 & 1.045 \\
\hline I use chemical fertilizers on my farm & 150 & 3.96 & 0.933 \\
\hline
\end{tabular}

\subsubsection{Perception on methods for implementation of BMPs}

During the interview, farmers gave their own understanding and meaning of the various practices and the methods they felt would be used in the process of implementation. The study found that some of the methods that would be used in the implementation of various BMPs were already classified as BMPs by the survey. This was confirmed from the existing literature too. When practices such as conservation tillage, contour strip cropping, strip cropping, runoff management systems and mixed farming were presented to the farmers, the response received indicated that these 
practices were methods that would serve in the implementation of other practices. Farmers were found to use conservation tillage to implement no till farming, strip cropping to implement erosion control and mixed farming and crop rotation to implement crop nutrient management. Table 4 below gives farmers views on the methods of implementing the various BMPs and the methods they understood would be used in the process of implementation.

Table 4: Farmers perception on the methods of implementing BMPs

\begin{tabular}{|c|c|}
\hline Best Management Practice & Methods for adoption \\
\hline No till farming & $\begin{array}{ll}\text { - } & \text { Agro-forestry } \\
- & \text { Fallowing } \\
- & \text { Conservation tillage }\end{array}$ \\
\hline Contour farming & $\begin{array}{l}\text { - } \text { Terraces } \\
\text { - } \quad \text { Cut strips } \\
\text { - } \quad \text { Grass strips } \\
\text { - } \quad \text { Contour strip cropping } \\
\text { - } \quad \text { Strip cropping } \\
\text { - }\end{array}$ \\
\hline Ecoagriculture & Farmers had no clear methods for adoption \\
\hline Do no farming & Re-forestation \\
\hline Construction of erosion control & $\begin{array}{ll}\text { - } & \text { Terraces } \\
\text { - } & \text { Hedgerows } \\
\text { - } & \text { Grass strips } \\
\text { - } & \text { Runoff management systems } \\
\end{array}$ \\
\hline Streamside management zones & Buffer strips along the rivers \\
\hline Irrigation water management & Farmers had no clear methods for adoption \\
\hline Crop nutrient management & $\begin{array}{l}\text { - } \text { Agro-forestry } \\
\text { - } \text { Hedgerows } \\
\text { - } \text { Terraces } \\
\text { - } \text { Grass strips } \\
\text { - } \text { Mixed farming } \\
\text { - } \text { Crop rotation }\end{array}$ \\
\hline
\end{tabular}

The above findings show that farmers in the basin do have a good understanding of some of the popular BMPs practiced in other places. Farmer's knowledge will be very 
useful as public agencies or non-governmental groups begin to work with communities to implement BMPs. Also, it is worth noting that any new BMPs that one might want to recommend for the basin may need to take into account what farmers already know to avoid any problem of in-congruence with existing practices.

\subsection{Ranking of BMPs across the three criterion}

All BMPs presented for assessment by the farmers for water quality improvement, economic feasibility and technical suitability for potential adoption were ranked based on the number of farmers who viewed them as most or least applicable on their farms. The underlying assumption was that while ranking practices based on the three criteria farmers made rational decisions that reflected both their concern for water resources protection and their perception of socioeconomic needs. Those practices that were good for water quality improvement have been ranked very high but when socioeconomic considerations were taken into account, some of them have been ranked very low. Table 5 below shows the percentage of farmers that responded positively to each BMP across the three criteria and the rank in order of popularity of each BMP. 
Table 5: Ranking of the suitability of BMPs for the three criteria

\begin{tabular}{|c|c|c|c|c|c|c|}
\hline \multirow[t]{2}{*}{ BMPs } & \multicolumn{2}{|c|}{$\begin{array}{l}\text { Water Quality } \\
\text { Improvement }\end{array}$} & \multicolumn{2}{|c|}{$\begin{array}{l}\text { Economic } \\
\text { feasibility }\end{array}$} & \multicolumn{2}{|c|}{$\begin{array}{l}\text { Technical } \\
\text { suitability }\end{array}$} \\
\hline & percent & Rank & percent & Rank & percent & Rank \\
\hline No till farming & 82.1 & 2 & 12.6 & 12 & 45.5 & 9 \\
\hline Contour farming & 73.5 & 6 & 66.7 & 2 & 67.7 & 1 \\
\hline Contour strip cropping & 70.0 & 7 & 45.0 & 9 & 57.9 & 6 \\
\hline Strip cropping & 41.7 & 13 & 45.4 & 8 & 54.7 & 8 \\
\hline Ecoagriculture & 66.9 & 8 & 41.2 & 11 & 55.9 & 7 \\
\hline Do no farming & 81.4 & 3 & 10.7 & 13 & 44.5 & 10 \\
\hline Construction of erosion control & 83.6 & 1 & 66.4 & 3 & 63.4 & 4 \\
\hline Streamside management zones & 81.0 & 4 & 51.2 & 7 & 61.4 & 5 \\
\hline Irrigation water management & 54.9 & 11 & 54.0 & 5 & 65.0 & 3 \\
\hline Mixed farming & 45.8 & 12 & 73.6 & 1 & 66.7 & 2 \\
\hline Crop nutrient management & 61.1 & 10 & 58.2 & 4 & 55.9 & 7 \\
\hline Conservation tillage & 68.8 & 9 & 42.9 & 10 & 54.4 & 9 \\
\hline Runoff management system & 76.0 & 5 & 52.8 & 6 & 67.7 & 1 \\
\hline
\end{tabular}

${ }^{1}$ percent are percentage of sample farmers that agreed that a given practice met the subject criteria. For instance, $83.6 \%$ of the farmers agreed that construction of erosion control structures will improve water quality in the rivers. The ranks are in the same order as percentages.

About $97 \%$ of the farmers agreed that they will be willing to implement BMPs. This is a good indicator of the willingness to adopt the most appropriate practices especially if farmers are compensated for doing so. If they are not compensated, they would prefer to implement the least cost practices that they can afford. On technical considerations, all these practices were given reasonably high rankings except no till and do no farming options. Some of the reasons that were given for their liking or disliking of a specific BMP included costs of adoption, convenience, if they understood how these practices worked and the fear that some practices would deprive them of their access to the use of the land. 


\subsubsection{Highest and lowest ranked BMPs across all criteria}

The highest ranked practices were also considered as most acceptable across the three criteria. Practices that received ranks above number seven with respect to all three criteria included construction of erosion control systems, runoff management systems, contour farming and streamside management zones. Those practices that were ranked lowest and therefore least acceptable from an economic point of view included do no farming, no till farming, conservation tillage and strip cropping. Although these practices received very low ratings economically, they have been analyzed further because of their high rating in the water quality improvement criteria.

\subsubsection{Ranking of BMPs for water quality improvement}

Farmers in general acknowledged that there were problems with farming practices and there was need to take action to protect water resources. On average most farmers disagreed that the quality of water in the Mara River is still good and at the same time, they strongly agreed that deforested areas in the watershed must be re-forested urgently. Figure 1 below shows how each best management practice was ranked for water quality improvement. The top five practices for consideration here include erosion control systems, no till farming, do no farming, streamside management zones and runoff management systems. 
Figure 2: Ranking of BMPs on their effectiveness on water quality improvement

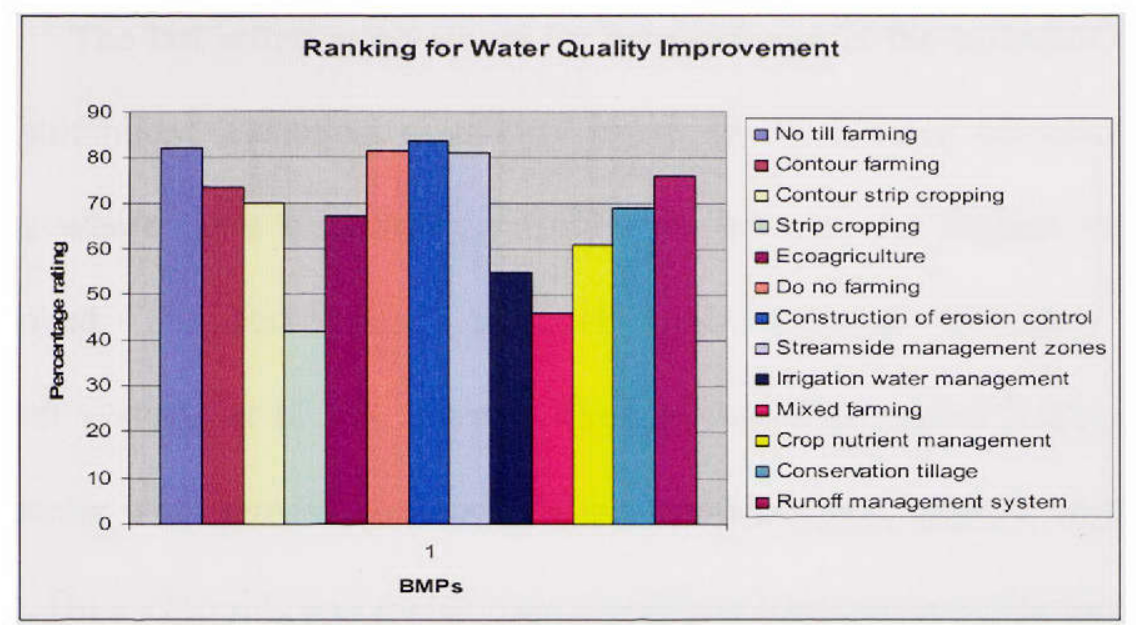

\subsubsection{Ranking of BMPs for economic feasibility}

When economic feasibility was presented to farmers as a criterion for choosing BMPs, the ranking was very different from that of water quality and quantity improvement as shown in the Figure 2 below. The top five practices here were mixed farming, contour farming, erosion control systems, crop nutrient management and contour strip cropping.

Figure 3: Ranking of BMPs on their economic feasibility

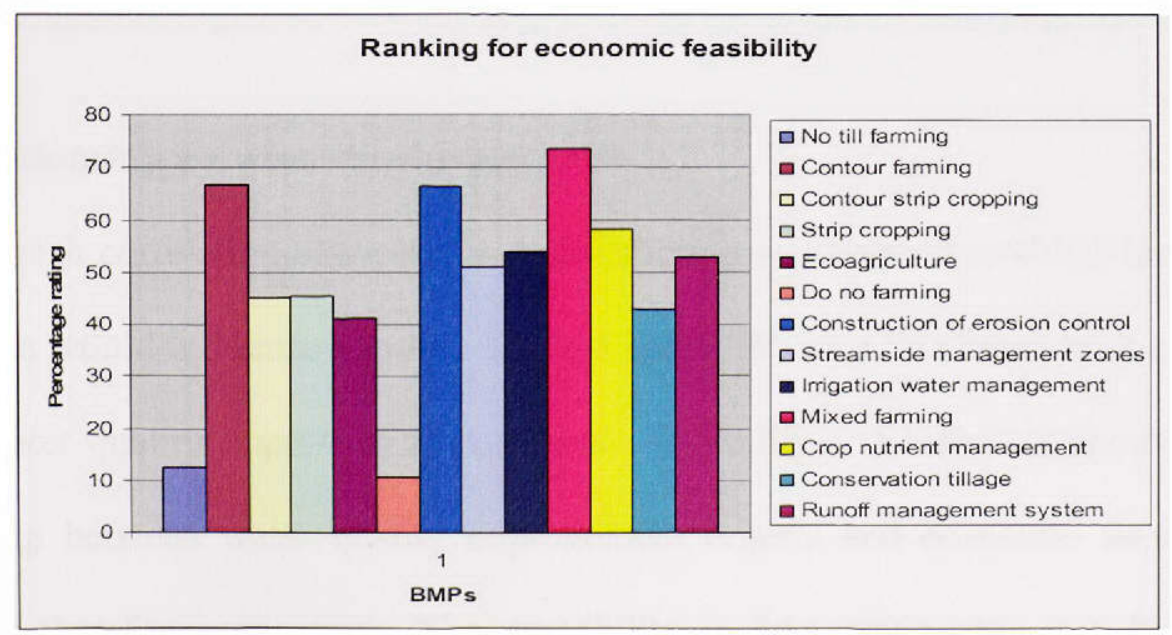




\subsubsection{Ranking of BMPs for technical suitability}

The last criterion presented for consideration in the selection of BMPs was technical suitability. Technical suitability came out with more consistent percent of agreements where there were no big differences between the highest ranked and the lowest ranked. The best ranked practices under technical suitability were runoff management systems at $67.7 \%$, contour farming at $67.7 \%$, mixed farming had $66.7 \%$, irrigation water management systems $65 \%$ and construction of erosion control structures had $63.4 \%$. Do no farming and no till were feasible to least percent of farmers.

Figure 4: Ranking of BMPs on their technical suitability

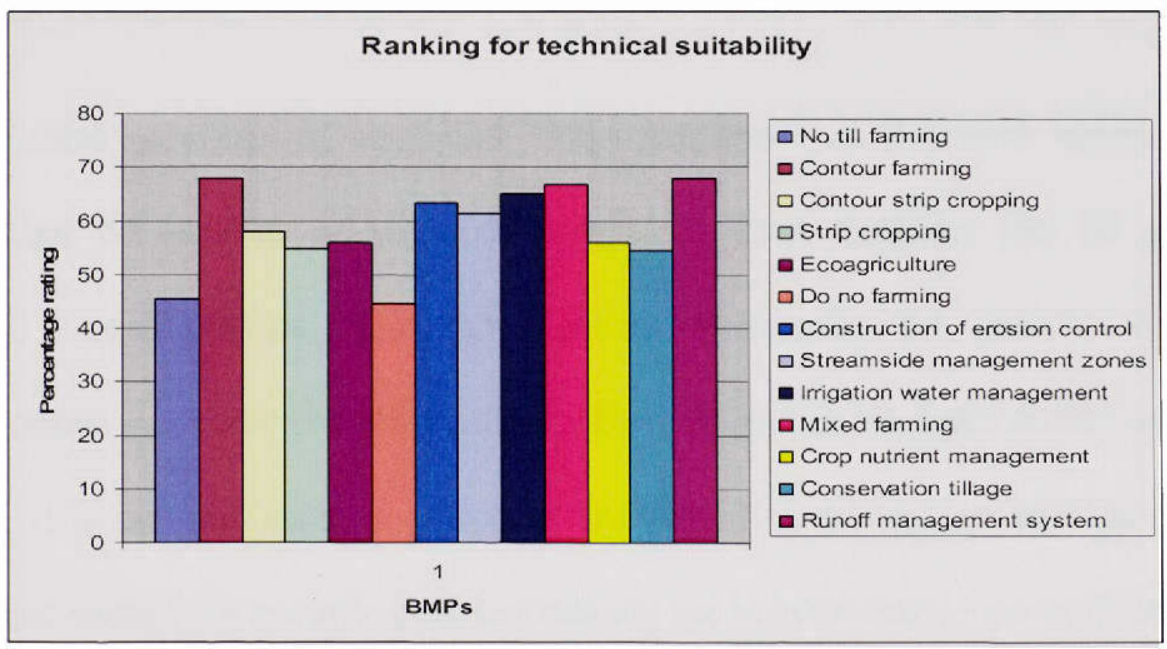

\subsubsection{Relationship between the three criteria}

A rank correlation between the three criterion was done to establish how strongly one criteria would influence another. Table 6 below shows a Spearman rank coefficients for the water quality improvement, economic feasibility and technical suitability. The relationship between water quality improvement criteria and economic feasibility is 0.264 and therefore very week. The probability in this relationship is 0.384 thus not 
statistically significant. The relationship between water quality and technical suitability of BMPs is -0.110 and therefore very weak. The probability was 0.720 and thus not statistically significant. Economic and technical suitability criteria came out with a strong relationship at 0.818 . The probability is 0.001 , it is statistically significant.

Table 6: Correlation of the three criterion

\begin{tabular}{|l|r|r|l|}
\hline Spearman's rho & $\begin{array}{l}\text { Correlation } \\
\text { coefficient }\end{array}$ & 2-tailed test & $\begin{array}{c}\text { Significance } \\
\text { (If } \mathrm{P}<0.1 \text { ) }\end{array}$ \\
\hline $\begin{array}{l}\text { Water Quality improvement } \\
\text { and Economic feasibility }\end{array}$ & 0.264 & 0.384 & Insignificant \\
\hline $\begin{array}{l}\text { Water Quality improvement } \\
\text { and Technical suitability }\end{array}$ & 0.110 & 0.720 & Insignificant \\
\hline $\begin{array}{l}\text { Economic feasibility and } \\
\text { Technical suitability }\end{array}$ & 0.818 & 0.001 & Significant \\
\hline
\end{tabular}

Further analysis of economic considerations and technical suitability criteria reveals that 67 percent of technical suitability considerations can be attributed to economic considerations. This also means that only 33 percent of economic considerations can be attributed to other factors. When people make decisions on land use changes, it is not just economic factors that would be taken into account. These other factors that contribute towards decision making are beyond that scope of this study

\subsection{Economics of implementing BMPs}

Cost of implementing various BMPs have been estimated at three levels. Farmers themselves worked out what it would cost them to implement these practices. The study has also estimated these costs based on opportunity costs of changing from conventional practices to improved practices. Based on how the farmers looked at these practices and the methods they would use to implement them, the practices have been grouped and analyzed under the following broad categories. The top three listed practices are most 
popular with farmers while the last two were least popular under economic criteria had been found to be most popular for water quality improvement.

1. Erosion control practices

2. Nutrient Management practices

3. Streamside Management Practices

4. Do no farming practices

5. No till farming practices

\subsection{Adoption of erosion control Best Management Practices}

Contour farming practice was analyzed and has been made to represent erosion control BMPS. The most popular methods under this category of practices include bench terraces, fanya juu and grass strips. Bench terraces and fanya juu methods are very similar both in implementation and investments costs. Grass strips are slightly different in costs and do not take as much land as terracing. The study has therefore estimated costs on bench terraces and grass strips under erosion control practices. Gross incomes and costs of farming under the conventional practices were computed from the survey sample data. The study found that there were fixed costs and recurring costs of adoption of each BMP.

\subsubsection{Net Present Value opportunity costs of adoption of bench terraces}

As can be seen from Table 6 (a) below, conventional gross income in year 1 immediately after adoption has been reduced by $24 \%$. This is also represents the average land size per hectare that was assumed to be taken up by terracing on every hectare of the 
affected farm. This is in line with estimates done in East Africa by Tenge et al., (2005). This income is expected to rise by $8 \%$ in year 2 due to improved soil fertility and the study assumed that this would stay constant for ten years. Average income expected from terraces per hectare was KSh 7965. This has been calculated based on the literature and assumption that a full hectare planted with grass and fodder produces $66370 \mathrm{Kgs}$ per year and each $\mathrm{Kg}$ is sold for an average $\mathrm{KSh} 0.50$ per $\mathrm{Kg}$. Since the land reduction was estimated at $24 \%$, total grass produced therefore from terraces is $0.24 \times 66370$ and total income would be KSh $0.50(0.24$ X 66370). My study assumed this to remain constant for ten years. Total income expected after adoption of terraces in KSh 65314 in year one and KSh 69900 during the period of year two to year ten. Gross income drops from KSh 75459 to Ksh 65314 in year one and rises to Ksh 69900 between the periods year two to year ten.

Adoption costs of bench terraces in year zero was the sample average cost computed from the survey data. Recurring costs from year one onwards were taken to be $10 \%$ of adoption costs. Costs reduce significantly after preparation of terraces and what remains to be done is mainly pruning and harvesting that takes very little time and labor. In the final analysis, opportunity cost was positive throughout the ten year period, meaning that farmers would actually lose money by adopting this practice. Opportunity costs were estimated at KSh 26896 during the adoption year, 12835 in year 1 and KSh 8247 between year two and ten.

The study also estimated the NPV costs of investing in bench terraces using a discount rate of 10 percent. The NPV opportunity cost was estimated to be KSh 81746 per hectare. Farmer's perception on investing in BMPs would be motivated only if the 
present value future expected net income from the BMPs exceeds the present value future expected income from using conventional practices. The future total net gains using bench terraces to control soil erosion fall below those of future net gains when using conventional practices and the practices will not easily be accepted unless there is compensation. 
Table 7 (a) Opportunity cost and Net Present Value of adoption of bench terraces

\begin{tabular}{|c|c|c|c|c|c|c|c|c|c|c|c|}
\hline Current practices & Year & Year & Year & Year & Year & Year & Year & Year & Year & Year & Year \\
\hline Variable & 0 & 1 & 2 & 3 & 4 & 5 & 6 & 7 & 8 & 9 & 10 \\
\hline \multicolumn{12}{|l|}{ Current Practice } \\
\hline Gross incomes $^{a}$ & 0 & 75459 & 75459 & 75459 & 75459 & 75459 & 75459 & 75459 & 75459 & 75459 & 75459 \\
\hline Total costs of farming $^{a}$ & 0 & 54328 & 54328 & 54328 & 54328 & 54328 & 54328 & 54328 & 54328 & 54328 & 54328 \\
\hline (A) Net Income & 0 & 21131 & 21131 & 21131 & 21131 & 21131 & 21131 & 21131 & 21131 & 21131 & 21131 \\
\hline \multicolumn{12}{|l|}{$\begin{array}{l}\text { Incomes after BMP adoption of } \\
\text { Terraces }\end{array}$} \\
\hline Gross income $^{b}$ & 0 & 57349 & 61937 & 61937 & 61937 & 61937 & 61937 & 61937 & 61937 & 61937 & 61937 \\
\hline Income from terracesc & 0 & 7965 & 7965 & 7965 & 7965 & 7965 & 7965 & 7965 & 7965 & 7965 & 7965 \\
\hline Total income & 0 & 65314 & 69902 & 69902 & 69902 & 69902 & 69902 & 69902 & 69902 & 69902 & 69902 \\
\hline Cost of farming & 0 & 54328 & 54328 & 54328 & 54328 & 54328 & 54328 & 54328 & 54328 & 54328 & 54328 \\
\hline Cost of Terracingd & 26896 & 2690 & 2690 & 2690 & 2690 & 2690 & 2690 & 2690 & 2690 & 2690 & 2690 \\
\hline Total costs - TC & 26896 & 57018 & 57018 & 57018 & 57018 & 57018 & 57018 & 57018 & 57018 & 57018 & 57018 \\
\hline (B) Net income & -26896 & 8296 & 12884 & 12884 & 12884 & 12884 & 12884 & 12884 & 12884 & 12884 & 12884 \\
\hline $\begin{array}{l}\text { (C) Annual opportunity cost of } \\
\text { adoption }[\mathrm{A}-\mathrm{B}]\end{array}$ & 26896 & 12835 & 8247 & 8247 & 8247 & 8247 & 8247 & 8247 & 8247 & 8247 & 8247 \\
\hline Present Value & 26896 & 11668 & 6816 & 6196 & 5633 & 5121 & 4655 & 4232 & 3847 & 3497 & 3180 \\
\hline TNPV & 81740 & & & & & & & & & & \\
\hline
\end{tabular}

${ }^{a}$ Sample average per hectare crop income and costs computed from the survey data

${ }^{b}$ Gross income in year 1 after adoption has been reduced by 24 percent because of lost land area

${ }^{\mathrm{c}}$ Methodology for computing income from grasses is explained in section 3.8.4

${ }^{\mathrm{d}}$ Cost of terracing in year 1 is the sample average cost computed form the survey data; maintenance cost in year 2 and onwards is considered at $10 \%$ of first year cost. 


\subsubsection{Net Present Value opportunity costs of adoption of grass strips}

Table 7 (b) show computations for the present value opportunity costs of using grass strips to control soil erosion. Grass strips use the same technique as bench terraces but are less expensive. Bench terraces use in addition to grass, fast growing trees and are slightly wider and therefore take more space. For lack of better information, the expected adoption costs for grass strips were assumed to be $40 \%$ of the costs of adoption for bench terraces. According to Tenge et al., (2005), adoption of grass strips reduces one hectare of land by $8 \%$ and each grass strip produces $23 \mathrm{~kg}$ of grass per meter square. Total grass expected from one grass striped hectare is $23 \times 10000 \times 0.08(=18400 \mathrm{~kg})$. Grass is packaged in bundles of $25 \mathrm{Kg}$ and was estimated to sell for KSh 3.0 per bundle (Tenge et al., 2005). Therefore, $18400 \mathrm{Kg}$ produced 736 bundles of grass and had a market value of KSh 2208 ( = KSh $3 \times 736$ bundles). Cost of farming was assumed to remain the same per hectare after adoption of grass strips because this does not change the labor inputs significantly. The cost of adoption of grass strip has been assumed to be $40 \%$ of the cost terracing in year zero and was reduced by $90 \%$ from year one onwards.

Initial cost of changing from conventional to implementation of grass strips was found to be KSh 25562 during the year of adoption. Because there would be not major cost and income changes in the subsequent years, opportunity cost was assumed to remain constant at KSh 6513 . The TNPV computed with a $10 \%$ rate over the period of ten years was estimated to be KSh 66581. That is, the total discounted net income from grass strip fell short of total net income from conventional practice. Therefore, unless compensated, farmers will not accept to adopt the practice. 
Table 7 (b): Opportunity costs and Net Present Value of adoption of grass strips

\begin{tabular}{|c|c|c|c|c|c|c|c|c|c|c|c|}
\hline Current practices & Year & Year & Year & Year & Year & Year & Year & Year & Year & Year & Year \\
\hline Variable & 0 & 1 & 2 & 3 & 4 & 5 & 6 & 7 & 8 & 9 & 10 \\
\hline \multicolumn{12}{|l|}{ Current Practice } \\
\hline Gross incomes ${ }^{I}$ & 0 & 75459 & 75459 & 75459 & 75459 & 75459 & 75459 & 75459 & 75459 & 75459 & 75459 \\
\hline Total costs of farming ${ }^{2}$ & 0 & 54328 & 54328 & 54328 & 54328 & 54328 & 54328 & 54328 & 54328 & 54328 & 54328 \\
\hline (A) Net Income & 0 & 21131 & 21131 & 21131 & 21131 & 21131 & 21131 & 21131 & 21131 & 21131 & 21131 \\
\hline \multicolumn{12}{|l|}{$\begin{array}{lll}\begin{array}{l}\text { Income } \\
\text { adoption }\end{array} & \text { after } & \text { BMP } \\
\end{array}$} \\
\hline Income from farming & 0 & 69422 & 69422 & 69422 & 69422 & 69422 & 69422 & 69422 & 69422 & 69422 & 69422 \\
\hline Income from grass & 0 & 2180 & 2180 & 2180 & 2180 & 2180 & 2180 & 2180 & 2180 & 2180 & 2180 \\
\hline Total income & 0 & 71602 & 71602 & 71602 & 71602 & 71602 & 71602 & 71602 & 71602 & 71602 & 71602 \\
\hline Cost of farming & 0 & 54328 & 54328 & 54328 & 54328 & 54328 & 54328 & 54328 & 54328 & 54328 & 54328 \\
\hline Cost of grass strips ${ }^{3}$ & 26562 & 2656 & 2656 & 2656 & 2656 & 2656 & 2656 & 2656 & 2656 & 2656 & 2656 \\
\hline Total costs of farming & 26562 & 56984 & 56984 & 56984 & 56984 & 56984 & 56984 & 56984 & 56984 & 56984 & 56984 \\
\hline (B)Net income & -26562 & 14618 & 14618 & 14618 & 14618 & 14618 & 14618 & 14618 & 14618 & 14618 & 14618 \\
\hline $\begin{array}{l}\text { (C) Annual opportunity cost } \\
\text { of adoption [A-B] }\end{array}$ & 26562 & 6513 & 6513 & 6513 & 6513 & 6513 & 6513 & 6513 & 6513 & 6513 & 6513 \\
\hline Present Value & 26562 & 5921 & 5383 & 4893 & 4448 & 4044 & 3676 & 3342 & 3038 & 2762 & 2511 \\
\hline TNPV & 66581 & & & & & & & & & & \\
\hline
\end{tabular}

${ }^{1}$ Gross income after adoption of grass strips reduce by $8 \%$ from the conventional practices, goes up by 12 percent in the second year and remains constant thereafter.

${ }^{2}$ Cost of farming per hectare computed from the survey.

${ }^{3}$ Cost of adoption of grass strips is $40 \%$ less that terraces and is maintained at $10 \%$ of the adoption costs from year 1 to 10 . 


\subsubsection{Net Present Value opportunity costs of adoption of crop nutrient management practices - Agro-forestry}

Table 8 below presents an analysis of the present value opportunity costs of implementation of nutrient management systems using agro-forestry system on a per hectare basis. Agro-forestry is a collective term for land use systems and technologies where woody perennial trees, shrubs, palms, bamboos and grass are grown on the same land management unit as crops (Sinclair, 1999). Adoption of agro-forestry practices reduces the cultivable land and therefore incomes by as much as $30 \%$ (Ekboir et al., 2002).

According the survey estimates, farmers were expected to incur an adoption cost of KSh 25565 during the year of implementation, also known as year zero. From year one up to ten, this cost was assumed to be $25 \%$ of the cost of adoption. The cost would be incurred on labor required for pruning, maintenance and harvesting. Results from Table 8 reveal that there were small differences in returns between conventional farming and improved farming. The present value opportunity cost in year zero was Ksh 25565 , year one and two was KSh 15598 each. From year three onwards, farmers started making net gains from the new practice amounting to KSh 1003 per hectare.

The final estimates indicate that farmers would incur a total net present value opportunity cost of KSh 48211 . This represents the amount of money that farmers would consider to be compensated if they were the ones investing in the BMPs. 
Table 8: Opportunity costs and Net Present Value of adoption of crop nutrient management practices - Agro-forestry

\begin{tabular}{|c|c|c|c|c|c|c|c|c|c|c|c|}
\hline Current practices & Year & Year & Year & Year & Year & Year & Year & Year & Year & Year & Year \\
\hline Variables & 0 & 1 & 2 & 3 & 4 & 5 & 6 & 7 & 8 & 9 & 10 \\
\hline Gross incomes & & 75459 & 75459 & 75459 & 75459 & 75459 & 75459 & 75459 & 75459 & 75459 & 75459 \\
\hline Total costs of farming & & 54328 & 54328 & 54328 & 54328 & 54328 & 54328 & 54328 & 54328 & 54328 & 54328 \\
\hline (A)Net Income & & 21131 & 21131 & 21131 & 21131 & 21131 & 21131 & 21131 & 21131 & 21131 & 21131 \\
\hline \multicolumn{12}{|l|}{ Incomes after adoption } \\
\hline Gross income $^{1}$ & 0 & 52821 & 52821 & 67913 & 67913 & 67913 & 67913 & 67913 & 67913 & 67913 & 67913 \\
\hline Income from grass and trees ${ }^{2}$ & 0 & 5282 & 5282 & 6791 & 6791 & 6791 & 6791 & 6791 & 6791 & 6791 & 6791 \\
\hline Total incomes & 0 & 58103 & 58103 & 74704 & 74704 & 74704 & 74704 & 74704 & 74704 & 74704 & 74704 \\
\hline Cost of farming ${ }^{3}$ & 0 & 46179 & 46179 & 46179 & 46179 & 46179 & 46179 & 46179 & 46179 & 46179 & 46179 \\
\hline Cost of adoption & 25565 & 6391 & 6391 & 6391 & 6391 & 6391 & 6391 & 6391 & 6391 & 6391 & 6391 \\
\hline Total costs & 25565 & 52570 & 52570 & 52570 & 52570 & 52570 & 52570 & 52570 & 52570 & 52570 & 52570 \\
\hline (B)Net income & -25565 & 5533 & 5533 & 22134 & 22134 & 22134 & 22134 & 22134 & 22134 & 22134 & 22134 \\
\hline $\begin{array}{l}\text { (C) Annual Opportunity cost } \\
{[\mathrm{A}-\mathrm{B}]}\end{array}$ & 25565 & 15598 & 15598 & -1003 & -1003 & -1003 & -1003 & -1003 & -1003 & -1003 & -1003 \\
\hline Present Value & 25565 & 14180 & 12891 & -754 & -685 & -623 & -566 & -515 & -468 & -426 & -387 \\
\hline TPV & 48211 & & & & & & & & & & \\
\hline
\end{tabular}

${ }^{1}$ Gross income after adoption of agro forestry is $30 \%$ less than income earned under conventional practices. Cost of adoption is got from the survey data.

${ }^{2}$ Income from grass sale is assumed to be $10 \%$ of the crop income, which is kind of in the same ballpark as terrance system

${ }^{3}$ Cost of farming after adoption is assumed to decline by $15 \%$. Literature supports this figure (Tamubula and Sinden, 1999) 


\subsubsection{Net Present Value opportunity costs of adoption of MZ}

The study assumed that a streamside buffer of $3 \%$ of a hectare would be taken for a SMZ. Gross income after adoption was also assumed to decline by $3 \%$ from the incomes earned under conventional farming since only eight meters on average would the land take for SMZ. Table 9 reveals that the cost of adoption of SMZ is KSh 25758 during the adoption year zero. The study further assumed that adoption costs were to go down by $90 \%$ of the of the initial adoption costs to take care of maintenance and harvesting costs. Opportunity cost was estimated at KSh 25758 in year zero and this went down to KSh 2078 in year one and remained constant all the years to ten.

The net present value was estimated to be KSh 38525 . This indicated that farmers might not undertake this investment at the expected future gains would be less than profits from the current practices. 
Table 9: Opportunity cost and Net Present Value of adoption of streamside management zones

\begin{tabular}{|c|c|c|c|c|c|c|c|c|c|c|c|}
\hline Current practices & Year & Year & Year & Year & Year & Year & Year & Year & Year & Year & Year \\
\hline Variable & 0 & 1 & 2 & 3 & 4 & 5 & 6 & 7 & 8 & 9 & 10 \\
\hline Gross incomes & 0 & 75459 & 75459 & 75459 & 75459 & 75459 & 75459 & 75459 & 75459 & 75459 & 75459 \\
\hline Costs of farming & 0 & 54328 & 54328 & 54328 & 54328 & 54328 & 54328 & 54328 & 54328 & 54328 & 54328 \\
\hline (A) Net Income & 0 & 21131 & 21131 & 21131 & 21131 & 21131 & 21131 & 21131 & 21131 & 21131 & 21131 \\
\hline \multicolumn{12}{|l|}{ Adoption of SMZ } \\
\hline Gross income $^{T}$ & 0 & 73195 & 73195 & 73195 & 73195 & 73195 & 73195 & 73195 & 73195 & 73195 & 73195 \\
\hline Income from SMZ & 0 & 1132 & 1132 & 1132 & 1132 & 1132 & 1132 & 1132 & 1132 & 1132 & 1132 \\
\hline Total income & 0 & 74327 & 74327 & 74327 & 74327 & 74327 & 74327 & 74327 & 74327 & 74327 & 74327 \\
\hline Costs of farming ${ }^{2}$ & 0 & 52698 & 52698 & 52698 & 52698 & 52698 & 52698 & 52698 & 52698 & 52698 & 52698 \\
\hline BMP adoption costs ${ }^{3}$ & 25758 & 2576 & 2576 & 2576 & 2576 & 2576 & 2576 & 2576 & 2576 & 2576 & 2576 \\
\hline total costs & 25758 & 55274 & 55274 & 55274 & 55274 & 55274 & 55274 & 55274 & 55274 & 55274 & 55274 \\
\hline (B) Net income & -25758 & 19053 & 19053 & 19053 & 19053 & 19053 & 19053 & 19053 & 19053 & 19053 & 19053 \\
\hline $\begin{array}{l}\text { (C) Opportunity cost } \\
{[\mathrm{A}-\mathrm{B}]}\end{array}$ & 25758 & 2078 & 2078 & 2078 & 2078 & 2078 & 2078 & 2078 & 2078 & 2078 & 2078 \\
\hline Present Value & 25758 & 1889 & 1717 & 1561 & 1419 & 1290 & 1173 & 1066 & 969 & 881 & 801 \\
\hline TNPV & 38525 & & & & & & & & & & \\
\hline
\end{tabular}

${ }^{1}$ Gross income is reduced by $3 \%$ because of the strip that is taken out for SMZ.

${ }^{2}$ It is assumed that costs of farming will also go down by $3 \%$ as well.

${ }^{3}$ Adoption cost is computed from the survey data, and is assumed to $10 \%$ of initial costs annually from year 1 onwards 


\subsubsection{Net Present Value opportunity costs of adoption of do no farming}

From the water quality improvement criteria, do no farming was one of the top ranked practice but again ranked lowest when economic criteria was considered. One of the biggest problems facing the headwaters section of the MRB has been deforestation. An assessment of opportunities for re-forestation as the most appropriate BMP for adoption is therefore very necessary although it may not be the most acceptable. When farmers were asked to estimate what it will cost them to adopt this practice on their farms, they did not only look at foregone farming opportunities but also the intrinsic value of the land. The average cost of adoption from the survey data was KSh 266358 per hectare per year with a standard deviation of KSh 320151 against the foregone average income of only KSh 21131 per hectare per year. The cost of adoption of do no farming practice from the survey was found to be completely out of range of any reasonable costs.

The study has therefore opted to use the cost of a re-forestation project in Kenya by Mark Nicholson of Restore the Earth Project (2001). Nicholson (2002), made an estimate in his project that to re-forest one acre of land would cost KSh 30000 . This translates to about KSh 74074 per hectare.

Using the same estimates, the study was able to estimate realistic adoption and opportunity costs for this study. Farmers would continue to benefit from non- timber products from the forests such as grazing, fodder and thatch grass. The study discourages timber, fuel wood and charcoal burning as these have been major causes of deforestation. Table 9 reveals that the costs of changing from conventional farming practices to doing no farming were much higher compared to other practices. The initial cost of adoption of do no farming and the opportunity cost is equivalent to KSh 74074 with an assumed 
annual maintenance cost of $10 \%$ of the cost of adoption for ten years. The NPV is KSh 231225. According to Holm-Mueller, (2007), Kakamega forest was estimated to provide non-timber forest benefits amounting to US\$ 40 per hectare. This study therefore assumed that the community after changing to do no farming can still receive non-timber forest products equivalent to KSh 3000 . 
Table 10: Opportunity cost and Net Present Value of adoption of do no farming

\begin{tabular}{|c|c|c|c|c|c|c|c|c|c|c|c|}
\hline & Year & Year & Year & Year & Year & Year & Year & Year & Year & Year & Year \\
\hline Current practices & 0 & 1 & 2 & 3 & 4 & 5 & 6 & 7 & 8 & 9 & 10 \\
\hline Gross income & 0 & 75459 & 75459 & 75459 & 75459 & 75459 & 75459 & 75459 & 75459 & 75459 & 75459 \\
\hline Total costs of farming & 0 & 54328 & 54328 & 54328 & 54328 & 54328 & 54328 & 54328 & 54328 & 54328 & 54328 \\
\hline (A) Net Income & 0 & 21131 & 21131 & 21131 & 21131 & 21131 & 21131 & 21131 & 21131 & 21131 & 21131 \\
\hline \multicolumn{12}{|c|}{$\begin{array}{l}\text { Incomes after adoption of } \\
\text { Do no farming }\end{array}$} \\
\hline Gross income & 0 & 3000 & 3000 & 3000 & 3000 & 3000 & 3000 & 3000 & 3000 & 3000 & 3000 \\
\hline Cost of farming & 0 & 0 & 0 & 0 & 0 & 0 & 0 & 0 & 0 & 0 & 0 \\
\hline Adoption costs ${ }^{2}$ & 74074 & 7407 & 7407 & 7407 & 7407 & 7407 & 7407 & 7407 & 7407 & 7407 & 7407 \\
\hline Total costs $-\mathrm{TC}$ & 74074 & 7407 & 7407 & 7407 & 7407 & 7407 & 7407 & 7407 & 7407 & 7407 & 7407 \\
\hline (B) Net Income & -74074 & -4407 & -4407 & -4407 & -4407 & -4407 & -4407 & -4407 & -4407 & -4407 & -4407 \\
\hline $\begin{array}{l}\text { (C) Opportunity cost } \\
\text { [A-B] }\end{array}$ & 74074 & 25538 & 25538 & 25538 & 25538 & 25538 & 25538 & 25538 & 25538 & 25538 & 25538 \\
\hline Present Value & 74074 & 23217 & 21106 & 19187 & 17443 & 15857 & 14416 & 13105 & 11914 & 10831 & 9846 \\
\hline TPV & 230996 & & & & & & & & & & \\
\hline
\end{tabular}

${ }^{1}$ Do farming will provide opportunities for re-forestation. Earnings expected from non-forestry timber products range from US\$ 5 per hectare per year in the Brazilian Amazon to as much US\$100 per hectare with majority clustered between US\$ 50- US\$ 70, but some studies done in estimate that non timber products yield US $\$ 40$ per hectare (Holm-Mueller, 2007). This study has assumed that farmers in the MRB will earn an average of US\$ $40(=\mathrm{KSh} 3000)$ per hectare per year. The study does not encourage charcoal burning and fuel wood collection from forests as these have been partly the cause of deforestation ${ }^{2}$ Adoption costs are estimated from secondary data of a reforestation project in Kenya in the central highlands that has very similar conditions as the Mara watershed. The cost of 30000 per acre ( 74074 per hectare) is comprised of cost of seedlings, tree nursery making and equipment, planting equipment and labor, training and supervision. 


\subsubsection{Net Present Value opportunity costs of adoption of no till farming}

There are two methods of not till farming, the traditional method of slashing the vegetation and the use herbicides to control the vegetation. In the traditional methods, farmers often burn the slashed vegetation and farm it for up to three years and leave it fallow for a year. When using herbicides to control vegetation, soil fertility and most characteristics are maintained and therefore farmers can farm the same land indefinitely (Ekboir et al., 2005). Farmers upstream in the MRB own small pieces of land and cannot afford to leave farms fallow at any time. Analyzing opportunity costs of indefinite use of the land was therefore the most ideal.

The study used existing literature on no till farming practices because estimates given by farmers during the survey were too costly and not realistic. The cost of adoption from the survey data was KSh 176309 per hectare with standard deviation of KSh 219946. A study done in Ghana by Ekboir et al., (2002), estimated the cost of adoption of no till farming at US\$38 (KSh 2250) per hectare. No till farming practice actually cuts down farming and input costs from conventional farming practices by about $75 \%$. Since costs of conventional farming in Kenya was estimated at KSh 54328 by farmers, no till farming costs was reduced by $40 \%$ to KSh 21731 per hectare annually by my study based on estimates of key inputs of labour, water and herbicides. Farmers were also assumed they would produce the same amount of food as before adopting no till hence there is no change in earnings.

As can be seen from Table 11 below, calculation of opportunity costs revealed that farmers would incur loses only in the first year but begin to make positive profits from year one onwards. Adoption of no till farming increased incomes by an average of 
$16 \%$ from the conventional practices. Overall, this practice recorded a net present value over the ten year period of KSh 241772 . This practice might be easier to implement compared to other practices discussed so far. 
Table 11: Opportunity cost and Net Present Value of adoption of no till farming

\begin{tabular}{|c|c|c|c|c|c|c|c|c|c|c|c|}
\hline Current Practices & Year & Year & Year & Year & Year & Year & Year & Year & Year & Year & Year \\
\hline Years & 0 & 1 & 2 & 3 & 4 & 5 & 6 & 7 & 8 & 9 & 10 \\
\hline Gross income & 0 & 75459 & 75459 & 75459 & 75459 & 75459 & 75459 & 75459 & 75459 & 75459 & 75459 \\
\hline Total costs & 0 & 54328 & 54328 & 54328 & 54328 & 54328 & 54328 & 54328 & 54328 & 54328 & 54328 \\
\hline (A) Net income & 0 & 21131 & 21131 & 21131 & 21131 & 21131 & 21131 & 21131 & 21131 & 21131 & 21131 \\
\hline $\begin{array}{l}\text { Incomes after adoption } \\
\text { of no till farming }\end{array}$ & 0 & & & & & & & & & & \\
\hline Gross income $^{1}$ & 0 & 75459 & 87532 & 87532 & 87532 & 87532 & 87532 & 87532 & 87532 & 87532 & 87532 \\
\hline Cost of farming ${ }^{2}$ & 0 & 21731 & 21731 & 21731 & 21731 & 21731 & 21731 & 21731 & 21731 & 21731 & 21731 \\
\hline cost of adoption ${ }^{3}$ & 21731 & 0 & 0 & 0 & 0 & 0 & 0 & 0 & 0 & 0 & 0 \\
\hline Total costs $-\mathrm{TC}$ & 21731 & 21731 & 21731 & 21731 & 21731 & 21731 & 21731 & 21731 & 21731 & 21731 & 21731 \\
\hline (B) Net income & -21731 & 53728 & 65801 & 65801 & 65801 & 65801 & 65801 & 65801 & 65801 & 65801 & 65801 \\
\hline $\begin{array}{l}\text { (C) Opportunity cost } \\
{[\mathrm{A}-\mathrm{B}]}\end{array}$ & 21731 & -32597 & -44670 & -44670 & -44670 & -44670 & -44670 & -44670 & -44670 & -44670 & -44670 \\
\hline Present Value & 21731 & -29633 & -36918 & -33561 & -30510 & -27737 & -25215 & -22923 & -20839 & -18945 & -17222 \\
\hline TNPV & -241772 & & & & & & & & & & \\
\hline
\end{tabular}

${ }^{1}$ It was assumed that incomes from farming remain the same before and after adoption of no till farming in the first year. In the second year, incomes go up by $16 \%$ from conventional practices.

${ }^{2}$ Cost of farming is reduced by about $40 \%$ after adoption of no till farming in terms of time, labor and inputs - experience from Ghana by Ekboir et al., (2002)

${ }^{3}$ Cost of adoption was compared with a study done in Ghana where it was found that one hectare costs US\$ 38 in buying the right tools and weed control herbicides. 


\subsection{Sensitivity analysis}

Costs and incomes were allowed to fluctuate by $25 \%$ up and down from the survey result values. The survey results were taken as the baseline values. When the costs incurred during the process of implementing bench terraces was allowed to vary reduced by $25 \%$ up and down from the baseline value without changing the value of incomes earned, the value of opportunity costs declined in the year of adoption and year one. From year two up to ten, opportunity costs were higher than the baseline value. When costs were held constant and incomes made to vary by $25 \%$ up and down from the baseline value, opportunity cost variations were not so significant. Changing costs has a greater negative influence on opportunity costs and net present value than changing the value of incomes.

Holding incomes constant and varying costs revealed insignificant changes in opportunity cost in the implementation of streamside management zones. But when incomes were allowed to vary and costs remained constant, there was an increase in opportunity costs. When incomes were increased by $25 \%$, there was a big reduction in opportunity cost to the extent that farmers would gain after adoption on SMZ.

While there was an insignificant change in no till farming, the changes in both costs and incomes brought about big differences in opportunity costs in the implementation of do no farming. Under constant incomes scenario, a reduction in costs led to a reduction in opportunity costs during the year of implementation and an increase opportunity costs in the subsequent years. An increase in costs led an increase in opportunity costs in the year of implementation and a reduction in the subsequent years. 
Total Net Present Value increased in all practices except in the implementation of do no farming. The big positive value of opportunity costs represent a more expensive BMP that would require high compensation for farmers to accept its adoption. Negative opportunity costs represent gains in incomes after adoption and therefore farmers need not be compensated.

Table 12 below shows the effect on opportunity costs and TNPV when both annual farming and adoption costs are changed while allowing incomes to remain at the baseline value as estimated from the survey data. Payment for watershed services value would be estimated based on the value of opportunity costs of change. Cost incurred during the implementation of BMPs would be a big influence on the decision to implement or to reject a BMP. The bigger the positive value of both opportunity costs TNPV, the higher the cost of PWS. 
Table 12: Sensitivity Analysis of opportunity costs when costs vary but incomes are held constant

\begin{tabular}{|c|c|c|c|c|c|c|c|c|c|c|c|c|}
\hline Practices & & \multicolumn{11}{|c|}{ Years } \\
\hline Bench terraces & $\begin{array}{l}\text { Percentage } \\
\text { Cost change }\end{array}$ & 0 & 1 & 2 & 3 & 4 & 5 & 6 & 7 & 8 & 9 & 10 \\
\hline \multirow[t]{6}{*}{ Bench terraces } & Baseline & 26896 & 12835 & 8247 & 8247 & 8247 & 8247 & 8247 & 8247 & 8247 & 8247 & 8247 \\
\hline & TNPV & 81740 & & & & & & & & & & \\
\hline & 75 & 20172 & 12162 & 12162 & 12162 & 12162 & 12162 & 12162 & 12162 & 12162 & 12162 & 12162 \\
\hline & TNPV & 94904 & & & & & & & & & & \\
\hline & 125 & 33620 & 13507 & 13507 & 13507 & 13507 & 13507 & 13507 & 13507 & 13507 & 13507 & 13507 \\
\hline & TNPV & 116616 & & & & & & & & & & \\
\hline \multirow[t]{6}{*}{ Streamside zones } & Baseline & 25758 & 2078 & 2078 & 2078 & 2078 & 2078 & 2078 & 2078 & 2078 & 2078 & 2078 \\
\hline & TNPV & 38528 & & & & & & & & & & \\
\hline & 75 & 19319 & 1841 & 1841 & 1841 & 1841 & 1841 & 1841 & 1841 & 1841 & 1841 & 1841 \\
\hline & TNPV & 30633 & & & & & & & & & & \\
\hline & 125 & 32198 & 2314 & 2314 & 2314 & 2314 & 2314 & 2314 & 2314 & 2314 & 2314 & 2314 \\
\hline & TNPV & 46418 & & & & & & & & & & \\
\hline \multirow[t]{6}{*}{ No till farming } & Baseline & 21731 & -32597 & -44670 & -44670 & -44670 & -44670 & -44670 & -44670 & -44670 & -44670 & -44670 \\
\hline & TNPV & -242773 & & & & & & & & & & \\
\hline & 75 & 16298 & -24448 & -36521 & -36521 & -36521 & -36521 & -36521 & -36521 & -36521 & -36521 & -36521 \\
\hline & TNPV & -197132 & & & & & & & & & & \\
\hline & 125 & 27164 & -40746 & -52820 & -52820 & -52819 & -52820 & -52820 & -52820 & -52819 & -52820 & -52820 \\
\hline & TNPV & -286414 & & & & & & & & & & \\
\hline \multirow[t]{6}{*}{ Do no farming } & Baseline & 74074 & 25538 & 25538 & 25538 & 25538 & 25538 & 25538 & 25538 & 25538 & 25538 & 25538 \\
\hline & TNPV & 230996 & & & & & & & & & & \\
\hline & 75 & 55,556 & 37,269 & 37,269 & 37,269 & 37,269 & 37,269 & 37,269 & 37,269 & 37,269 & 37,269 & 37,269 \\
\hline & TNPV & 284555 & & & & & & & & & & \\
\hline & 125 & 92,593 & 13,808 & 13,808 & 13,808 & 13,808 & 13,808 & 13,808 & 13,808 & 13,808 & 13,808 & 13,808 \\
\hline & TNPV & 177438 & & & & & & & & & & \\
\hline
\end{tabular}


Table 13 below shows the effects of changing incomes while costs are held at the baseline value. When incomes were reduced by $25 \%$ opportunity costs incurred when changing from conventional to improved farming reduced by a small margin under bench terraces but there was a significantly increase under SMZ. This is an indication that that income does not have a big influence on the adoption of bench terraces but would be more influential when adopting SMZ. Opportunity costs reduced under no till farming and do no farming practices revealing a positive influence in the adoption of these practices. The net present value increased slightly under bench terraces but significant in SMZ. There was a slight increase under no till farming but again a significant increase under do no farming.

When the incomes were raised by $25 \%$ from the baseline value, there was a slight increase in opportunity costs under bench terraces. There was a significant increase under SMZ, a small increase under no till farming and again a very significant increase in do no farming. Increasing incomes earned without changing costs of farming does not significantly affect adoption of bench terraces and not till farming practices. Opportunity costs of adoption of streamside management zones and do no farming practices increased when incomes were raised but costs kept at the baseline value. This reveals that costs of adoption have a much bigger influence on these practices than incomes. The NPV significantly increased across three practices, the highest being in SMZ, do no farming and bench terraces had the least increment. There was a slight decline in no till farming. 
Table 13: Sensitivity Analysis of opportunity costs when incomes vary but costs are held constant

\begin{tabular}{|c|c|c|c|c|c|c|c|c|c|c|c|c|}
\hline \multirow[t]{2}{*}{ Practices } & & \multicolumn{11}{|c|}{ Years } \\
\hline & $\begin{array}{l}\text { Percentage } \\
\text { income change }\end{array}$ & 0 & 1 & 2 & 3 & 4 & 5 & 6 & 7 & 8 & 9 & 10 \\
\hline \multirow[t]{6}{*}{ Bench terraces } & Baseline & 26896 & 12835 & 8247 & 8247 & 8247 & 8247 & 8247 & 8247 & 8247 & 8247 & 8247 \\
\hline & TNPV & 81740 & & & & & & & & & & \\
\hline & 75 & 26896 & 10298 & 6858 & 6858 & 6858 & 6858 & 6858 & 6858 & 6858 & 6858 & 6858 \\
\hline & TNPV & 72161 & & & & & & & & & & \\
\hline & 125 & 26896 & $\overline{9636}$ & 9636 & 9636 & 9636 & 9636 & 9636 & 9636 & 9636 & 9636 & 9636 \\
\hline & TNPV & 91320 & & & & & & & & & & \\
\hline \multirow[t]{6}{*}{ Streamside zones } & Baseline & 25758 & 2078 & 2078 & 2078 & 2078 & 2078 & 2078 & 2078 & 2078 & 2078 & 2078 \\
\hline & TNPV & 38525 & & & & & & & & & & \\
\hline & 75 & 25758 & 15660 & 15660 & 15660 & 15660 & 15660 & 15660 & 15660 & 15660 & 15660 & 15660 \\
\hline & TNPV & 121981 & & & & & & & & & & \\
\hline & 125 & 25758 & -11504 & -11504 & -11504 & -11504 & -11504 & -11504 & -11504 & -11504 & -11504 & -11504 \\
\hline & TNPV & -44930 & & & & & & & & & & \\
\hline \multirow[t]{6}{*}{ No till farming } & Baseline & 21731 & -32597 & -44670 & -44670 & -44670 & -44670 & -44670 & -44670 & -44670 & -44670 & -44670 \\
\hline & TNPV & 241773 & & & & & & & & & & \\
\hline & 75 & 16298 & -38030 & -47085 & -47085 & -47085 & -47085 & -47085 & -47085 & -47085 & -47085 & -47085 \\
\hline & TNPV & 264785 & & & & & & & & & & \\
\hline & 125 & 27164 & -27164 & -42256 & -42256 & -42256 & -42256 & -42256 & -42256 & -42256 & -42256 & -42256 \\
\hline & TNPV & 218761 & & & & & & & & & & \\
\hline \multirow[t]{6}{*}{ Do no farming } & Baseline & 74074 & 25538 & 25538 & 25538 & 25538 & 25538 & 25538 & 25538 & 25538 & 25538 & 25538 \\
\hline & TNPV & 230996 & & & & & & & & & & \\
\hline & 75 & 74,074 & 7,424 & 7,424 & 7,424 & 7,424 & 7,424 & 7,424 & 7,424 & 7,424 & 7,424 & 7,424 \\
\hline & TNPV & 119689 & & & & & & & & & & \\
\hline & 125 & 74,074 & 43,653 & 43,653 & 43,653 & 43,653 & 43,653 & 43,653 & 43,653 & 43,653 & 43,653 & 43,653 \\
\hline & TNPV & 342304 & & & & & & & & & & \\
\hline
\end{tabular}




\subsection{Total amount of land to be placed under BMPs}

As discussed in chapter three, the study established three criteria for determining the total number of hectares that could be placed under BMPs. First of all, water quality problems in the MRB have come about partly because of expanded agriculture, and this is as a result of human population increase. Based on population changes especially because of immigration, the assumption is that all the land that has recently been converted from forest to farmlands represents part of the equivalent of the land that is responsible for the water problems in the basin. Therefore the land that is currently under cultivation by families who moved into the basin in the last eight years is the equivalent of the number of acres that needs to be placed under BMPs. From this criterion, $24 \%$ of the farmlands that fall within the headwaters of the MRB should not be under any form of cultivation and need to be taken back to permanent vegetation.

The second criterion was the land slope factor based on some of the farmer's response that their lands were prone to soil erosion and therefore should have practices that conserve soils and stop soil erosion. It was estimated that $12 \%$ of the land on the headwaters within the MRB should either be under soil erosion control systems or taken out of cultivation and reforested. The decision on the practice to be adopted here will be determined first by the amount of money available for compensation to these farmers and the most effective practice that meets the objective of water quality improvement.

The third criterion was that farms that bordered rivers and streams should be targeted for improvement. These farms should have in place strips of vegetative lands on each side of the river that would protect the water from soils and chemicals from farms reaching the waters. The SMZs need to be at least eight meters wide between the stream 
and further into the land. From the survey, farmers that bordered rivers and were more than eight years old in the basin were $35 \%$ of the total interviewed.

According to Gereta et al. (2002), in 1973, the MFC that extends far beyond the MRB but forms the headwaters of the Mara River had a total forest cover of about $752 \mathrm{Km}^{2}$. By 1985 , this forest had been reduced to $650 \mathrm{Km}^{2}$ and again further down to $493 \mathrm{Km}^{2}$ by the year 2000. The reduction in forest cover between 1985 and 2000 was equivalent to about 15714 hectares. Water quality problems started being felt in the MRB by the late 1990 s. The minimum amount of forest cover therefore required should be close to about $650 \mathrm{Km}^{2}$, then the large seasonal flow variations and heavy sedimentation that is currently found in the streams will be reduced.

The total area surveyed was 245688 hectares. About 88964 hectares of this land need to be placed under some form of BMPs. Out of a total of $71 \%$ of the land (174438) hectares that should be targeted, $20 \%$ (35220 hectares) should not be under any form of cultivation. About 24\% (41865) hectares should have streamside management zones and finally $7 \%$ of the land (12211) hectares should have soil erosion control measures.

Table 11 below shows the percentage of farmers under different land and land cover conditions and land sizes that require to be placed under different BMPs. Following Li et al. (2006) for all those farmers that bordered rivers, the minimum allowed strip of land to be left as a buffer to protect streams and rivers should be eight meters on each side of the river. As for the farms that have highly erodible lands, the entire erodible area was assumed to be placed under permanent vegetation cover. 
Table 14: Number of hectares that need to placed under BMPs

\begin{tabular}{|c|c|c|c|c|c|}
\hline Farmer condition & Percent & $\begin{array}{l}\text { Average } \\
\text { land size } \\
\text { per farmer }\end{array}$ & $\begin{array}{l}\text { Land under } \\
\text { cultivation } \\
\text { per farmer }\end{array}$ & $\begin{array}{l}\text { Percent of } \\
\text { land to be } \\
\text { improved }\end{array}$ & $\begin{array}{l}\text { Total hectares } \\
\text { to be placed } \\
\text { under BMPs }\end{array}$ \\
\hline $\begin{array}{l}\text { Farmers who have } \\
\text { less than } 8 \text { years in } \\
\text { the basin }\end{array}$ & 24 & 11.3 & 9.4 & 20 & 34888 \\
\hline $\begin{array}{l}\text { Farmers bordering } \\
\text { a river and more } \\
\text { than } 8 \text { years in the } \\
\text { basin }\end{array}$ & 35 & 4.7 & 3.2 & 24 & 41865 \\
\hline $\begin{array}{l}\text { Farmers not } \\
\text { bordering river, } \\
\text { have soil erosion } \\
\text { and have been in } \\
\text { the basin more than } \\
8 \text { years }\end{array}$ & 12 & 5.1 & 3.1 & 7 & 12211 \\
\hline $\begin{array}{l}\text { Total land to be } \\
\text { targeted }\end{array}$ & $71=174438$ & & & 51 & 88964 \\
\hline Total land surveyed & $100=245689$ & & & & \\
\hline
\end{tabular}

\subsection{Payment for Watershed Services}

In the estimation of PWS, the study focused mainly on the portion of the land that is under cultivation. When the land under cultivation was apportioned to the farmers under the specific criterion as set out in section 4.10 , the actual land size that should be placed under BMPs changes as can be seen on Table 14 above.

Results show that the total area that required soil erosion controls was 12211 hectares. Total acreage requiring streamside management zones was 41865 and the total that required complete reforestation was 34888 hectares. Crop nutrient management and no till practices can be implemented to control soil erosion as well as on areas the require re-forestation to improve soil conservation. These specific landscape requirements were then allocated to technically suitable practices as shown in table 15 below. Opportunity 
cost for erosion control practices were calculated in Table 7 (a) and (b), Crop nutrient management was calculated in Table 8, Streamside management zones (SMZ) in Table 9, Do no farming was calculated in Table 10 and No till farming opportunity cost was calculated in Table 11.

Table 15 below shows estimates of PWS at an incremental scale where farms under different land conditions would be brought under BMPs. The assumption here is that in year zero, 5000 hectares for each of the three land conditions would be implemented with BMPs. The study does not propose that all the five practices be implemented at the same but farmers and managers of PWS can agree on the land conditions that should be implemented with which practices at a given point in time.

Opportunity costs for each of the practices in year zero was KSh 26896, for erosion controls, crop nutrient management was KSh 25565 and KSh 25758 respectively, for streamside management zones, KSh 74074 for do no farming and KSh 21731 for no till farming. These are the figures that apply when bringing new land into BMPs. The total PWS depends on the BMP itself, opportunity cost and whether it is the first time implementation.

As can be seen in Table 15 below, land that would require erosion control practices is about 12,000 hectares but has been estimated at 15000 hectares and initial total payment for watershed services would be KSh 403440000 . If all the land that borders rivers and streams were to have streamside management zones, about 40000 hectares need BMPs and a total payment for watershed services value would be KSh 1030320000. Implementation of do no farming (re-forestation) on land equivalent to that occupied by farmers who have been in the basin for less 8 years would be 35000 
hectares with a payment for watershed services value of KSh 2592590000 . Only initial year adoption costs have been estimated as these provide the actual costs required for each practice and drawing up a budget for PWS. 
Table 15: Estimation of initial year payment for watershed services using opportunity costs of the analyzed practices

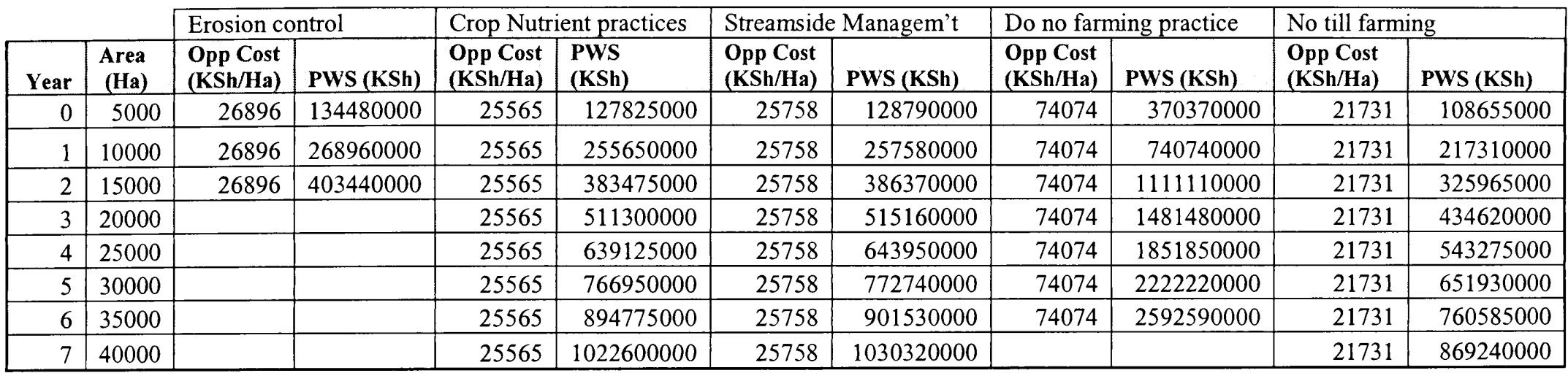

These are only estimates to show PWS values. The assumption made here is that adoption will be done incrementally taking on few hectares each time for each practice. About 5000 hectares will be placed under BMPs in year 0 under each practice, additional 5000 hectares in year 1 and another 5000 in year 2.

Any one of these practices can be adopted in place of another but those who will pay for costs of adoption need to be given an option to choose. 
Based on sensitivity analysis results, costs of adoption of BMPs have more influence on the willingness to change than changes in incomes that farmers expect to earn after adoption. A reduction or an increase in costs produced significant changes in opportunity costs of adopting BMPs than changes in incomes. Tables 16 (a) and (b) below show these variations and opportunity costs per hectare under each practice at different costs and incomes.

Table 16 (a): Opportunity costs per hectare at different costs values and constant incomes from farming

\begin{tabular}{|c|r|r|r|r|r|}
\hline Years & \multicolumn{1}{|c|}{ Cost changes } & $\begin{array}{c}\text { Bench } \\
\text { terraces }\end{array}$ & \multicolumn{1}{c|}{ SMZ } & $\begin{array}{c}\text { No till } \\
\text { Farming }\end{array}$ & $\begin{array}{c}\text { Do no } \\
\text { farming }\end{array}$ \\
\hline \multirow{2}{*}{0} & Baseline $=100 \%$ & 26896 & 25758 & 21731 & 74074 \\
\cline { 2 - 6 } & $75 \%$ & 20172 & 19319 & 16298 & 55556 \\
\cline { 2 - 6 } & $125 \%$ & 33620 & 32198 & 27164 & 92593 \\
\hline \multirow{3}{*}{1} & Baseline $=100 \%$ & 12835 & 2078 & -32597 & 25538 \\
\cline { 2 - 6 } & $75 \%$ & 12162 & 1841 & -24448 & 37269 \\
\cline { 2 - 6 } & $125 \%$ & 13507 & 2314 & -40746 & 13808 \\
\hline \multirow{2}{*}{2} & Baseline $=100 \%$ & 8247 & 2078 & -44670 & 25538 \\
\cline { 2 - 6 } & $75 \%$ & 12162 & 1814 & -36521 & 37269 \\
\cline { 2 - 6 } & $125 \%$ & 13507 & 2314 & -52820 & 13808 \\
\hline
\end{tabular}

Table 16 (b): Opportunity costs per hectare at different income levels and constant farming and adoption costs

\begin{tabular}{|c|r|r|r|r|r|}
\hline Years & Income changes & $\begin{array}{c}\text { Bench } \\
\text { terraces }\end{array}$ & \multicolumn{1}{c|}{ SMZ } & $\begin{array}{c}\text { No till } \\
\text { Farming }\end{array}$ & $\begin{array}{c}\text { Do no } \\
\text { farming }\end{array}$ \\
\hline \multirow{2}{*}{0} & Baseline $=100 \%$ & 26896 & 25758 & 21731 & 74074 \\
\cline { 2 - 6 } & $75 \%$ & 26896 & 25758 & 16298 & 74074 \\
\cline { 2 - 6 } & $125 \%$ & 26896 & 25758 & 27164 & 74074 \\
\hline \multirow{4}{*}{1} & Baseline $=100 \%$ & 12836 & 2078 & -32597 & 25538 \\
\cline { 2 - 6 } & $75 \%$ & 10298 & 15660 & -38030 & 7424 \\
\cline { 2 - 6 } & $125 \%$ & 15371 & -11504 & -27164 & 43653 \\
\hline 2 & Baseline $=100 \%$ & 8247 & 2078 & -44670 & 25538 \\
\cline { 2 - 6 } & $75 \%$ & 6858 & 15660 & -47085 & 7424 \\
\cline { 2 - 6 } & $125 \%$ & 9636 & -11504 & -42256 & 43653 \\
\hline
\end{tabular}




\section{DISCUSSION AND CONCLUSION}

This chapter has discussed the findings, interpretation and implications of various factors that would aid in effective improvement of the quality of water resources and sustainable agriculture. The required tools for successful implementation of payment for watershed services, sustainable funding sources and incremental costs for BMP adoption across the entire watershed has been discussed. The relationships between poverty and environment and how these could impact on the long-term sustainability of BMPs upstream in the Mara River Basin has also been explored.

\subsection{Introduction}

Despite the efforts by the government to stop people from encroaching the headwaters of the Mara River that also forms part of Mau Forest Complex (MFC), a casual observation estimates that about $70 \%$ of the MFC is already cleared and replaced with subsistence farming operations. This goes against the commonly held view that total exclusion through the use of both legal physical means can always work. Use of BMPs without requiring total exclusion of people can minimize water pollution and agricultural land degradation.

More than $75 \%$ of the farmers own less than 2.4 hectares and on the ground observation shows that there is mounting pressure to clear forests and use the land for cultivation. It was evidently clear that small scale farm operations are not compatible with natural resources conservation because the practices used were not environmentally sustainable, were not economical, unproductive and the farmers cannot afford to invest in land improvement BMPs. In order to develop successful watershed protection measures, 
the needs, perceptions and desires of upstream farmers should be taken into account in every step of the process.

\subsection{Payment for Watershed Services}

The overall goal of my study was to generate management-useful information necessary to implement a Payment for Watershed Services scheme, also known as the Payment for Environmental Services (PES). The PWS program would then be used to provide incentives for upstream farmers to adopt agricultural practices that do not harm water resources and also to restore the landscape where it has been degraded. Findings gave clear signals from the farmers that any potential loss of some agricultural land is a big concern but again, there was great willingness to change the land use practices to protect water resources.

\subsection{Drivers of watershed degradation}

Most of the formally forested land has been subdivided into smallest land holdings where more than 45 percent of the farmers now own between 0.1 and 1.2 hectares and $30 \%$ own between 1.2 and 2.4 hectares. Due to high population growth, cultivation has been extended to steep slopes and close to river banks, thus accelerating soil erosion and water quality degradation. A total of $55 \%$ of the farmers interviewed said that their plots bordered rivers and $48 \%$ had soil erosion on their farms. Soils were bear and susceptible to erosion throughout the headwaters on the watershed as could be seen by widespread rills and gullies on most slopes.

Human conversion of forest lands into cultivated landscapes brings with it 
fundamental changes in hydrological patterns that affect both surface and groundwater flows. These hydrological changes get more pronounced when communities are relatively poor and agricultural intensity is high. General observation during the survey indicate that agricultural expansion has been mainly in subsistence crops such as maize, potatoes and vegetables with few tea farms that belong to large corporations. Further, about $75 \%$ of the farmers upstream were found to have small farms and earn very little income from those farms. They may not have enough land to spare for BMPs adoption even if they are compensated. There are therefore high chances that they may not leave up to their commitments unless they are compensated beyond just minimum costs of adoption of BMPs.

More people are still migrating into the basin and pressure on the on upstream section of the watershed has continued to pile up. The study established that $47 \%$ of the people living in the watershed had purchased the land, $34 \%$ were the indigenous communities and the remaining $19 \%$ were either leasing farmlands, were illegal settlers or employees of various government departments who had also leased land and therefore were farmers too. These developments attest to the need for BMPS and appropriate conservation measures to protect the ecosystem in the entire MRB.

Another important driver of watershed degradation is the poverty levels of most people that live in the basin. Land is the main source of employment for communities living in the watershed. Secondly, unemployment in Kenya stands at $40 \%$ meaning that majority of graduates from schools and colleges cannot find jobs elsewhere apart from farming. About $97.4 \%$ of the farmers interviewed have completed primary school and above. Kenya's population growth rate stands at 3\% nationally (ENSDA, 2005). Majority 
of young people will be going back to farming after schooling. With this kind of trend, there is need to put in place sustainable agricultural practices in order to maintain not only agricultural outputs but also take care of the ecosystems that provide employment opportunities to the people.

\subsubsection{Role of economic incentives}

Legal protection of the watershed from encroachment has failed and there are no physical barriers that would prevent farmers from expanding their farms further aggravating the water resources problems in the Mara. Further degradation of the watershed would soon be a significant environmental and economic cost to the communities living downstream, the tourism sector, wildlife and the international community who have at one time or another made the Mara and Serengeti wildlife parks located on the downstream section of the basin their tourism destination. Economic incentives will be essential in encouraging the adoption of BMPs that would stop further watershed degradation. At the same time, given that the aim of adopting these BMPs was for water quality improvement, the BMPs that could be preferred by the farmers upstream for economic reasons may not be the most effective in water quality improvement. This further underscores the need for financial support from external sources or downstream users.

Existing natural resources management approaches in the Mara River Basin have been designed to restrict economic activities and land use with an aim of conserving forest resources. For many years now, the government has been the sole player in the protection of the upper catchment. Farming remains the only source of livelihood to the 
people upstream in the basin. With increased population growth and expanded small scale farming into forests, water degradation in the Mara River Basin has made command and control ineffective and difficult to implement. The command and control approach lacks structures that get communities involved in the management of natural resources. The only way therefore is to enlist communities in the protection of the Mara River watershed through the use of economic incentives.

There were wide variations in farmers' perceptions about the costs with respect to meeting three criteria of water quality improvement, economic feasibility and technical suitability. It was established that those practices considered most effective for water quality improvement were not necessarily the most economical as these were ranked lowest. Upstream farmers are likely to be inclined to adopt these practices unless there are sufficient incentives given to offset adoption costs. Economic incentives would ensure that as the water improvement objectives are met, the farmer's economic needs are also addressed at the same time.

The correlation of water quality improvement with economic feasibility produced an insignificant relationship. Also, a correlation of water quality improvement with technical suitability produced an insignificant relationship. Technical suitability and economic feasibility were the only attributes that had strong and significant relationship with a correlation coefficient of 0.818 . This suggests that farmers might be considering practices that are economically affordable as being also technical feasible. In other words, farmers may not favor practices that are cost prohibitive as overall feasible unless their effort is fully compensated. 


\subsubsection{Selection of BMPs for water quality improvement}

The study used several statements aimed at getting information from the farmers so as to understand their perceptions on water quality and quantity, the meaning of BMPs and their effects on water resources improvement, economic feasibility and technical suitability. It was found that economic considerations were more central in the selection of BMPs by farmers. Practices that farmers perceived to cost less to adopt were ranked very highly while those that had been ranked highly for water quality improvement but were thought to be more costly to implement were ranked lowest from an economic standpoint.

When asked what were the most effective practices for water quality improvement, more than $80 \%$ of all the respondents ranked do no farming, streamside management zones, no till farming and construction of erosion controls highest. When it came to economic considerations, except for construction of erosion controls, these practices were ranked lowest. Communities were found to be more concerned with their socio-economic needs first and thereafter than water quality improvement.

\subsubsection{How the watershed can be better protected}

What has been learned in the course of this research is that improved water resources management practices cannot be achieved if the community is simply left out of decision making so that they only get instructions, if socio-economic considerations of the people and if biophysical characteristics of the area are not considered appropriately. For the best results, adoption of BMPs should be geared towards improving all the fragile lands in the watershed through reforestation. However, this may not be realized and 
therefore the use of BMPs would be an ideal way to try and improve the environmental conditions of the watershed.

According to the Bureau of statistics guidelines, the poverty line in Kenya's rural communities based on expenditure method is KSh 14868 (US\$ 200) per year. The average farm size in the upper MRB was found to be 2.4 hectares, and $55 \%$ of the farmers earn less than KSh 12000 per hectare per year. On average therefore, about 55\% of all farmers upstream in the MRB are living below the poverty line. Payment to upstream farmers based on opportunity cost will not significantly change their lifestyles as this would leave a lot of their basic needs unmet. It is therefore important to note that great gains in achieving environmentally sustainable livelihoods can be expected through more equitable and above poverty line compensation for upstream farmers.

In summary, there were wide variations of costs with respect to meeting three criteria of water quality improvement, economic feasibility and technical suitability. It was established that those practices considered most effective for water quality improvement were not necessarily the most economical. This means that one would require a well balanced negotiation with the farmers so that as the water improvement objectives are met, farmer's economic needs are also addressed at the same time.

\subsubsection{Expected impacts of BMPs and PWS on the downstream communities}

The survey was conducted in the summer of 2008 two months after the long rains ending in the month of April. Most streams were dry and those that had water in them, had very little and was filled with soil sediments. These were signs that both the quantity and quality of water from the watershed has continued to decline. Freshwater demand by 
downstream communities has been growing rapidly with growing population, large-scale irrigation farming, expanded tourism sector and wildlife (Hoffman, 2007). The only permanent and indispensable freshwater source is the Mara River. Targeting farmers at the watershed with economic incentives to adopt land management practices that can protect water resources is likely to have a big positive impact on water available to downstream communities.

It is expected that adoption of BMPs will lead to reduced soil erosion and runoff, reduced sedimentation, reduced nutrients from farms and reforestation of the landscape. These changes would likely lead to an increase in the quality and quantity of water received by downstream communities and improve their long-term economic benefits. Improved water flow in the Mara would reduce the desire for downstream communities to start investing in alternative water sources infrastructure. The dependence of downstream communities on the Mara River demonstrates the importance of investing in the implementation of BMPs by upstream farmers. To ensure an adequate supply of clean freshwater, communities living in the basin must try to influence how land upstream is used.

\subsubsection{Opportunity costs of adoption of BMPs}

There are limited data on costs and incomes before and after adoption of BMPs in virtually all PWS schemes worldwide. This study therefore used estimates to project anticipated costs and incomes for ten years. Opportunity costs of changing from conventional practices to the use of BMPs were positive, meaning that costs were higher than expected returns for most practices for the ten year period. An analysis of costs and 
farm incomes before and after adoption of improved land management practices show that farmers will actually incur income losses as a result of cropping area being taken up by BMPs across all practices despite the expected improved yields. It was not possible to estimate accurately the earnings expected from the fourth year onwards as this was also missing in most literature. Some of the costs and incomes figures were therefore assumed to remain the same for most practices over the remaining years.

Adoption of certain BMPs by upstream farmers has great potential for contributing towards increased farm yields and incomes in addition to alleviating water resources problems. This is a finding that farmers must be made to understand as it will improve adoption potential. When setting the compensation ceiling for watershed services, the minimum value to pay should be the difference between the lost revenue and earnings from the same piece of land. The evaluation of the hypothesis in this case gives a clear and conclusive evidence that opportunity cost of adopting BMPs is highest during the year of implementation and earnings from improved practices quickly overtakes costs within three years. However, it is also understood that communities do not look at compensation from the monetary microscope alone. There are intrinsic and cultural values attached to land and these need to be considered in the development of PWS scheme.

\subsubsection{Sensitivity Analysis}

Sensitivity analysis revealed that changes in the cost of adoption of various BMPs has greater impacts on opportunity costs and PWS values than changes in incomes for bench terraces and do no farming practices. The difference between baseline values and 
the alternative cost values were higher when costs were made to vary and incomes remained constant. Farmers would be unlikely to agree to adopt BMPs on the basis that they expect higher incomes after adoption of bench terraces or do farming. Farmers would very much be concerned with the costs that go into implementing these practices than what they would earn. The general feeling therefore is that it would be easier to implement such practices if farmers are assured that adoption costs will be compensated.

As for streamside management zones and no till farming, income and cost variations produced more beneficial results for the farmers after adoption of BMPs. When incomes before and after adoption of SMZ were reduced by $25 \%$, opportunity costs rose by a very significant amount but there were insignificant opportunity cost changes due to costs and incomes variations in no till farming. Farmers could easily be persuaded to adopt these practices on the basis of expected gains in incomes.

\subsubsection{Total area to be placed under BMPs}

The rate at which population growth is rising, the rate of agricultural expansion and the diminishing forested lands in the headwaters in the MRB is evidence enough that threats to water resources are real. Rising population and agricultural expansion increases demand for more water and agricultural land. The extent to which increasing water quality and quantity can be realized therefore depends on the amount of land that would be placed under BMPs.

An assessment of the size of land that require to be placed under BMPs was done. The study estimated that all areas that experience soil erosion, those that are close to rivers and areas that have been settled less than eight years would be an ideal size of the 
land to consider placing under BMPs. This assessment was based on the findings from the survey such that in addition to specific land conditions that require improvement, water quality and quantity conditions started to decline as more people continued to move into the headwaters region of the basin estimated to be for about 10 years now. Average land ownership in the headwaters of the Mara was found to be 2.4 hectares and average area under cultivation was 1.8 hectares. Only the 1.8 hectares per farmer is being targeted for improvement.

As mentioned in section 4.10 , out of all the area surveyed, about $75 \%$ of the land is under cultivation. Out of the $75 \%, 20 \%$ is equivalent to the size of the area settled by farmers who are less than eight years in the basin. It was estimated that $24 \%$ of the land is next to rivers and streams and finally, $7 \%$ experience soil erosion. What would be required at this stage is to take and try the different practices that were found technically and economically more acceptable to different land conditions and adopt them incrementally due to high opportunity costs for some of the practices. Those areas that experience soil erosion would require erosion control practices, those that are next to rivers and streams would require streamside management zones and those that are occupied by farmers less than eight years old in the basin would need a reforestation program.

The actual land size that would need to be placed under BMPs under the different land conditions as assessed during the is as follows, streamside management zones will need 41865 hectares, equivalent of the area settled by farmers less than eight years in the basin is 34888 hectares and erosion prone areas is 12211 hectares, totaling to 88963 hectares. Investing to improve all the 88963 hectares at once is not a feasible undertaking. 
An incremental take on land of small quantities of about 5000 hectares per year in most sensitive or degraded areas would be ideal.

\subsubsection{Estimation of PWS}

Estimation of PWS is based on opportunity cost of change from conventional to improved BMPs and the size of land to be improved at a particular point in time. In addition, different land conditions and costs of most technically acceptable practices for each land condition will determine the actual PWS. As can be seen from Table 15 in chapter 4, the PWS value will rage from KSh 21731 to KSh74074 per hectare. For erodible land, minimum cost per hectare while implementing bench terraces was KSh 26896 per hectare. Estimates based in the literature of a re-forestation in Kenya costs were KSh 74074 per hectare.

It was evident that there exists large variation in per hectare PWS requirement and the need for placing large areas under BMPs. These findings show that BMP implementation in the basin is going to place huge financial burden on agencies, and in turn, downstream watershed service users. Payment for Watershed Services promoters therefore will have to exercise extreme caution in prioritizing lands for implementation and seek measures to cut down the costs of implementation. Most of the parameters on which the opportunity costs and PWS amounts are estimated in this study were based on the assumption that each farmer individually gathers the necessary inputs, including necessary labor, through an open competitive market. The costs of implementation may be reduced if certain inputs and actual physical BMP operations are done in large scales and collective manner. Further, farmers may also be encouraged to help each other out to 
keep down the overall costs of the program. The overall agreed PWS amount would depend on the negotiations between upstream and downstream communities and the specific BMPs that would be adopted.

\subsection{Institutional Mechanisms for PWS}

The Kenya government has through the Water Act, number 8 of 2002 moved to decentralize water management decision making from the central government to the local level where water is used. This has led to the establishment of the Water Resources Management Authority (WRMA), a body responsible for water management. Water Resources Management Authority now has offices at local level where communities influence decisions on how water should be managed. There are also plans to establish Water Catchment Area Advisory Committees (WCAAC) to oversee the activities of Water Resources User Associations (WRUAs) in the Mara. Mara River Water Users Associations (MRWUAs) have been formed by local communities and are charged with the responsibility of deciding how water is used, apportionment of water rights and decision making through the District Water Boards (DWB).

Although PWS can be implemented successfully in the absence of land titles or formal legal requirements, there must be strong policy and institutional support from the government and the community. There is no clear understanding of the strengths and weaknesses of the existing policy and institutional factors that would contribute towards adoption of BMPs and the development of PWS. Strengthening the MRWUA would be primary factor towards building a structure that links both downstream and upstream communities. In addition, there is need to also build Mara River Watershed Advisory 
Committee (MRWAC) that would bring together all upstream communities to agree on specified agendas that are in the interest of all the people living in the basin. This is a process that would require funding as these institutions are at their infancy, do not have money and lack structures and personnel. Establishing an institutional mechanism that brings on board all farmers to get involved and build tangible organizations and rules to promote PWS objectives with clear internal rules of arrangement and well negotiated settlements to rule out fraud or non-compliance that would need to be undertaken before a PWS program is implemented.

\subsection{Financing PWS}

The current study advocates strongly for compensation to upstream farmers for adoption of BMPs from funds given by downstream communities. However, this being a new initiative that has not been practiced before, there are no structures for implementation, there are no trained personnel and there is likely to be some resistance from the local people as a result of lack adequate trust. It would be ideal for start up funds to be provided by either International Non-Governmental Organizations or the Government. Once the start up funds run out, downstream communities would have been prepared, structures created and trust build for them to take over and pay for the watershed services.

As can be seen from Figure 5 below, $42 \%$ of the farmers were of the opinion that international Non-Governmental Organizations (NGOs) were the most sustainable source of funding towards implementation of PWS. The study finds this a justified perception that applies to the starting of the PWS program as they do not have a link as yet to the 
downstream communities. They cannot trust the government because the only experience they have so far with it is the use of command and control regulations. About $30 \%$ felt that government funding was the most sustainable source. This is also true because besides International Organizations, the only other institution that has been known to finance public or social projects is the government. However, less developed country governments get funds for development projects from external donors. There is no experience where these people have seen downstream communities financing upstream farmers to adopt BMPs.

About $14 \%$ said it was downstream communities and about $12 \%$ said self financing was the most sustainable option. Those that said that PWS should be financed by downstream communities felt that since it was to the benefit of downstream communities to adopt BMPs, they should finance the costs of adoption. About $12 \%$ said that it was their moral responsibility to protect the environment and therefore did not need to be compensated for doing so. This is just a good indicator that there are people in the MRB that are willing to sacrifice their economic benefits to protect the environment but will be the least successful avenue to follow in the implementation of PWS.

Figure 5: Farmer's view on the most sustainable source of funding for PWS

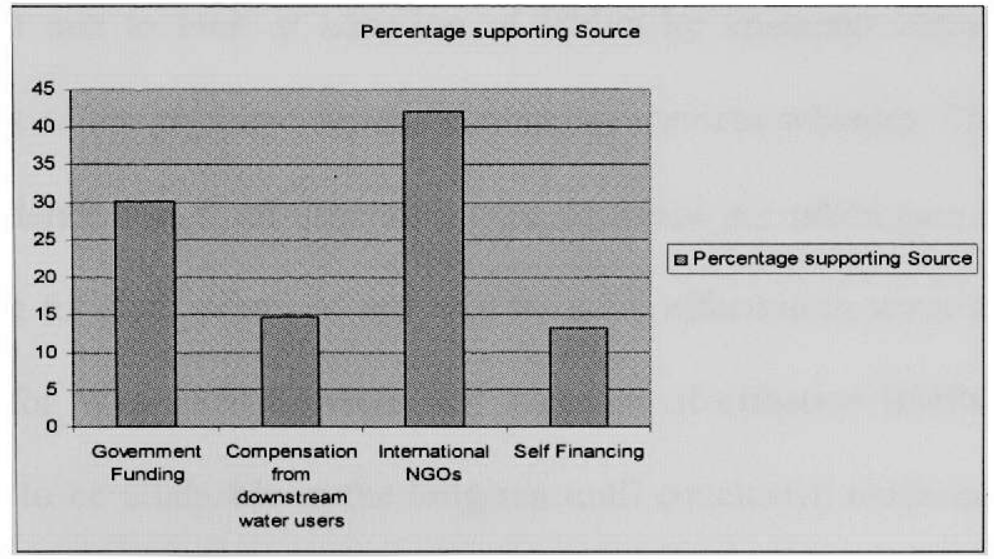


The reality in the world over is that international NGOs often face high fluctuations in their financial ability that is also given over a limited period of time. It is therefore not the most sustainable source of funding but could be used in starting the scheme or together with another source to close gaps when there are shortages. Most governments in less developed countries (LDCs) are not well endowed with resources to be able to finance environmental conservation. Self financing will not raise the necessary funds to meet water quality improvement objectives desired. From previous studies done in the downstream section of the basin, communities there have the resources to meet the payment for watershed services costs. Further research in sustainable source of funding towards PWS is however needed for all the individual sectors downstream that benefit from the Mara River. This will establish both the capacity and their level of consumption so that each will be made to pay appropriately

\subsection{Conclusion}

There are clear gaps between the needs of the environment and those of the farmers. However, farmers need to be made to understand that adoption of BMPs is a long-term strategy that will benefit them directly as well as the environment. This study is the first one to look at adoption of BMPs by upstream communities as a critical component of the payment for environmental services schemes. The overall assessment found evidence that if all economic considerations are taken care of, farmers upstream will accept to adopt practices that will be more effective in water quality improvement. Payment for Watershed Services and adoption of effective BMPs should therefore be presumed to be attainable in the long-run until conclusive evidence suggests otherwise. 
This is because through well negotiated agreements and collaboration, upstream farmers will be willing to receive compensation and in turn to implement BMPs as required.

After making adjustments between the average farms that farmers own and the actual land under cultivation, it was also established that about $51.3 \%$ of the land that is currently under cultivation must be placed under some form of BMPs while at least $20 \%$ of the $51.3 \%$ should be completely reforested. It is therefore important to plan for the best case scenario for water quality improvement whereby the highest ranked BMPs for water quality improvement would need to be considered alongside those that were identified as most economical and therefore most acceptable.

The final costs of implementing BMPs in addition to opportunity costs considerations would need a negotiation process to establish the total socio-economic needs for the farmers. This is due to high levels of poverty among the subsistence farmers upstream. This will guarantee firm commitments and have the most effective BMPs adopted thus providing a fair playing ground where downstream communities have an opportunity to determine the best level of commitment and quality of watershed services produced while at the same time upstream communities get adequate incentives towards conservation.

The MRB occupies a small section of the Mau Forest Complex. Continued poor agricultural practices by communities in the rest of the MFC will certainly affect the success of BMPs adoption in the MRB portion of the watershed. The level of poverty among the farmers is also going to be a major determining factor in the level of success of PWS and BMPs adoption. Another factor will be the continued migration of people into the basin that will continue to change the dynamics of BMPs implementation and 
PWS. The use of government command and control regulations must be strengthened for economic incentive policies to succeed.

Finally, three pilot PWS schemes under the three criterion of length of stay, areas prone to soil erosion and farms that border rivers should be initiated before a full scale PWS scheme across the upper watershed is implemented. Total land size for each pilot scheme and targeted lands should be decided by all stakeholders. In this pilot scheme, specific BMPs need to be identified and used to provide a training ground for the rest of areas.

\subsubsection{Recommendations}

i. Although majority of farmers living in the headwaters of the MRB are mainly subsistence and have not yet adopted BMPs, they recognize that adoption has environmental benefits for downstream communities. Changing from unsustainable agricultural practices is likely to succeed through the use of economic incentives to promote the use of BMPs by all farmers living in the headwaters of the Mara river.

ii In the headwaters of the Mara River Basin, the risk of intensive agricultural practices contribute greatly towards water quality reduction in the Mara river. Adjustments to the use of highest ranked water quality improvement BMPs therefore should be used as a basis for determining PWS and economic criteria should only be considered if there are problems with willingness and ability to pay by the downstream communities.

iii As population growth and agricultural impacts in the headwaters of the Mara river are pushing the watershed towards water scarcity, a voluntary strategy where farmers 
are asked and agree to get involved in the protection and improvement of water resources is likely succeed where command and control strategy has failed. This however would require some education through workshops to make farmers understand the benefits of BMPs adoption and how PWS works. Educating the farmers, government, downstream business community and all other stakeholders would be the ideal starting point of a PWS scheme.

iv Although there has been significant steps from the government to decentralize water resources management, the emerging institutional structures still lack collaborative and trans-boundary strategies of sharing water resources between Kenya and Tanzania. A need for strong partnerships from the headwaters, middle basin, the wildlife authority, mining, fisheries and all other stakeholders is the only strategy that can create a structure where PWS can be implemented. There is need for more research on institutional strengths and weaknesses in the management of funds and community mobilization. There is also a need for a platform where each specific stakeholder can be able articulate their views, needs and the way forward.

$\mathrm{v}$ As there is currently no PWS experience in the MRB, implementation of PWS scheme would require institutions that would easily gain trust from all the communities. It was established during the survey that international organizations are most trusted institutions that should carry on the task of initial implementation of PWS for purposes of funding and building PWS structures. Adoption of BMPs on all the land that requires improvement should be incremental and in phases because initial opportunity costs are very high.

vi As the area that require to be placed under some kind of BMPs is large, the costs of 
implementation are going to be quite significant. As a cost cutting measure, public agencies may encourage farmers to develop their own associations or organizations to establish large-scale, common resource pools for supply conservation inputs such as seedlings, plants, equipment, chemicals and even voluntary labor. The agencies must be involved in providing necessary technical advice through such communitybased organizations. 


\section{REFERENCES}

Anthon Earle, Jaqui Goldin and Phemo Kgomotso, 2005. Domestic Water provision in the Democratic of South Africa - challenges and changes, University of Pretoria.

Antle J. M. and Valdivia R.O. 2005. Modeling the supply of environmental services from Agriculture. Department of Agricultural Economics and Economics, Montana Sate University. Httt/www.tradeoffs.montana.edu/pdf/mdapproach.pdf

Azene, Bekele-Tesemma and Gathiru Kimaru. 2006. Participatory watershed management: Lessons from RELMA's work with farmers in eastern Africa. ICRAF Working Paper no 22. Published by the World Agroforestry Centre United Nations Avenue PO Box 30677, GPO 00100, Nairobi, Kenya

Brooks K. N., Floliott P. F., Gregersen H. M. DeBano L. F. 2003. Hydrology and management of watsheds. Iowa State Press, A Blackwell publishing company. 2121 State avenue, Ames, Iowa 50014. ISBN 0-8138-2985-2

Bollinger A., Hansen K.D., Fowler R., 2005. Constraints limiting smallholder adoption of conservation Agriculture: Some observations based on three South African smallholderoriented programmes. ARC Grain crops institute, Postbag X 9059, Pietermaritzburg 3201, South Africa.

Brroks K.N, Ffolliott P.F, Hans M. Gregersen, Leonard F. DeBano: Hydrology and the Management of Watersheds, Third Edition. ISBN - 9780813829852. Iowa State Press, Ablackwell Publishing Company.

Buck L. E., Milder J. C., Gavin T. A, and Mukherjee I., 2006. Understanding Ecoagriculture: A framework for measuring landscape performance. Department of natural resources. Cornell University, Ithaca, NY.

Chikozho C. 2005. Policy and Institutional dimensions of integrated river basin management, broadening stakeholder participatory processes in the Inkomati River basin on South Africa and the Panagni River basin of Tanzania, No. 12. Centre for applied social sciences and programme for land and Agrarian studies, South Africa.

Clay, D. C., V. Kelly, E. Mpyisi and T. Reardon 2002. Input Use and Soil Conservation Investments among Farm Households in Rwanda: Patterns and Determinants. Natural Resources Management in African Agriculture, New York, NY, CABI International.

Clint Hilliard, Nancy Scott, Armando Lessa, Sharon Reedyk, 2002. Agricultural best management practices for the Canadian Prairies. Sponsored by Canada-Saskatchewan Agri-Food Innovation Fund, File No. 6672-1-12-1-18 
Cohen M.J., Brown M.T., and Shepherd K.D, 2006. Estimating the environmental costs of soil erosion at multiple scales in Kenya using emergy sunthesis. Agriculture Ecosystems and Environment 114 (2006) 249-269. Available online at www.sciencedirect.com.

Dillaha T, Ferraro P, Huang M, Southgate D, Upadhyaya S. and Wunder S. 2007. Payment for Environmental Services, Regional Sytheses, USAID PES brief 7.

Drechsel P., Olaleye A., Adeoti A., Thiombiano L., and Vohland, K., 2005. Adoption driver and constraints of resource conservation technologies in sub-Saharan Africa. FAO Regional Office for Africa, Accra, Ghana.

Ekboir J., Boa K., and Daankyi A.A, 2002. Impact of No-Till Technologies in Ghana. Mexico. Economics Program Paper 02-01, ISSN: 1405-7735.

Freeman Peter H, 1999. Mapping the Range of Proven Soil Management Practices in Africa Using Digital Maps and Case Studies by. Development Ecology Information Service. Development Ecology Information Service 619 Upland Place, Alexandria, VA 22301, USA 703836

Fowler R., and Rockstrom J., 2001. Conservation tillage for sustainable agriculture: An agrarian revolution gathers momentum in Africa. Regional Land Management Unit (RELM), P.O Box 63403, Nairobi, Kenya.

Gereta E.J, 2004. The importance of water quality and quantity in the tropical systems, Tanzania. Tanzania National parks, Dodoma Road, P.O Box 3134, Arusha, Tanzania.

GESAMP -IMO/FAO//UNESCO/IOC/WMO/WHO/IAEA/UN/UNEP Joint Group of Experts on the Scientific aspects of Marine Environment Protection, Protecting the Oceans from land-based activities-Land based sources and activities affecting the quality and uses of marines, coastal and associated freshwater environment. 2001, UNEP. p. 159 pp.

Hakan Tropp, 2007. UNDP. Improving how we, as individuals, and as part of a collective society, govern the access to and control over water resources, and their benefits. Website: www.watergovernance.org

Hoffman, C.M. 2007. Geospatial Mapping and analysis of water availability - demand use within the Mara River Basin. Florida International University, Miami, Florida, USA. Website: www.globalwaters.net.

Kareith S. 2003; Coping with Declining Tourism, examples from communities in Kenya. Lesson sharing on pro-poor tourism. Economic and Social Research Unit (ESCOR) of the Department for International Development (DFID), UK. 
Karin H. M., Guthiga P. and Mburu J., 2008. Factors influencing local communities' satisfaction levels with different forest management approaches of Kakamega forest, Kenya. Centre for Development Research (ZEF), University of Bonn, Walter-Flex Str. 3, 53113, Bonn, Germany

Kenya Forests working group, 2006. Changes in forest cover in Kenya's five "water towers" 2003 - 2005. C/O East African Wild Life Society, P.O Box 47146 - 00100, Riara Road - Kilimani, Nairobi, Kenya.

Kenya Forests working group, 2005. Maasai Mau statsus report 2005. C/O East African Wild Life Society, P.O Box 47146 - 00100, Riara Road - Kilimani, Nairobi, Kenya.

Kenya Forests working group, 2004. Changes in forest cover in Kenya's five "water towers" 2000 - 2003. C/O East African Wild Life Society, P.O Box 47146 - 00100, Riara Road - Kilimani, Nairobi, Kenya.

Kimaru G. and Jama B. 2005. Improving land management in eastern and Southern Africa: A review of practices and policies. ICRAF Working Paper no. 18. Nairobi, Kenya. World Agroforestry Centre. Published by the World Agroforestry Centre (ICRAF) Eastern Africa Regional Programme United Nations Avenue PO Box 30677, GPO 00100 Nairobi, Kenya

Hashimoto K., 2008. Study on willingness to participate in the payment for environmental services scheme in the Mara Basin. Environmental Studies Department, Florida International University, 11200 SW 8 st, Miami, Florida, 33199.

Li Y., LeDoux C. B., Wang J., 2006. An economic assessment of implementing streamside management zones in central Appalachian hardwood forests. West Virginia Agricultural and Forestry Experimental Station. Forest Products Society.

Louisa Richmond-Coggan, 2006. Assessing Wildlife distribution and population trends in the greater Mara Ecosystems, Kenya: the synergistic effects of landscapes and threats. Durrell Institute of Conservation and Ecology, University of Kent, UK.

Mati B.M, Mutie S, Home P, Mtalo F, Gadain H, 2005. Land use changes in the transboundary Mara Basin: a threat to pristine wildlife sanctuaries in East Africa. I- Jomo Kenyatta University of Agriculture and Technology, Nairobi, Kenya. II - University of Dar es Salaam, Tanzania. III - United States Geological Survey, FEWS NET, Nairobi, Kenya.

Mbote P.K, 2005. Land Tenure, land use and sustainability in Kenya, towards innovative use of property rights in wildlife management. International Environmental Law Research Centre, International Environmental house, Chemin de Balexert 7, 1219 Chatelaine, Geneva, Switzerland (http/www.ielrc.org) 
McNeely J.A. and Scherr S.J. 2002, Forthcoming Eco-agriculture: Strategies to feed the world and save wild biodiversity: Island Press, Washington DC.

Mermunen T. 2004. Land use policy in Kenya: Experiences from Taita Taveta district. University of Helsinki, Department of Geography

Millington P, 2000. River Basin Management: Its role in major water infrastructure projects. World Commission on Dams, Thematic Review volume 3.

Ministry of Environment and Natural Resources of the government of Kenya, World Summit on Sustainable Development, Johannesburg, South Africa. August/September 2002. P. O. Box 30521, Tel. +254-2-2716103 Fax 727622, NAIROBI, KENYA

Ministry of Lands of the government of Kenya, 2007. National Land Policy Secretariat. Available online at www.fankenya.org.

Mwanyoka I. R., 2005. Payment for water services as a mechanism for watershed management: Case study of Sigi River, Tanga, Tanzania.

Nakao M., and Sohngen B., 1999. The effect of site quality on the costs of reducing soil erosion with filter strips. Department of Agricultural, Environmental, and Development Economics, Ohio State University, 2120 Fyffe Road, Columbus, OH 43210-1067.

Nature Kenya and Birdlife International, 2007. Habitats and percentage cover. P.O Box 44486 - 00100, Nairobi, Kenya. Website: http//www.birdlife.org/datazone/sites.

Ninan K. N. and Sathyapalan J., 2004. The economics of biodiversity conservation: a study of coffee growing region in the Western Ghats of India. Ecological Economics Unit, Institute for Social and Economic Change, Bangalore - 560 072, India. Available online at www.sciencedirect.com

Nicholson M., 2001. Restore the Earth Project Trees for life. The Park Findhorn Bay, Forres IV36 3TZ, Scotland.

Njuki J, Kowero G and Nair C.T.S, 2004; What shapes forestry in Africa? Forestry Department, FAO, Viale delle Terme di Caracalla, 00100 Rome, Italy. Email: cts.nair@fao.org

Nyangena W. and Kohlin G. 2008. Estimating returns to soil and water conservation investments: An application to crop yield in Kenya. Environment for Development, Discussion Paper Series 08-32. Kenya Institute for Policy and Public Research and Analysis (KIPPRA), University of Nairobi, Kenya.

O'Keeffe J, Lens P, Steveninck E.R, Dam W.A, Steen P., 2007. The environmental Integrity of water resources, UNESCO-IHE, Institute for Water Education, The 
Netherlands.

Pagiola S. 2006. Payments for Environmental Services, combining science and economics for sustainable conservation. Kathryn Fuller Science for Nature Symposium, Washington DC.

Randall Francis Kehrig, 2002 - Agricultural Practices and water quality in Saskatchewan; The Social Ecology of Resource Management.

Reis N., Sydness G. S., Barton D. N., 2007. Feasibility of Payment for Watershed Services. Part 1: A methodological review and survey of experiences in India and Asia. The Norwegian Institute for Water Research, Gaustadalleen 21, N-0349 Oslo, Norway. ISBN 978-82-577-5128-9. Website: www.niva.no

Rummer B., 2004. Managing Water Quality in Wetlands with forested Best Management Practices. USDA Forest Service, 520 Devall Drive, Auburn, Alabama 36849, USA. Also available online from; www.springerlink.com/content/v60664w0wh712126/fulltext.pdf

Sadoff C. W. and Grey D., 2005. Cooperation on International Rivers, a continuum for securing and sharing benefits. International Water Resources Association, Water International, Volume 30, Number 4.

Spash C. L., Stagl S. and Getzner M., 2005. Alternatives for Environmental Valuation. London: Routledge

Swinkels R. A., Franzel S., Shepherd K. D., Olhsson E., and Ndifa J.K., 1996. The Economics of Short Rotation Improved Fallows: Evidence from Areas of High Population Density in Western Kenya. International Centre for Research in Agroforestry (ICRAF), P.O Box 30677, Nairobi, Kenya.

Tambang Y. G., and Svensson M.G.E., Low external input strategies for sustainable small-scale farming in Kenya. A systems dynamic approach. Lund University centre for sustainability studies, LUCSU, Lund University, P.O Box 170, SE-221 00 Lund, Sweden.

Tamubula I., and Sinden J.A., 1999. Sustainability and economic efficiency of agroforestry systems in Embu, Kenya: An application of environmental modeling. Department of Agriculture, Institute of Teacher Education, Kyambogo, Makere University, Kampala, Uganda. Available online at www.elsevier.com/locate/envsoft

Technical Reference for Maryland's Tributary Strategies, 2003: Documentation for Data Sources and Methodologies Used in Developing Nutrient Reduction and Cost Estimates for Maryland's Tributary Strategies.

Website; (http://www.dnr.state.md.us/bay/tribstrat/tsdw/technical reference.pdf)

Tenge A.J., De graaff J., and Hella J.P., 2005. Financial efficiency of major soil and 
water conservation measures in West Usambara highlands, Tanzania. Department of Agricultural Economics, Sokoine University of Agriculture, P.O Box 3003, Morogoro, Tanzania. Available online at www.sciencedirect.com.

Wayne F. Ching, 2001. Department of Land and Natural Resources. Division of Forestry and Wildlife. 1151, HI, 96813. Website: http//www.state.hi.us.

WWF, 2005. Mara River basin Integrated Water Resources Program, Eastern Africa Regional Programme Office - EARPO, Nairobi, Kenya

WWF, 2006. Payments for Environmental Services an equitable approach to reducing poverty and conserving nature, Gland, Switzerland.

Wunder S, 2005. Payment for Environmental services: Some nuts and bolts. BY the Center for International Forest Research. ISSN 0854-9818@2005. Website: http:cifor.cgiar.org

WWF, 2009. Managing the Mara River in Kenya and Tanzania. Eastern Africa Regional Programme Office, $5^{\text {th }}$ Floor of ACS Plaza, Lenana Road, P.O Box $62440-00200$, Nairobi, Kenya.

Wunder S., and Southgate D., 2007. Paying for watershed services in Latin America: A review of current initiatives. Sustainable Agriculture and natural Resource Management Collaborative Research Support Program. Office of International Research, Education, and Development (OIRED), Virginia Tech. Available online at. www.oired.vt.edu

Wunder S. 2008. Payment for environmental services and the poor: concepts and preliminary evidence. Centre for International Forestry Research (CIFOR). Environment and Development Economics. Cambridge University Press, United Kingdom. 


\section{APPENDIX ONE}

\section{SURVEY QUESTIONAIRE}

As part of my Masters thesis research, I am conducting a survey for an economic assessment of Best Management Practices in the Mara River basin. Results of this study will be used for improvement of agricultural practices, farmer's relationships and implementation of practices that will be beneficial to the farmers, natural resource managers, the tourism and the NGO sector. The results will be made available to the Mara River Basin community, academic institutions and all stakeholders.

I kindly request you to complete the following questionnaire that I am using to collect information for this study. No information obtained in relation to this study will be identified with you and will remain confidential. In all written reports and publications, only group data will be presented.

Thank you so much for your cooperation.

George Atisa

Part A.

Village/Town:

District:

1. Respondent number

2. Gender

Male

Female

3. Age (respondednt).

4. Acquired Educational Level

No schooling

Primary school

High School

College/University

5. What are your main sources of family income?
I. Farming ( Sale of farm produce)
III. Livestock Keeping
II. Livestock Keeping
IV. Other (Specify

6. Your Households monthly income in Kenya shillings

$$
\begin{aligned}
& \text { Below } 1,000 \\
& \text { etween } 3001-6000 \\
& \text { Between } 1001 \text { - } 3000 \\
& \text { Over } 6,000
\end{aligned}
$$

7. Ownership of the land you are farming Purchased Leased

Other

8. How long have you stayed here in years

Less than 2

Between 5-8
Between $2-5$

Over 8

9. What is the size of your Farm in acre or hectares? 
10. What was the cost of the land you

Are farming when you purchased it on in Kenya shillings?

Part B. Farming

For the following statements, please indicate the extent of your agreement or disagreement by cycling your choice.

11. You are a large-scale commercial farmer , small-scale commercial farmer, OR a subsistence farmer (please choose one)

12. Most farmers in the Mara River Basin have migrated here from other places
1. I strongly disagree
2. I disagree
3. Undecided
4. I agree 5. I strongly agree

13. Human population in the Mara River Basin is growing rapidly

1. I strongly disagree 2 . I disagree 3 . Undecided 4 . I agree 5. I strongly agree

14. Areas of steep slope should remain under forest cover and protected
1. I strongly disagree
2. I disagree
3. Undecided
4. I agree 5. I strongly agree

15. Deforested areas must be reforested urgently
1. I strongly disagree
2. I disagree
3. Undecided
4. I agree 5. I strongly agree

16. You are a direct beneficiary or user of the water from the Mara River and/or its tributaries.
1. I strongly disagree
2. I disagree
3. Undecided
4. I agree 5. I strongly agree

17. Measures should be taken to protect the Mara water catchment area.
1. I strongly disagree
2. I disagree
3. Undecided
4. I agree 5. I strongly agree

18. Commercial and mechanized agriculture should be restricted in the Mara river Basin
1. I strongly disagree
2. I disagree
3. Undecided
4. I agree 5. I strongly agree

219. Irrigation farmers should pay for water used from the Mara river
1. I strongly disagree
2. I disagree
3. Undecided
4. I agree 5. I strongly agree

20. Irrigation farming is drawing so much water and leaving very little in the river to flow downstream.
1. I strongly disagree
2. I disagree
3. Undecided
4. I agree
5. I strongly agree

21. Irrigation farming should not be encouraged in the Mara River Basin.
1. I strongly disagree
2. I disagree
3. Undecided
4. I agree
5. I strongly agree 
Part C. Water and Environmental Quality

22. Quality of water downstream the river has been deteriorating in recent years.

1. I strongly disagree 2 . I disagree 3 . Undecided 4 . I agree 5 . I strongly agree

23. Farmers are not investing in water resources in the Mara River

1. I strongly disagree 2 . I disagree 3 . Undecided 4 . I agree 5 . I strongly agree

24. Quality of water in the Mara River is still good.

1. I strongly disagree 2 . I disagree 3 . Undecided 4 . I agree 5 . I strongly agree

25. I use chemical fertilizers on my farm

1. I strongly disagree 2 . I disagree 3 . Undecided 4 . I agree 5 . I strongly agree

Part D. COST OF IMPLEMENTING BMPs.

26. What proportion of your farm is under cultivation?

27. Do you use Fertilizers? Yes __ NO.

28. If you use fertilizers, how much per hectare or acre

29. Does your land border any river?. Yes _ No

30. Are you willing to leave a portion of your land next to the river as a buffer to protect the river?.

Yes No.

31. Are you willing to implement Best Management Practices?. Yes.

32. Is there a lot of soil erosion on your farm?.

33. (a) If yes, are you doing anything to control it?

(b) What are you doing?, please explain.

Yes. No. No.

Yes. No.

Part E. BEST MANAGEMENT PRACTICES

34. I understand the benefits of best management practices (BMPs)

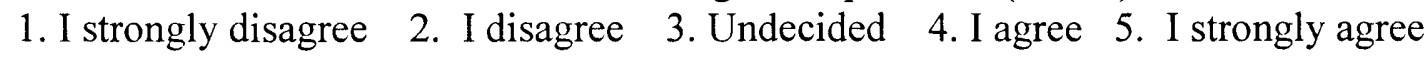

35. Best Management Practices (BMPs) will lead to significant improvements in agricultural returns.

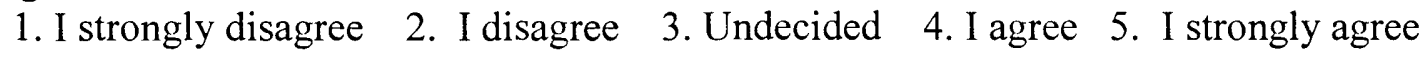

36. I am willing to implement BMPs on farm at my own cost.

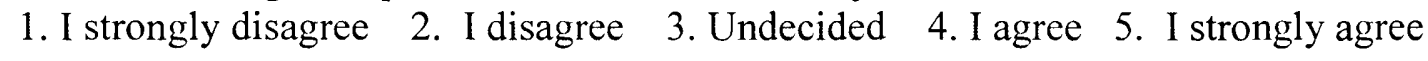

37. Implementation of BMPs should be financed

1. I strongly disagree 2 . I disagree 3 . Undecided 4 . I agree 5 . I strongly agree 
38. Total ban of settlements on the catchment is not a good idea

1. I strongly disagree 2 . I disagree 3 . Undecided 4 . I agree 5 . I strongly agree

39. Mixed farming of crops and forests is a good best management practice
1. I strongly disagree
2. I disagree
3. Undecided
4. I agree 5. I strongly agree

40. I have soil erosion controls on my farm
1. I strongly disagree
2. I disagree
3. Undecided
4. I agree 5. I strongly agree

41. Soil erosion is a big problem for farmers in the Mara

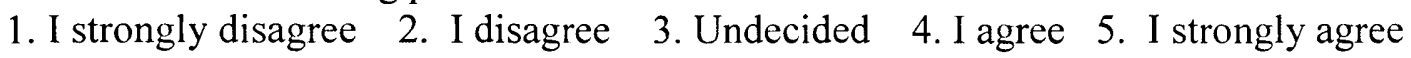

42. (a). How would you rank the following Best Management Practices for use on your farm on a scale of 1 to 5 for water quality protection, economic considerations and technical suitability:

Where:

$1=$ Not suitable, $2=$ Least suitable, $3=$ Average, $4=$ suitable, $5=$ Most suitable

i. water quality economically technically

$\begin{array}{llll}\text { ii. } & \text { Contour farming.............. } & - & -\end{array}$

43 (b). Please explain briefly why you rank these practices the way you did in the order as given above

i. 
ii.

iii.

iv.

v.

vi.

vii.

viii.

ix.

X.

xi. 
xii.

xiii.

44. How many of these BMPs would you be willing to implement on your farm?

45. What is your estimated cost of BMPs that you said you may implement on your farm?

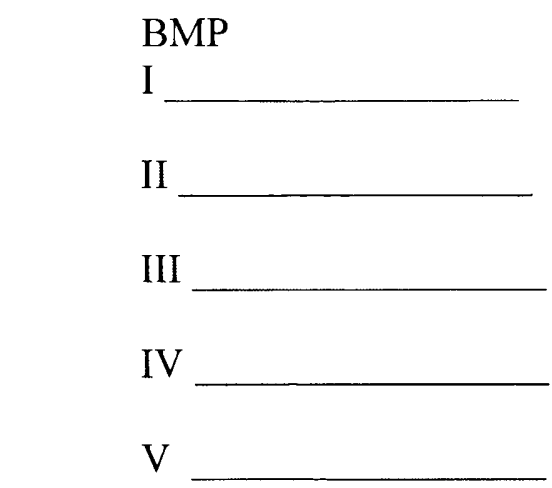

Cost (KSh/hectare?)
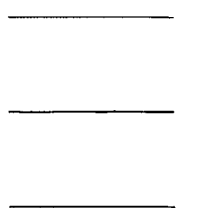

46. What is your criteria of arriving at such a cost?

I.

II.

III.

IV.

$\mathrm{V}$.

47. Declining water quality in the Mara River and its tributaries can be attributed to degradation of forests and pastures on public or common lands in your area.

1. I strongly disagree 2 . I disagree 3 . Undecided 4 . I agree 5 . I strongly agree

48. Suppose the government or non-governmental community organizations decide to implement best land management practices on public lands (such as re-forestations, pasture management, river buffer zone protection, etc.). The success of such projects depends on community participation and cooperation.

(a) Would you be willing to work [X] __ day/s per week for free for such public land protection projects in your area? 
[Interviewer: choose $0.1,0.25,0.5,1,2$, or 3 days/week at random as value of $[\mathrm{X}]$ above. Make sure to choose each value roughly equal number of times in the sample. That is, in a sample of 240 households, you would choose each value 40 times]

(b) What are some of the reasons you said "Yes" or "No" to the above question:

\section{$\underline{\text { Reasons for "YES" Answer }}$}

It is our moral responsibility to take care of our common land So that we can leave a healthy environment for our future generations I benefit from a healthier environment (e.g., such as more wood, grass, and wildlife) This will benefit people living downstream I can afford the time easily Other reasons

Reasons for "NO" Answer I cannot afford spending that time I don't gain directly anything from this effort The government should take care of this problem I cannot trust that government or outside agencies to do this kind of project I don't want the government or any other agencies to meddle with our life Others:

(c) If you answer to (a) is "NO", would you participate in such projects if compensated? YES NO

(d) What is the daily wage rate in your area? KSh /day

49. (a) Do you sell your harvest: Yes.

No.

(b) What is your income per hectare:

Ksh.

50. Do you get good income per hectare:

Yes.

No.

51. How much water do you use per hectare or acre per year in litres: ..

52. What is the cost of irrigation water per hectare?:

53. What is the cost per hectare from cultivation to harvest?... 
54. What alternatives do you have besides farming, please explain.

55. I understand the Meaning of Payment for watershed services Yes. No.

56. Farmers can organize themselves and generate internal funding to pay for the cost of implementating BMPs.

1. I strongly disagree $\quad 2$. I disagree 3 . Undecided 4 . I agree 5 . I strongly agree 57. Upstream Farmers can accept to implement BMPs if they are compensated for doing so by downstream farmers.

1. I strongly disagree 2 . I disagree 3 . Undecided 4 . I agree 5 . I strongly agree

58. Downstream farmers will accept to compensate upstream farmers to implement BMPs that will ensure good quality and quantity of water in the Mara river
1. I strongly disagree
2. I disagree
3. Undecided
4. I agree 5. I strongly agree

59. What would be the most sustainable, acceptable and least cost source of funding to pay for the cost of implementing BMPs, please tick on one.

I. Government funding

II. Compensation from downstream water users

III. International NGOs

IV. Self.

60. List any support you would like to receive in order to effectively implement all the Best Management Practices you need on your farm. 